\title{
Nicaragua: Enhanced Initiative for Heavily Indebted Poor Countries- Completion Point Document
}

This paper was prepared by staff of the International Monetary Fund and the World Bank in connection with the Executive Board's consideration of Nicaragua's progress under the Enhanced Initiative for Heavily Indebted Poor Countries. It is based on the information available at the time it was completed on January 6, 2004. The views expressed in this document are those of the staff team and do not necessarily reflect the views of the government of Nicaragua or the Executive Board of the IMF.

The policy of publication of staff reports and other documents by the IMF allows for the deletion of market-sensitive information.

To assist the IMF in evaluating the publication policy, reader comments are invited and may be sent by e-mail to publicationpolicy@imf.org.

Copies of this report are available to the public from

International Monetary Fund $\bullet$ Publication Services

700 19th Street, N.W. • Washington, D.C. 20431

Telephone: (202) 6237430 • Telefax: (202) 6237201

E-mail: publications@imf.org •Internet: http://www.imf.org

Price: $\$ 15.00$ a copy

\section{International Monetary Fund Washington, D.C.}




\section{INTERNATIONAL MONETARY FUND AND \\ INTERNATIONAL DEVELOPMENT ASSOCIATION}

\section{NICARAGUA \\ Enhanced Heavily Indebted Poor Countries (HIPC) Initiative Completion Point Document}

Prepared by the Staffs of the International Monetary Fund and International Development Association ${ }^{1}$

January 6,2004

Contents

Page

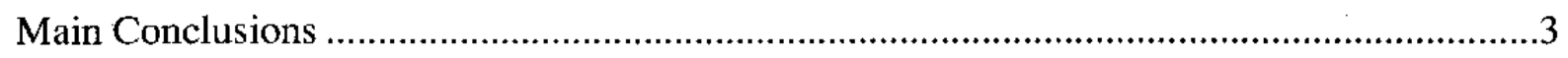

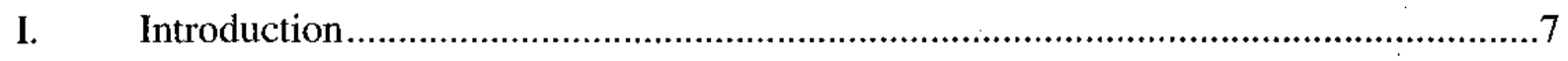

II. Assessment of Requirements for Reaching the Completion Point .................................... 8

A. Poverty Reduction Strategy Paper and HIPC Tracking

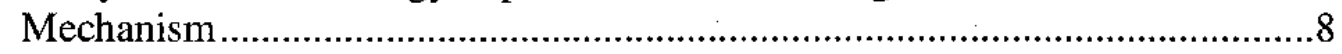

B. Use of Savings from HIPC Interim Relief ........................................................

C. Macroeconomic Performance in 2001-03 .....................................................10

D. Human Capital Development and Social Protection ............................................11

E. Strengthening Governance..............................................................................13

F. Implementation of Pension Reform ...........................................................16

G. Divestiture of Public Utilities ...........................................................................18

III. Debt Sustainability over the Medium Term............................................................2

A. Data Reconciliation and Revision of Assistance ………......................................21

B. Updated Debt Sustainability Analysis ..............................................................23

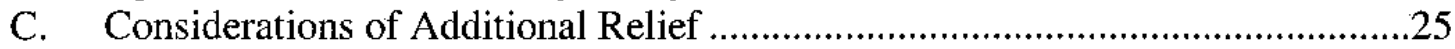

D. Sensitivity Analysis and Long-Term Debt Sustainability ....................................27

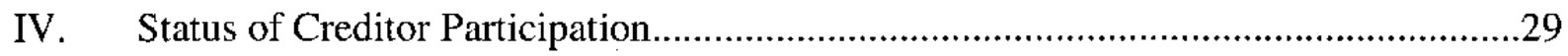

A. Multilateral Creditors .................................................................................

B. Bilateral and Commercial Creditors .............................................................31

\footnotetext{
${ }^{1}$ Approved by Markus Rodlauer and G. Russell Kincaid (IMF), and David De Ferranti and Gobind T. Nankani (IDA).
} 


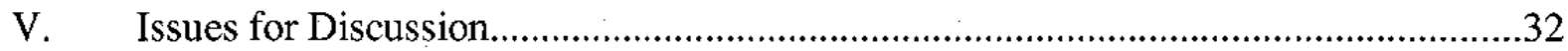

Boxes

1. Status of Poverty Reduction and Structural Measures for Reaching the Enhanced HIPC Initiative Floating Completion Point ............................................................34

2. Selected Social and Demographic Indicators ............................................................

3. Total and Poverty-Reducing Expenditures ...................................................................

Figures

1. External Debt and Debt-Service Indicators for Medium- and Long-Term

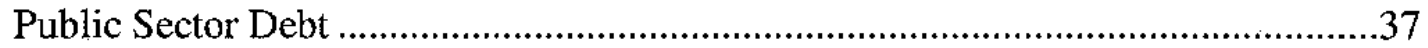

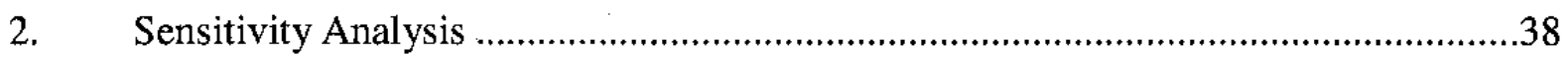

Tables

1. Medium- and Long-Term Macroeconomic Framework ..............................................39

2. Medium- and Long-Term Balance of Payments .........................................................40

3. Nominal and Net Present Value of External Debt Outstanding as of

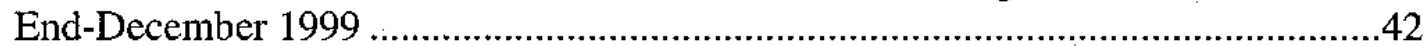

4. Estimated Assistance at Decision Point (Amended) ...............................................43

5. External Public and Publicly Guaranteed Debt at End-December 2002 .....................44

6. Comparison of Discount Rate and Exchange Rate Assumptions .................................45

7. Comparison of Net Present Value of External Public Debt Between Decision and Completion Point .............................................................................46

8. Net Present Value of External Debt ...............................................................................4

9. External Debt Service After Full Implementation of Debt-Relief

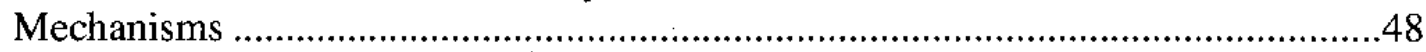

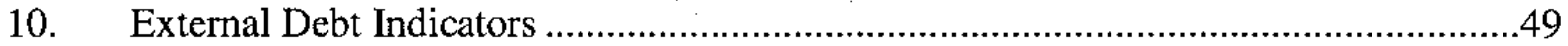

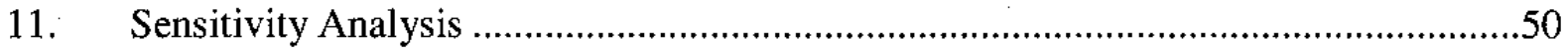

12. Status of Creditor Participation Under Enhanced HIPC Initiative .............................51

13. Delivery of IDA Assistance Under the Enhanced HIPC Initiative ...............................53

14. Delivery of IMF Assistance Under the HIPC Initiative............................................54

15. Paris Club Creditors' Delivery of Debt Relief Under Bilateral Initiatives Beyond the Enhanced HIPC Initiative ..................................................55

16. HIPC Initiative: Status of Country Cases Considered Under

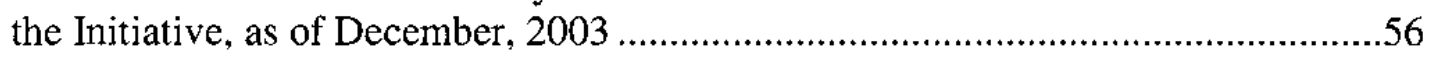

Appendices

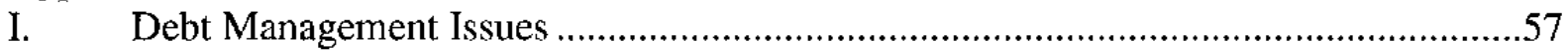

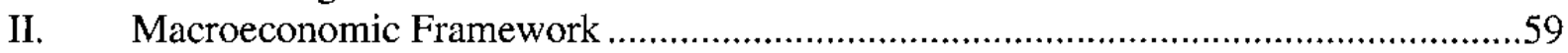

III. Public Sector Debt Sustainability and Creditor Negotiations .......................................60 


\section{Main Conclusions}

- The staffs of the IMF and IDA consider that Nicaragua has met all but one of the conditions for reaching the completion point under the enhanced Heavily Indebted Poor Countries (HIPC) Initiative, as specified in the decision point document. A waiver is recommended for the unmet measure, which refers to the divestiture of all the generating units of the power utility. Nicaragua's macroeconomic program is on track, as evidenced by satisfactory performance under the PRGF arrangement, and the government has made significant progress in implementing its structural adjustment program, although with some delays. The JSA of the second annual PRSP Progress Report considers that, despite a difficult political and economic environment, important progress has been made in the implementation of the PRSP, which was prepared in broad consultation with civil society and the donor community, and that these efforts provide sufficient evidence of the government's continuing commitment to poverty reduction.

- The interim relief provided under the enhanced HIPC Initiative has allowed Nicaragua to increase social spending significantly in recent years. With the progress made in implementing an integrated financial management system and revisions in the budget format, Nicaragua has strengthened substantially the tracking of poverty-reducing expenditures. With these improvements, the staffs consider that the Poverty Reduction Strategy Paper (PRSP) and the mechanism for tracking poverty-reducing expenditures provide a solid basis for monitoring the use of the total assistance provided to Nicaragua for poverty reduction, including the assistance provided under the enhanced HIPC Initiative.

- The debt data reconciliation exercise confirmed the decision point data for multilateral creditors, but warranted a revision of the debt owed to some bilateral and commercial creditors. There has also been a minor revision of the export figures for 1997, which warrants a downward adjustment of US\$16 million in the three-year average of Nicaragua's exports of goods and nonfactor services during 1997-99. The staffs recommend that the debt relief under the enhanced HIPC Initiative be amended to take into account these data revisions. The additional assistance to Nicaragua required to bring down the net present value (NPV) of debtto-exports ratio as of end-1999 to 150 percent amounts to US\$41 million.

- According to the revised DSA, Nicaragua's NPV of external debt-to-exports ratio, after enhanced HIPC assistance and additional bilateral debt relief, at end-2002 is 11 percentage points higher than projected at the time of the decision point. Numerous factors contributed to the deterioration of the debt ratio. The largest factors are the deterioration of export prices and the decline in discount rates used to calculate the NPV of debt, although the accumulation of arrears during the interim period also played a part. Nonetheless, with the debt reduction to be provided under the enhanced HIPC Initiative (as amended in light of the findings of 
the data reconciliation exercise) and on a voluntary basis by Paris Club creditors, Nicaragua's prospects for achieving external debt sustainability are good, but will require a continuation of prudent policies such as those currently in place. The staffs consider that Nicaragua does not meet the criteria justifying additional assistance at the completion point.

- $\quad$ Achieving debt sustainability will require a continued fiscal consolidation and a prudent borrowing policy. The rapid increase in the public domestic debt in recent years has been a cause for concern. To address this problem, the government is implementing reforms to strengthen the financial sector, whose weakness has been the main cause for the recent increase in domestic debt, and the national assembly has approved a public debt law that establishes a centralized process for contracting public sector debt with a view toward long-term sustainability. Also, the government is committed to maintain prudent fiscal policies, while limiting its external financing sources to grants and highly concessional credits.

- The staffs of the IMF and IDA recommend the Executive Directors to determine that the conditions for reaching the completion point under the enhanced HIPC Initiative have been met. 


\section{Abbreviations and Acronyms}

\begin{tabular}{ll} 
BCN & Central Bank of Nicaragua \\
BCP & Basel Core Principles \\
BRB & Bank resolution bond \\
CABEI & Central American Bank for Economic Integration \\
CAFTA & Central American Free Trade Area \\
CDs & Certificates of Deposit \\
CPS & Combined Public Sector \\
DC & Defined Contribution \\
DGA & General Directorate of Customs \\
DGJ & General Directorate of Internal Revenue \\
DISNORTE & Electricity Distribution Company (Northern) \\
DISSUR & Electricity Distribution Company (Southern) \\
DSA & Debt sustainability analysis \\
EFA & Education for All \\
ENACAL & Nicaraguan Water and Sewerage Company \\
ENEL & Nicaraguan Electricity Company \\
ENITEL & Nicaraguan Telecommunications Company \\
ENTRESA & Transmission Company \\
FISE & Emergency Social Investment Fund \\
FITEL & Investment Fund for Telecommunications \\
FOCEM & Fondo Centroamericano de Estabilización Monetaria \\
FOGADE & Deposit Guarantee Fund \\
FSAP & Financial Sector Assessment Program \\
FSS & Social Supplementary Fund \\
GECSA & Electricity Generation Company \\
GEMOSA & Electricity Generation Company \\
GEOSA & Electricity Generation Company \\
HIDROGESA & Electricity Generation Company \\
HIPC & Heavily Indebted Poor Countries \\
IBRD & International Bank for Reconstruction and Development \\
IDA & International Development Association \\
IDB & Inter-American Development Bank \\
IDR & Rural Development Institute \\
IFAD & International Fund for Agricultural Development \\
INE & Nicaraguan Energy Regulatory Institution \\
INIFOM & Nicaraguan Institute of Municipal Development \\
INIM & Nicaraguan Women's Institute \\
INSS & Nicaraguan Social Security Institute \\
JSA & Joint Staff Assessment \\
MAGFOR & Ministry of Agriculture \\
MARENA & Ministry of the Environment and Natural Resources \\
MDG & Millennium Development Goals \\
MEGATEL & Honduran/Swedish Consortium \\
& \\
\hline
\end{tabular}


MFD

MHCP

MIFAM

MIFIC

MINSA

MITRAB

MTI

NDF

NDP

NIR

NPL

NPV

PAYG

PETRONIC

PLC

PRGF

PRSC

PRSP

PSIA

SB

SECEP

SMEFP

SMP

TA

TELCOR

UNCTAD/DMFAS

USAID

VAT
Monetary and Financial Affairs Department

Ministry of Finance

Ministry of the Family

Ministry of the Economy

Health Ministry

Ministry of Labor

Ministry of Transportation and Infrastructure

Nordic Development Fund

National Development Plan

Net international reserves

Nonperforming loans

Net present value

Pay-as-you-go

Petroleum Distribution Company

Partido Liberal Constitucionalista

Poverty Reduction and Growth Facility

Poverty Reduction Support Credit

Poverty Reduction Strategy Paper

Poverty and Social Impact Assessment

Superintendency of Banks

Secretariat of Coordination and Strategy of the Presidency

Supplementary Memorandum of Economic and Financial Policies

Staff-Monitored Program

Technical Assistance

Nicaraguan Telecommunications Regulatory Institution

United Nations Conference on Trade and Development/Debt

Management and Financial Analysis System

U.S. Agency for International Development

Value-added tax 


\section{INTRODUCTION}

1. This paper assesses the progress of Nicaragua under the enhanced HIPC Initiative and seeks approval of the Boards of the completion point under the Initiative. In December 2000, the Boards of the IMF and IDA agreed that Nicaragua had met the conditions for the decision point. The debt relief approved at that time amounted to US $\$ 3.3$ billion in NPV terms, the largest amount approved until that time, and was calculated to bring Nicaragua's debt to 150 percent of exports. That relief entailed a reduction of 72.2 percent of the NPV of Nicaragua's debt after full application of traditional debt relief mechanisms, as estimated in the decision point document. Based on proportional burden sharing, the amount of debt relief contributed by IDA/IBRD amounted to US\$189 million, while that of the IMF amounted to US\$82 million. A revision of the DSA presented in the decision point document is made in the present document. It incorporates new information received during the interim period and corrections on the calculation of the stock of outstanding debt, as well as revisions of the exports of goods and nonfactor services for 1997-99. All the revisions made to the decision point DSA would result in an increase of the assistance under the enhanced HIPC Initiative of US\$41 million. The IDA/IBRD's share would rise by US $\$ 2$ million, and that of the IMF by US $\$ 1$ million.

\section{During 2001-03, Nicaragua received US\$195.5 million in HIPC interim .} assistance from multilaterals, including US\$22.2 million from IDA and US\$3.6 million from the IMF. The Inter-American Development Bank (IDB) and the Central American Bank for Economic Integration (CABEI) provided HIPC interim assistance of US\$94.9 and US\$71.7 million, respectively. Interim relief from the Paris Club and those non-Paris Club official bilateral creditors with whom Nicaragua has signed agreements, delivered via a Cologne flow operation or in a stock operation on comparable terms, totaled US\$57.6 million during the same period.

\section{In September 2001, the Boards of IDA and the IMF endorsed Nicaragua's} Strengthened Economic Growth and PRSP as a basis for concessional assistance from the IMF and IDA. The first annual progress report for the PRSP and the accompanying Joint Staff Assessment (JSA) were discussed by the Boards in November 2002, and a second annual progress report and JSA are being considered at the same time as this document. The Board of the IMF will discuss the staff report for the fourth review of the PRGF-Supported Program along with these documents, while the Board of IDA will also discuss the first Poverty Reduction Support Credit (PRSC) for Nicaragua.

\section{This paper recommends that the Boards approve the completion point for} Nicaragua under the enhanced HIPC Initiative. In addition to the PRSP, the measures set out in the decision point document for reaching the completion point encompass macroeconomic, structural, and social-sector reforms. In the staffs' opinion, Nicaragua has completed or made substantial and satisfactory progress on all but one of these measures and successfully completed the first year of program implementation under the Poverty Reduction and Growth Facility (PRGF), despite a difficult political and economic environment. A waiver is recommended for the unmet condition (see below). 
5. The remainder of this document is organized as follows: Section II assesses Nicaragua's performance in meeting the conditions for reaching the completion point. Section III presents the updated DSA, including sensitivity tests. Section IV discusses the status of creditor participation. Section V presents issues for discussion.

\section{ASSESSMENT OF REQLiREMENTS for REACHING THE COMPLETION POINT}

6. The policy and reform conditions for reaching the completion point were met by end-2003, except for one condition pertaining to the divestiture of the generating units of the power utility, for which a waiver is recommended (Box 1). The conditions for reaching the floating completion point under the enhanced HIPC Initiative are established in Box 6 of the decision point document (www.imf.org and IDA/R2000-237). ${ }^{2}$ These conditions call for compliance with the following measures: (i) preparation of a fully participatory Poverty Reduction Strategy Paper (PRSP) and its satisfactory implementation for at least one year as evidenced by the staff assessment of the country's annual progress report; (ii) use of budgetary savings resulting from the interim relief under the enhanced HIPC Initiative in accordance with the proposals set out in Appendix III of the decision point document (which addresses the tracking of poverty-related public expenditures through the Social Supplementary Fund, (FSS); (iii) maintenance of a stable macroeconomic framework and satisfactory performance under a program supported by a PRGF arrangement;

(iv) implementation of reforms to promote human capital development and social protection; (v) implementation of governance strengthening measures; (vi) implementation of remaining actions needed to introduce a satisfactory pension system of funded, private sector-managed and individual accounts, and (vii) divestment of the telecommunications company, ENITEL, and of all electricity generating units of the power utility, ENEL. This section discusses Nicaragua's progress toward meeting these conditions.

\section{A. Poverty Reduction Strategy Paper and HIPC Tracking Mechanism}

7. In the staff' view, Nicaragua has complied with the first floating completion point condition calling for the preparation of a fully participative PRSP and its satisfactory implementation for at least one year as evidenced by the JSA of the country's annual progress report presented to the Boards of the IMF and IDA. The PRSP was completed in August 2001, and two annual PRSP progress reports have been issued since then (in October 2002 and November 2003). Both progress reports provide a balanced review of PRSP implementation and of the advances made toward achieving the Millennium Development Goals (MDG). ${ }^{3}$ These documents are products of a wide-ranging

\footnotetext{
${ }^{2}$ The conditions in Box 6 of the decision point document are reproduced in Box 1 of this document.

${ }^{3}$ Box 2 lists selected social and demographic indicators.
} 
consultation process including the government, members of civil society and the donor community. Board approval of the JSA of the second annual PRSP progress report will assure compliance with this completion point condition.

\section{B. Use of Savings from HIPC Interim Relief}

8. The use of budgetary savings resulting from the interim debt relief under the enhanced HIPC Initiative, as reported in the annual PRSP progress reports, is in accordance with the proposals set out in Appendix III of the decision point document (second floating completion point condition). The authorities have developed an expenditure-tracking mechanism that adequately monitors the use of budgetary savings resulting from the interim relief under the enhanced HIPC Initiative. The proposals in Appendix III of the decision point document identify the Supplementary Social Fund (FSS) as the entity responsible for monitoring the use of HIPC debt relief and indicate that the use of those funds will be reflected in the central government budget, which is to identify the government's total poverty-related outlays. ${ }^{4}$ Under the current system for tracking HIPC debt relief, the Central Bank of Nicaragua calculates the total budgetary savings from HIPC debt relief for each year. ${ }^{5}$ This information is incorporated into the statistical annex of the central

\footnotetext{
${ }^{4}$ The government had initially considered channeling the entire budgetary savings from HIPC debt relief through the FSS in the central government budget; see "Reglamento Operativo FSS-HIPC", dated September 2002 and approved by the FSS Coordinating Council on September 23, 2002 (Acta No. 19). Since then, the authorities have decided against channeling the HIPC funds through the FSS, as it would unnecessarily complicate the budget presentation, even though the FSS remains responsible for monitoring the use of these funds. The authorities have revised the FSS operating regulations accordingly; see Reglamento Operativo del Fondo Social Suplementario approved by the Consejo Coordinador on November 27, 2003.

${ }^{5}$ The central bank has been calculating the budgetary savings from HIPC debt relief in each year as either (i) the difference between the average debt service paid by the government during 1992-98 (which represents an estimate of the country's capacity to service the external debt) and the actual debt service paid after the provision of HIPC interim relief, or (ii) the total debt relief provided by the multilateral organizations; whichever is higher. The authorities have agreed to revise their method of calculation in line with World Bank recommendations made in the Nicaragua Public Expenditure Review, by allowing the country's debt service capacity, as measured by the average debt service paid by the government in 1992-98, to grow at the same rate as GDP. Therefore, beginning in 2005, the budgetary savings from HIPC debt relief will be calculated as the difference between this revised estimate of debt servicing capacity and the actual debt service coming due after the provision of HIPC debt relief at the completion point. Only in 2005 would the two methodologies have begun to differ significantly.
} 
government budget, which is presented to the national assembly in October of each year. All central government expenditures and transfers associated with the poverty-reducing programs identified in the PRSP are tagged in the budget. The budget also specifies all other external and internal sources of financing of those programs. With this information, it is possible to verify whether the addition of external resources dedicated to poverty-reducing activities (including HIPC debt relief) has resulted in additional spending on povertyreducing programs by an equal amount, or has freed up domestic resources that were used for other purposes. According to the revised FSS operating regulations, the proceeds from HIPC debt relief are to be audited by the comptroller's office as part of its normal working plan of internal audits for all public institutions, which is the appropriate approach. The comptroller's office is not currently performing these audits in a comprehensive manner, however, and needs to be strengthened accordingly.

9. The budgetary savings from HIPC interim relief have contributed to significant additional spending on poverty reducing programs. This is shown in the last column of Table 10 in the government's second annual PRSP progress report, which indicates that the total adjusted spending on poverty-reducing programs (adjusted to exclude programs associated with post-hurricane Mitch reconstruction) increased by a cumulative US\$165 million during 2001-03. At the same time, domestically financed primary spending on programs not related to poverty reduction (and excluding interest payments) declined by US $\$ 49.5$ million (Box 3). The total increase in external resources dedicated to poverty reducing spending increased by US $\$ 367$ million, of which US $\$ 235$ million represents HIPC interim relief. A significant portion of those resources were used to finance increased domestic debt service and strengthen the central bank's reserve position, which was urgently needed in light of Nicaragua's extremely fragile macroeconomic situation during this period. Indeed, restoring macroeconomic stability is essential for restoring growth and achieving sustained poverty reduction.

\section{Macroeconomic Performance in 2001-03}

10. The program supported by the PRGF has been on track throughout 2003, thereby complying with the third floating completion point condition that calls for maintenance of a stable macroeconomic framework and satisfactory performance under a PRGF-supported arrangement. Quarterly reviews have fostered close cooperation between the IMF and Nicaragua during 2003, and completion of the fourth review of the program supported by the PRGF constitutes compliance with this condition.

11. After reaching the decision point in $\mathbf{2 0 0 0}$, Nicaragua faced a series of shocks, with an initially weak policy response. In addition to the destruction left behind by hurricane Mitch (1998), the economy faced the collapse of coffee prices in 2000 (the country's largest export); a banking crisis (2000-01); and a sharp decline of confidence related to the 2001 electoral process. At the same time, real GDP growth slowed from its peak in 1999 as the post-hurricane reconstruction boom associated with the hurricane came to an end. However, the government was unable to rein in public spending, contributing to 
widening fiscal and external deficits. An IMF staff monitored program (SMP) in late 2001 was unsuccessful, because the government was unable to pursue adjustment policies in the run-up to the presidential elections. In 2001, the deficit of the combined public sector (CPS) (after grants) reached 9 percent of GDP and the current account deficit widened to 24 percent of GDP, which contributed to a sharp decline in NIR (by US $\$ 170$ million).

12. The new government that took office in early 2002 moved quickly to address the large imbalances in the economy. Spending unrelated to poverty was reduced, the first round of a comprehensive tax reform was implemented, and the regulatory framework of the financial system was strengthened. In 2003, further progress was achieved with a prudent budget, a second round of tax reform, the sale of central bank assets acquired from failed banks, and refinancing agreements on the domestic debt. As a result of these policies, the CPS fiscal deficit (after grants) has narrowed sharply to about 3 percent of GDP in 2003, the external position has strengthened, and real GDP growth has started to recover.

13. Restoring macroeconomic stability has been an important achievement, but preserving it and delivering sustained rapid growth will be challenging. While real GDP per capita has fallen during 2001-03, prudent fiscal and monetary policies have kept inflation under control and have begun to make a dent in the debt burden, which will remain large after completion point. ${ }^{6}$ While the current account deficit has declined from 24.1 percent to 17.9 percent of GDP, this improvement is mostly attributable to rising remittances from abroad, rather than growing exports. Exports of goods declined slightly as a share of GDP during the interim period. This was mostly due to stagnation in some of Nicaragua's traditional exports, such as coffee and sugar, while other exports, particularly beef and exports from Nicaragua's free-trade zones, have grown significantly. Overall, while export performance has not been an engine of growth in the past few years, this may reflect a transition away from some highly price-sensitive commodities toward nontraditional exports. Aware that long-term poverty alleviation is only possible in the context of faster economic growth, the authorities have embarked on a program of investment and regional integration intended to improve the country's competitiveness and growth potential going forward.

\section{Human Capital Development and Social Protection}

14. The government has fully complied with all the elements of the fourth floating completion point condition, which calls for the implementation of reforms to develop human capital and social protection. Investment in human capital development represents the second pillar of Nicaragua's PRSP. This pillar focuses on investment in basic education and technical training, preventive health care at the primary level, child nutrition, and a

\footnotetext{
${ }^{6}$ The fragility of Nicaragua's debt position, including both external and domestic components, is discussed in greater detail in the IMF Staff Report for the Fourth Review under the PRGF, presented to the IMF Executive Board with this document.
} 
stronger population policy. Structural reforms in the social sectors are vital to the success of these efforts in view of budget constraints that limit total public spending, forcing the government to focus on institutional strengthening and operational efficiency gains. Government efforts have focused on two key decentralization initiatives in the education and health sectors. In education, a central element of the government's strategy for improving the delivery of quality educational services is the provision of financial and administrative autonomy to schools, with the aim of rendering them more responsive to the local communities they serve. In health, the government's strategy focuses on improved implementation of the institutional modernization process, increasing the coverage and quality of health services and on promoting behavioral changes at the household level. Accordingly, the completion point condition calls for: (i) the approval of a satisfactory school autonomy law to strengthen the legal foundation for the envisaged sector reforms, which aim to encourage, inter alia, greater parental participation in education; and (ii) the approval of a satisfactory general health law and adoption of corresponding implementing regulations to strengthen the health ministry's regulatory and normative roles and establish a solid legal framework for the sector's modernization program, granting more autonomy to hospitals and local health systems.

15. In compliance with this condition, the school autonomy law and the general health law have been approved by the national assembly and their accompanying regulations have been issued. ' Both laws and regulations are satisfactory to IDA. To implement the school autonomy law, the government trained 2,800 school council members on their responsibilities under the new law, distributed 20,000 copies of the new law to school councils and parents, and carried out a pilot program to analyze the effects of implementing the new law. Implementation of the school autonomy program, which currently comprises 45 percent of all public schools, has slowed down, as no new schools were incorporated into the autonomous regime in $2003{ }^{8}$ The authorities are planning to continue the transfer of schools into the autonomous regime in 2004, with support from a Poverty Reduction Support Credit (PRSC) and the Education for All (EFA) - Fast Track Initiative. To implement the general health law, the government introduced a results-based management system for basic health care in 25 municipalities.

\section{Better protection for vulnerable groups represents the third pillar of}

Nicaragua's PRSP. The objective of this pillar is to improve the welfare of the most vulnerable groups in society, especially households in extreme poverty that typically are not

\footnotetext{
${ }^{7}$ These laws are: Ley de Participación Educativa, No. 413, published in La Gaceta No. 56 on March 21, 2002, whose accompanying regulation (Decreto 46-2002) was published on May 23, 2002, and Ley General de Salud, No. 423, published in La Gaceta on May 17, 2002, whose accompanying regulation was published on January 10, 2003.

${ }^{8}$ The slowdown in implementation of the school autonomy program during 2003 is partly attributable to fiscal tightness.
} 
reached by more traditional, supply-oriented social programs. The relevant completion point condition calls for the adoption of an action plan to introduce an effective social protection program, based on the results of a pilot program started in 2000. The IDB, IDA, and IMF staffs concur that compliance with this completion point condition has been achieved through the cabinet approval of a draft conceptual framework for the design of a social protection policy in 2002 and the ongoing implementation of the second phase of the government's social protection net program (Programa Red de Protección Social). The first phase of the program had a significant impact on human capital creation of the extremely poor participating households, as documented by an independent impact evaluation. ${ }^{9}$ The second phase of the program, which includes the expansion of the program to cover more than 22,500 households, incorporates the lessons learned from the first phase. This program, which provides a basic platform for a social protection policy framework, includes the development of a registry of beneficiary households (which should help avoid program overlaps) and a vehicle for rationalizing other ongoing social protection programs (thereby. helping to reduce administrative costs). The government (i) has now approved a social protection policy (named "Solidaridad"), which defines strategic priorities for developing an effective safety net for the poorest and most vulnerable groups; (ii) is finalizing the classification of vulnerable groups who are eligible for social protection; (iii) is identifying the institutional adjustments needed to implement the government's social protection policy; and (iv) is revising the guidelines for applying different social protection interventions.

\section{E. Strengthening Governance}

\section{The government has fully complied with the fifth floating completion point} condition, which calls for the implementation of governance strengthening measures that encompass four areas. These areas refer to: (i) the enactment and advance in implementation of a satisfactory civil service law to, inter alia, reduce political interference in hiring and firing decisions affecting civil servants; (ii) introduction of a satisfactory system of management and inspection of public sector procurement; (iii) satisfactory progress in implementing the plan to strengthen and improve the efficiency of the comptroller's office; and (iv) approval of the laws on penal procedures and public prosecutors, and initiation of training programs and technical preparations for their implementation.

\section{A civil service reform law that is satisfactory to IDA was approved by the} national assembly on November 19,2003 . This law provides the necessary elements for implementing a new public human resource administration system. It includes provisions to: (i) differentiate career positions from political appointments in the public administration, limiting the number and nature of the latter; (ii) establish procedures for competitive hiring, merit-based performance evaluation processes, permanent training and development, and

\footnotetext{
${ }^{9}$ This evaluation was carried out by International Food Policy Research Institute under an IDB-financed contract in support of the 'Red de Protección Social' Project.
} 
transparent firing procedures for civil servants in career positions; (iii) establish the necessary institutional arrangements to administer the new civil service system including a civil service commission and a civil service unit within the ministry of finance; (iv) establish more coherent salary policies and management procedures for the public administration; and (v) regulate proper due diligence administrative procedures for conflict and disciplinary resolutions related to human resource administration.

19. The authorities have advanced in the implementation of important activities contemplated in the new civil service law. Although it was not passed until recently, the draft civil service law has been debated in the national assembly since 1999. During the past four years, the authorities have advanced the process of reform implementation in the following areas: (i) specific regulations for implementation of the civil service law have been drafted; (ii) functional and organizational analysis for human resources have been completed for seven ministries —environment and natural resources (MARENA), economy (MIFIC), finance (MHCP), transportation and infrastructure (MTI), agriculture (MAGFOR), labor (MITRAB), and the family (MIFAM), and for the decentralized Nicaraguan Women's Institute, INIM; (iii) classification procedures and guidelines for civil service posts have been prepared; (iv) studies on relevant salary markets have been completed and proposed salary tables for the public administration have been prepared; (v) 50 percent of the total positions in the central administration have been classified and related job descriptions have been elaborated; and (vi) a detailed action plan for the implementation of the new civil service law has been prepared. Given its complexity and fiscal implications, the complete implementation of the civil service reform is expected to take place gradually over several years. Key steps of this reform process will be monitored through the policy conditionality of a proposed, IDA-financed PRSC, while necessary technical assistance from the Bank is under preparation to support the government in this effort.

\section{The government has introduced a satisfactory system of management and} inspection of public sector procurement. The objective of this measure has been to improve the efficiency and transparency of the public procurement process by strengthening internal controls within key public executing agencies, strengthening the procurement units within these same agencies, and developing a regular training program in procurement management for public sector officials. The main achievements to date in the area of strengthening internal controls include: (i) the completion of an institutional analysis of the most risk-prone procurement areas in key ministries; (ii) the development of standardized project portfolios to facilitate the inspection process; (iii) the inspection of 330 procurement contracts; and (iv) the training of staff in the Office of Public Ethics, which oversees these procurement strengthening activities, in the areas of institutional analysis and procurement inspection. In the areas of procurement management, the main advances include: (i) the completion of 15 workshops on the role and efficient operation of procurement management units, their responsibilities and the general policies governing contracts procured with funding from the major multilateral agencies; (ii) the development of draft legislation to revise the existing public procurement law (approved in December 1999) and of 
corresponding new regulations; ${ }^{10}$ (iii) the development of a draft manual to guide purchases made under simplified price quotations and petty cash purchases; (iv) the installation of computer equipment in the procurement units of the Transportation and Infrastructure Ministry (MTI) and Rural Development Institute (IDR); (v) the development of information management software to follow up on the different stages of the procurement process; and (vi) significant progress in the development of a action plan to improve the procurement system in the health ministry (MINSA). While these actions constitute adequate progress for introducing a new public sector procurement system, continuing efforts are needed to conclude the reform process initiated so far, while expanding its scope to other public sector agencies.

21. The government's program to modernize the comptroller's office consists of four components. These are: (i) revision of its institutional structure; (ii) strengthening of control mechanisms; (iii) development of a staff-training program, and (iv) development of its technology infrastructure. An international consulting firm was hired in October 2003, to carry out the first component and help coordinate implementation of the action plan. Progress has been made in the implementation of the second component with the completion of the bidding process for 100 laptop computers for auditors. Also, with respect to the fourth component of the plan, the Systems and Organization Department of the comptroller's office has advanced in the compilation of information needed to develop a diagnostic of overall technology requirements.

22. The national assembly approved a new law on public prosecutors in May 2000 and a new law on penal procedures in December 2001. The new criminal procedures code calls for oral, public trials and greatly increases the transparency of administration of justice in criminal cases. It is being implemented in two phases, with the first phase having commenced in December 2002, for serious crimes that carry sentences of three years or more. The Organic Law of the Public Ministry established a new autonomous agency, the Public Ministry, responsible for bringing indictments against criminal defendants and prosecuting criminal cases. Significant progress has been made in training staff of the justice sector agencies charged with implementing the criminal justice reforms and in completing the technical preparations needed for the implementation of the new laws. New interinstitutional commissions have been created at the national and departmental levels to analyze and carry out institutional changes needed under the new laws and address legal issues that arise during their implementation. Also, judges from the criminal district courts, prosecutors from the public ministry and attorney general's office, public defenders, police investigators and private attorneys have been provided academic training in the provisions of the new law on penal procedures, as well as practical hands-on training in fulfilling their new roles under the law. Tasks still remaining include the training of judges from the local

${ }^{10}$ Passage of the revised procurement legislation is being monitored by IDA through the policy conditionality of the proposed PRSC, which calls for submission of the legislative amendments to the national assembly by October 2004 and its approval by May 2005 . 
criminal courts and the second phase of implementation of the penal procedures law, which is to begin in December 2004. In sum, however, progress to date is satisfactory in meeting the referenced completion point condition.

\section{F. Implementation of Pension Reform}

23. The government has complied with the sixth floating completion point condition, by implementing the remaining actions needed to introduce a satisfactory pension system of funded private sector-managed and individual accounts; including the passage of a law to create a supervisory authority for pension funds, the staffing of this supervisory authority, and the restructuring of the social security institute, and by committing to a roadmap for completing the pension reform. ${ }^{11}$ The reform of Nicaragua's public retirement system is intended to contain the increase of government's contingent fiscal liabilities resulting from the growing structural imbalances of the defined benefit, pay-as-you-go (PAYG) system. The reform establishes an alternative mandatory system based on a defined-contribution (DC) approach. The latter system consists of individual retirement accounts, managed by specialized private pension fund administrators. The reform, which began in 1995 with the separation of pension and survivor accounts from other social security contributions within the Social Security Institute (INSS), required the passage of legislation to create and supervise the new system, as well as the creation of the necessary regulatory and supervision structures. It also requires the identification of private pension fund administrators and the transfer of eligible contributors that are currently in the public system to the private system, with recognition of rights acquired under the old system. Finally, in parallel with the introduction of the new retirement system and to reduce longerterm risks to fiscal stability, the reform contemplates parametric reforms (including eligibility requirements, contribution rates, and benefits) for the residual public sector retirement system (which will continue to operate for contributors that are not eligible to cross over to the private system), compensation bonds for young workers moving to the new system, and the modernization of INSS.

24. The pension system reform process advanced rapidly in 2000-01. Progress included: (i) passage of the law to create a supervisory authority; (ii) creation of the institutional structure and staffing of the pension superintendency; (iii) enactment of initial parametric changes to the residual public system; ${ }^{12}$ and (iv) initiating the process of authorizing private pension fund administrators.

${ }^{11}$ See paragraph 27, which describes in more detail the next steps in the process of pension reform.

${ }^{12}$ Law No. 340 (Ley de Sistema de Ahorro para Pensiones) passed in March 1999 establishes the institutional structure for the DC system. It is complemented with a first set of implementing regulations, enacted by presidential decree, which establishes the investment 
25. Progress slowed after these initial steps, raising the transition costs. There was a delay in the appointment of a new superintendent of pensions. This delay, together with unresolved technical and costing details related to the collection and administration of funds and the emergence of other operational issues, caused the target date for receiving applications and granting operating licenses to applicants to be pushed back. As a consequence, current contributors and new affiliates to the pension system have remained longer in the PAYG system administered by INSS than was envisioned initially, raising the transitional fiscal costs of the reform.

26. The reform process regained its momentum in 2003. A new superintendent of pensions assumed office in June 2003, and the INSS was restructured. With these last two steps, the government completed the remaining specific actions called for under the sixth floating completion point condition. The introduction of the new pension system would formally take place, according to Law 340 , when at least two private pension administrators have been authorized to operate and the eligible contributors have been transferred to the new system. The authorities had been planning to take this step by December 2003, but were advised by IDA to delay this process to allow more time for analyzing thoroughly the fiscal implications of the pension reforms. Completing this next step in the reform process is now expected to take place by mid-2004.

27. With a view to ensuring the introduction of a satisfactory pension system and safeguarding fiscal sustainability, the government has updated the estimates of the fiscal impact of the pension reform and of the transition costs involved, ${ }^{13}$ and it has

regime for the private system, the recognition of claims of contributors to the old system, as well as a number of general regulatory aspects. Law No. 388 (Ley Orgánica de Superintendencia de Pensiones) passed in February 2001 establishes the pension superintendency as an independent regulatory and supervisory agency for the system. Approval of this legislation was followed by the enactment of implementing legislation, as well as the establishment of the institutional structure of the superintendency, including drafting of regulations and norms referring to the system's regulation, supervision and operation. This process is still ongoing. In parallel, the contribution rate to the PAYG system was increased in June 2000 through presidential decree and brought up to levels comparable to those established for the DC system, and the relevant wage base for computing benefits under the PAYG system was adjusted. This reduced the immediate fiscal pressure on the PAYG system, but did not alter long-term negative trends.

${ }^{13}$ According to the revised estimates, the annual fiscal deficit associated with the PAYG system averages 1.7 percent of GDP in the medium term (2004-07), rising to a peak of 4.5 percent of GDP in 2023 before declining again. The PRGF-supported arrangement contemplates fiscal adjustments of at least 1.5 percent of GDP to accommodate this deficit in the medium term. Further fiscal adjustments will be needed to accommodate the rising deficit projected in the outer years, unless further parametric changes are introduced in the pension system to contain the fiscal costs of the pension reform. 
approved a detailed roadmap for the next steps in the reform process, with specific time-bound actions. The roadmap includes: (i) parametric reforms to be implemented in light of the revised fiscal impact estimates; and (ii) a vision of the future pension market in terms of the number of agents, pension administrator business models and investment vehicles. ${ }^{14}$ In addition, a satisfactory information sharing system has been designed between the superintendency of banks and the superintendency of pensions, with proper administrative separation between future pension administration funds and related commercial banks. The implementation of the roadmap and information sharing system will be monitored by IDA through the policy conditionality of the proposed PRSC.

\section{G. Divestiture of Public Utilities}

28. The government has advanced substantially in the implementation of its divestiture program, but has not fully complied with the final floating completion point condition, which calls for the divestiture of the telecommunications utility, ENITEL, and all the electricity generating units of the power utility, ENEL. The government succeeded in divesting two electricity generating units, but two others continue to remain in public hands. One of these units, GECSA, is so obsolete that it will be difficult to privatize, although the government will periodically monitor investor interest and meanwhile keep the plant operational for emergency purposes. The other unit, HIDROGESA, could not be divested because of political opposition to privatization. Even if possible, however, its divestiture would not have been advisable at this time, because it would create an undesirable concentration of market power and generate financial problems in the power sector. In any case, the rapid growth of private sector provision of electricity since the late 1990s indicates that the divestiture of these residual generating units has not proven to be indispensable for achieving the sector's development objectives. For these reasons, and considering the overall progress made in the power sector (described below), the staffs of IDA and the IMF recommend a waiver for this condition.

29. To improve its infrastructure, Nicaragua has been seeking to restructure and privatize its energy and telecommunications utilities, while reforming their regulatory framework. The program to privatize the public utilities began with the separation of their operational and regulatory activities and measures to improve their operating and financial performance, followed by the passage of more modern legislation. Regulatory institutions for telecommunications (TELCOR) and for energy (INE) were created in 1995, and a policy of periodic tariff adjustments to bring rates closer to long-term marginal costs was introduced in December 1998 for the telecommunications sector and in September 1999 for the power sector. Following the separation of its regulatory functions, the energy utility (ENEL) was mainly divided into two distribution companies (DISNORTE and DISSUR), one

${ }^{14}$ The roadmap has been agreed upon by the pension superintendency, INSS, the ministry of finance, and the central bank. It has also been ratified by the economic cabinet. 
transmission company (ENTRESA), four electricity generation companies (GEMOSA, GEOSA, GECSA, and HIDROGESA) and the state-owned petroleum distribution company (PETRONIC). ${ }^{15}$ In 1997-98, the national assembly approved several laws to permit private sector participation in the generation and distribution of electricity. A private operator was awarded a long-term concession to manage the petroleum distribution company in 1996, and the two electricity distribution companies were privatized in October 2000, shortly before Nicaragua reached the decision point.

30. The complete divestiture of the public telecommunications company, ENITEL, is still pending, but is expected to conclude in January 2004. Significant progress has been made since the decision point to attract private investment in the telecommunications sector. As a result, access to, and the quality of, telecommunications services in Nicaragua have improved considerably. The Nicaraguan authorities sold 40 percent of ENITEL, plus a concession contract, to a Honduran/Swedish consortium, MEGATEL, in December 2001. The government divested another 11 percent of the shares in 2002 to ENITEL employees according to an agreed distribution procedure. ${ }^{16}$ Since this sale took place, ENITEL has invested US $\$ 90$ million to expand the fixed-line telephone system by 45,000 new lines and to build a new 200,000-mobile-phone system. Also, a third cellular frequency was sold in 2001, so that there are now three operators providing cellular service. ${ }^{17}$ The remaining 49 percent of ENITEL shares in government hands were offered for sale in 2003 and the divestiture process is expected to be concluded in January 2004, prior to the IDA and IMF Board discussions. ${ }^{18}$ Looking forward, the government is planning to fully open up the telecommunications sector to private participants by end-2004, and to promote the extension of telecommunications services in rural areas not covered by current service providers through a recently created Investment Fund for Telecommunications (FITEL).

\section{Significant progress also has been made in attracting private investment to} expand electricity services. After facing increasing bottlenecks in the availability of electricity during the mid-1990s, the country's production capacity increased from $400 \mathrm{MW}$

${ }^{15}$ In addition, there are also several smaller entities that include the Bluefields power distribution company and rural isolated plants that are managed by ENEL.

${ }^{16}$ One percent of the shares was donated, and the other 10 percent was sold to employees.

17. While the percentage of inhabitants with a fixed telephone increased from 3 percent in 2000 to almost 4 percent in 2003, the percentage with cellular access jumped from under 2 percent to an estimated 6 percent.

${ }^{18}$ A public auction for these remaining shares was held on December 12, 2003, but did not yield a winner, as the highest bid did not meet the government's base price. The auction was repeated on December 17, 2003; this time yielding a winning bid. MEGATEL has one month to match the winning bid, so that this sale should be concluded by January 19, 2004 . 
in 1997 to over $600 \mathrm{MW}$ in 2002 , while maximum demand levels have risen to just over $400 \mathrm{MW}$. The prospect of power bottlenecks in the 1990 s provided the main stimulus for seeking to divest the public power generating units, as the most pragmatic way of rapidly attracting private investment into the sector. In line with this strategy, the government succeeded in selling one of the thermal generating companies (GEOSA) in 2001, while giving the geothermal generation company, GEMOSA, in concession to a private operator. Most of the increase in electricity production, however, was due to the entry of several new plants (including cogeneration plants) in the late 1990s, managed by private operators who invested in the sector more vigorously than initially anticipated and now account for over one-half of total electricity generation. Three attempts to sell the other thermal generation company, GECSA, have failed because the plants operated by this company are obsolete, rendering them unattractive to private investors. The attempt to divest the hydroelectric generation company, HIDROGESA, also failed, after it nearly succeeded in 2002. Two offers were received and the company was granted to one of the bidders. However, appeals by the losing bidder and subsequent opposition in the national assembly led to the reversal of the sale and effective prohibition to privatize the company. In hindsight, this proved fortuitous: the privatization of HIDROGESA at this time likely would have been financially disadvantageous to the government ${ }^{19}$ and would have reduced competition within the sector. $^{20}$

${ }^{19}$ Following the recommendations of the investment bank advising the government on privatization in the energy sector, the government established a high value-added margin for the electricity distribution companies to render the distribution companies attractive to foreign investors in spite of the small size of the market and high electricity losses afflicting the system (currently estimated to be around 33 percent). To offer a sufficiently high margin, transition contracts were drawn up between the distribution and generation companies that guarantee a stable energy price to the distributor. These transition contracts expire in 2005. Under this scheme, HIDROGESA, whose marginal costs are extremely low, plays an important stabilizing role, with the result that its government-controlled prices have been held significantly below market prices in recent years. Under these circumstances, the privatization of HIDROGESA, and subsequent lifting of price controls on its output, would have created a serious financial deficit for the government when forced to honor the transition contracts.

${ }^{20}$ The award of HIDROGESA to the winning bidder would have placed one firm in control of 43 percent of the total installed capacity in Nicaragua. The potential dangers of ownership concentration in the power sector were not fully appreciated at the decision point. The importance of having an adequate legal and regulatory framework became fully evident once the electricity distribution companies were privatized to one operator, which put decision making burdens on the government and the regulatory agency that severely taxed their institutional capacity. 
32. The rationale for recommending a waiver on compliance with this completion point condition is based on the finding that the divestiture of the remaining power generating units is neither advisable at this time, nor necessary for achieving sector development objectives. Instead, the authorities are advised to focus their attention on other problems that need to be addressed in the sector. First, distribution losses need to be significantly reduced in order to reduce energy costs to paying customers and relieve HIDROGESA of its cross-subsidizing role before it can be privatized. Second, the sector framework law needs to be revised. It favors spot market arrangements over power purchasing agreements, which discourages private investment in domestic renewable energy generation. Third, a new water law needs to be approved, to clarify water rights and remove the current legal vacuum affecting small, private hydroelectricity projects above $5 \mathrm{MW}$. Fourth, sector regulations need to be revised in order to achieve greater clarity on the rules of the game in the sector and a clearly defined appointment process for regulators that prevents a potential politicization of the regulatory agency. To address these remaining problems, the government will begin implementing a plan agreed with IDA and the IDB to strengthen the sector's policy, legal, and regulatory framework.

\section{Debt Sustainability OVER The Medium Term}

\section{A. Data Reconciliation and Revision of Assistance}

33. At the decision point, the assistance to Nicaragua under the enhanced HIPC Initiative was calculated at US\$3.3 billion in NPV terms. This amount was based on the DSA, on the disbursed and outstanding debt as of end- $1999,{ }^{21}$ presented in the decision point document for Nicaragua. To ensure the accuracy of the decision point calculations, IDA and IMF staffs, together with Nicaraguan authorities, have reviewed the reconciliation of the stock of external debt at end-1999. Approximately 91 percent of total debt has been reconciled, including all the debt owed to multilateral and Paris Club creditors. The results of this exercise confirmed the decision point data for multilateral creditors, while warranting a revision of the debt owed to some bilateral and commercial creditors. The revisions arise from new information on the amount or type of external debt, as well as revisions to calculations. The main changes are described below:

34. Bilateral creditors: (i) moratorium interest of US\$20 million owed to Costa Rica was omitted in the decision point DSA, and has now been included; (ii) debt originally classified as owed to Switzerland was reclassified as multilateral debt, since the Swiss funds used for this loan were transferred to the IDB; (iii) the decision point DSA interpreted incorrectly Paris Club minutes on former short-term debts; however, the correction decreases only slightly the NPV of debt owed to Paris Club creditors; (iv) the decision point DSA did not include certificates of deposit issued by Nicaragua to several central banks in the region

${ }^{21}$ Refers to public and publicly guaranteed external debt. 
(these certificates totaled US\$13.6 million at end-1999); and (v) other small changes were made to debts owed to USAID, Finland, Bulgaria, Hungary, and Russia.

35. Commercial creditors: At the decision point, the debt outstanding with creditors that was not extinguished through the 1995 World Bank-supported commercial debt buyback was excluded from the calculations of enhanced HIPC assistance. Staffs assumed that these debts would eventually be bought back and extinguished. The second buyback operation did not take place as envisioned at the decision point, these debts have now been included in the calculation of assistance to Nicaragua under the enhanced HIPC Initiative after applying the terms of the 1995 buyback operation. ${ }^{22}$

36. The revised DSA also incorporates new data for Nicaraguan exports. For the period 1997-99, the chief revision to the statistics is a US\$51 million reduction in 1997 exports. Under a program intended to promote nontraditional exports, certain Nicaraguan corporations falsified exports of manufactured products to gain tax benefits, leading to the criminal prosecution of the people involved in the scheme. In 2000, the Nicaraguan authorities recalculated export figures during the mid-1990s and arrived at the totals presented now. These modifications were discussed with IMF staff in 2000, and were presented in the 2001 Article IV consultation (Country Report No. 01/171, October 2, 2001), which also noted the weakness of external trade statistics. Minor increases in 1998 and 1999 exports (both of less than US\$4 million) due to underinvoicing are also included in the revised DSA.

\section{After full application of traditional debt relief mechanisms, ${ }^{23}$ the revised NPV of} external debt as of end-1999 amounts to US\$4.54 billion, compared with US\$4.52 billion as estimated at the decision point. The staffs recommend that debt relief to Nicaragua under the enhanced HIPC Initiative be amended to take into account these data revisions. ${ }^{24}$ Additional assistance to Nicaragua requested to bring down the NPV of external debt-toexports ratio as of end-1999 to 150 percent amounts to US\$41 million, equivalent to 5 percent of the revised exports. The common reduction factor that creditors would need to apply to the updated stock of debt as of end -1999 would be 72.8 percent, compared with 72.2 percent as in the decision point document. Financing assurances will be sought from

${ }^{22}$ After application of traditional debt relief, the NPV of debt from these creditors would amount to US\$16 million.

${ }^{23}$ Refers to a stock-of-debt operation on Naples Terms for Paris Club creditors, and at least comparable treatment from non-Paris Club creditors, including the application of the 1995 buyback terms for commercial creditors.

${ }^{24}$ The differential in assistance represents about 3 percent of the targeted NPV of US $\$ 1,233$ million and thus meets the 1 percent threshold required for revisions of decision point assistance. 
Nicaragua's creditors for their additional assistance according to the new common reduction factor.

\section{B. Updated Debt Sustainability Analysis}

\section{ExternaJ Debt Situation at End-2002}

38. The DSA included in the Decision Point Document has been updated jointly by the Nicaraguan authorities and the staffs of IDA and the IMF. The stock of debt disbursed and outstanding was updated on the basis of end-2002 loan-by-loan information provided by the authorities. This information has been reconciled with creditor statements from all multilateral and Paris Club creditors, as well as most non-Paris Club creditors. The exchange rates and discount rates used for the calculating Nicaragua's nominal and NPV debt as of end-2002 are presented in Table 6.

39. Based on the reconciled debt data, Nicaragua's nominal stock of disbursed and outstanding external debt reached US\$6.7 billion at end-2002, compared with US $\$ 7.0$ billion at end-1999. ${ }^{25}$ Of the total nominal debt as of end-2002, 38.3 percent was owed to multilateral creditors, 47.5 percent to bilateral creditors and 14.3 percent to commercial creditors. Nicaragua's largest official creditors at end-2002 were the IDB and IDA, accounting for 16.4 percent and 12.2 percent of total debt, respectively.

40. The NPV of Nicaragua's debt at end-2002, after full application of traditional debt relief mechanisms, is estimated at US $\$ 4.7$ billion, equivalent to 507 percent of the exports of goods and nonfactor services. Of this amount, about 8 percent (US $\$ 357$ million or 38 percent of exports) corresponds to disbursements made over the period 2000-02 on loans existing as of end-1999 and new loans contracted since then. Other reasons underlying the increase since decision point, including arrears accumulation and adverse discount rate and export price shifts, are outlined in Section $\mathrm{C}$ below. After assuming full delivery of the revised HIPC debt relief (as proposed in section A. of this chapter), the NPV of external debt would be reduced to US $\$ 1.5$ billion, equivalent to 161 percent of the exports at end- 2002 . Finally, after taking into account additional bilateral debt relief, the NPV of external debt would be reduced to US $\$ 1.3$ billion, equivalent to 139 percent of exports. The NPV of external debt would then gradually rise to US $\$ 3.3$ billion by end- 2022 .

\section{External Debt Outlook, 2003-22}

41. The authorities' medium- and long-term macroeconomic framework envisages sound macroeconomic policies and stable economic growth. ${ }^{26}$ Annual real GDP growth is

${ }^{25}$ The debt data are based on parameters prevailing at the end of each year.

${ }^{26}$ The assumptions underlying the macroeconomic framework are explained in more detail in Appendix II. 
projected to rise to about 5 percent. Inflation, which has been on a downward trend in recent years, is expected to be around $2 \frac{1 / 2}{2}$ percent a year in the long term. Nicaragua's still-fragile total public debt position will require continued fiscal consolidation. The fiscal deficit is targeted to narrow substantially. The external current account balance is expected to improve in the medium term, helped by a continued trend away from commodity exports and into services, particularly tourism, and manufactured exports. The authorities are currently assessing long-term exchange rate policy, but in the near term they expect to maintain the current crawling peg regime.

42. Nicaragua's external debt will be reduced significantly once the country benefits from full provision of HIPC assistance at the completion point. The NPV of Nicaragua's debt is projected to fall from US $\$ 4.7$ billion at end-2002, after full use of traditional debt relief mechanisms, to US $\$ 1.8$ billion at end-2004, after full delivery of the assistance under the enhanced HIPC Initiative (including US $\$ 347$ million in NPV terms of projected new borrowing for 2003-04). Additionally, the provision of voluntary bilateral debt relief beyond the enhanced HIPC Initiative would reduce the NPV of Nicaragua's external debt at end2004 by a further US $\$ 181$ million, to US $\$ 1.6$ billion. Then, as new external debt is built up and the concessionality of old debt is reduced, ${ }^{27}$ the NPV of external debt is projected to gradually increase to reach US\$3.3 billion in 2022, or about 97 percent of exports, still much lower than at end-1999.

43. Notwithstanding this reduction, the trajectory of the NPV of external debt-toexports ratio is expected to exhibit a hump. The recent increase in disbursements, while highly concessional, will increase the NPV of Nicaragua's debt in the near term, though the impact on debt service will be small. Based on the long-term macrocconomic framework described above and in Appendix II, the provision of HIPC assistance would result in an NPV of external debt-to-exports ratio at end-2002 of 161 percent, compared with a level of 128 percent projected at the decision point. Bilateral debt relief beyond HIPC would further reduce the ratio to 139 percent at end-2002. Starting in 2003, the ratio is projected to increase gradually and reach a peak of 176 percent in 2005 . However, starting in 2006, the ratio would decline steadily.

44. The trajectory of the NPV of external debt-to-exports ratio is accompanied by a lower projected external debt service-to-exports ratio. In 2003, Nicaragua's projected debt service due after traditional debt relief mechanisms would have represented 33 percent of exports ${ }^{28}$ (US $\$ 313$ million). After the provision of debt relief in the context of the enhanced HIPC Initiative and bilateral assistance beyond HIPC, debt service payments were

\footnotetext{
${ }^{27}$ Nicaragua's stock of debt as at end-2002 (old debt) has been contracted mostly on concessional terms. As concessional debt matures, it becomes less and less concessional.

${ }^{28}$ In the case of the external debt service-to-exports ratio, exports refers to the exports of goods and nonfactor services for the current year.
} 
only 11 percent of exports (US\$102 million), and would remain below that level thereafter. Over the period 2004-22 this ratio would average 7 percent, but fluctuate between 6 and 9 percent due to the profile of debt relief delivery of some creditors. The ratio stabilizes at less than 7 percent during 2015-19, before increasing slightly again due to declining access to highly concessional financing. The external debt service-to-revenue ratio follows a similar pattern. In the medium term, debt service is expected to remain well below decision point forecasts, largely due to voluntary additional relief offered by official bilateral creditors.

\section{Consideration of Additional Relief}

45. The table below presents a decomposition of the factors underlying the increase in the NPV of external debt-to-exports ratio at end-2002 ${ }^{29}$ relative to the ratio projected at the decision point ( 161 percent against 128 percent). The net increase is the product of several factors (some positive, some negative), including (i) changes in the discount rates and exchange rates used for the calculation of the NPV of external debt; (ii) less than anticipated external borrowing undertaken since the decision point; (iii) lower exports over the period 2000-02 than projected at the time of the decision point; (iv) accumulation of arrears with bilateral creditors; and (v) inclusion of debts to commercial creditors plus arrears during the interim period. The relative importance of each factor is shown in the table below. Including additional bilateral relief beyond the terms of the enhanced HIPC Initiative, the ratio of the NPV of external debt to exports is 139 percent.

${ }^{29}$ This ratio assumes full delivery of enhanced HIPC assistance, but does not incorporate the impact of additional bilateral debt relief beyond HIPC. This assumption enables a comparison with the decision point projection which was calculated in the same manner. 
Nicaragua. Breakdown of the Increase of NPV of Debt-to-Export Ratio at end-2002 $1 /$

\begin{tabular}{|c|c|c|}
\hline & Percentage Points & $\begin{array}{r}\text { Share of total increase } \\
\text { (in percent) }\end{array}$ \\
\hline NPV of debt-to-exports ratio (as projected at Decision l'oint) & 128.0 & n.a. \\
\hline NPV of debt-to-exports ratio (actual) & 161.3 & n.a. \\
\hline Total increase & 33.2 & 100.0 \\
\hline 1. Due to changes in the parameters & 13.1 & 39.4 \\
\hline o/w due to changes in the discount rates & 14.6 & 43.9 \\
\hline $\mathrm{o} / \mathrm{w}$ due to changes in the exchange rates & $(1.5)$ & -4.5 \\
\hline 2. Due to unanticipated new borrowing & (11.6) & $-35,0$ \\
\hline o/w due to higher than expected disbursements & (12.6) & -38.0 \\
\hline $\mathrm{o} / \mathrm{w}$ due to lower concessionality of the loans & 1.0 & 2.9 \\
\hline 3. Due to changes in exports & 15.7 & 47.2 \\
\hline o/w due to changes in exports of goods & 10.9 & 32.8 \\
\hline o/w due to changes in volumes. & 0.2 & 0.6 \\
\hline $\mathrm{o} / \mathrm{w}$ due to changes in prices & 10.6 & 31.9 \\
\hline o/w due to changes in exports of services & 4.8 & 14.4 \\
\hline 4. Arrears accumulated between during the interim period & 5.0 & 15.0 \\
\hline 5. Other factors $2 /$ & 11.2 & 33.7 \\
\hline \multicolumn{3}{|l|}{ Memorandum Item: } \\
\hline NPV of debt to exports ratio after additional bilateral debt relief (actual) & 138.6 & n.a. \\
\hline
\end{tabular}

Source: IDA and IMF staff estimates.

1/ NPV of debt-to-exports ratio assuming full delivery of HIPC assistance. unless otherwise indicated.

2/ Includes revisions in the end-1999 database and changes in the delivery of interim assistance compared to the decision point projections.

\section{Between decision point and completion point, Nicaragua's export performance} was worse than expected. In 2002, exports of goods and nonfactor services were 4 percent lower than 2000 exports, largely due to a decline in the exports of goods. A decomposition of export performance reveals that the volume of exports rose by 9.3 percent during $2000-02$, while export prices generally fell. The prices for coffee (down by 36 percent), seafood ( 30 percent), and sugar ( 9 percent) were particularly hard hit during this period, and minor increases in the prices of bananas and beef did little to compensate for these declines. Depressed export prices account for less than one-third of the increase in the ratio of NPV of external debt-to-exports.

47. Consistent with the enhanced HIPC Initiative methodology, the DSA at the completion point used the discount rates and the exchange rates of end-2002. The changes observed in these parameters between end-1999 and end-2002 resulted in a net increase of 13.1 percentage points in the NPV of external debt-to-exports ratio (explaining 39 percent of the total increase in the ratio). Practically all this contribution results from the 
decrease of the discount rates observed between end-1999 and end-2002. ${ }^{30}$ The end-2002 exchange rates used to calculate the NPV of external debt remained very close to their end1999 levels and contributed to a very small decline in the NPV of external debt-to-exports ratio (around 1.5 percentage points).

\section{The remaining changes in the NPV of external debt-to-exports ratio are} explained by a number of factors. New external borrowing was substantially lower than anticipated in the decision point document, reducing the debt ratio by 12 percentage points. However, approximately 5 percentage points of the deterioration in the NPV of external debtto-exports ratio since the decision point can be attributed to arrears accumulated by Nicaragua to official creditors during the interim period, including arrears to the Paris Club for which interim relief would have been available had Nicaragua's program been on track during 2001-02. In addition, the inclusion of commercial debt excluded at decision point raised the end-2002 ratio by 2 percentage points.

49. Nicaragua does not meet the conditions for topping up. Relative to projections at the decision point, the NPV of external debt-to-exports ratio deteriorated to 161 percent, largely on account of exogenous factors. However, after including bilateral debt relief beyond the terms of the enhanced HIPC Initiative, the ratio is reduced to 139 percent below the 150 percent HIPC threshold.

\section{Sensitivity Analysis and Long-Term Debt Sustainability}

50. This section assesses debt sustainability under two alternative scenarios. The first considers stagnant export carnings, the second a temporary increase in domestic absorption financed by external borrowing.

\section{Alternative Scenario 1: Stagnant Exports}

\section{This scenario examines the implications of continued export stagnation for the} debt profile. While Nicaragua's export base is somewhat diversified, particularly compared with many other low-income countries, it remains vulnerable to external shocks and changes in commodity prices, such as for coffee, sugar, beef, and shrimp. During the interim period, low export prices kept Nicaragua's exports relatively stagnant. The baseline scenario projects a rebound in export growth in the medium term, with growth rates in excess of 6 percent, rising to 7-71/2 percent over the long term. This alternative scenario assumes that the recent stagnation in exports continues until 2007 , at which point the growth rates of the baseline scenario apply again, but to a lower base. Some of the shortfall in the current account

${ }^{30}$ SDR and U.S. dollar discount rates declined from 5.6 percent to 4.8 percent and from 7.0 percent to 5.1 percent, respectively. However, the Euro discount rate increased slightly from 5.5 percent to 5.6 percent (Table 10). 
(25 percent) is covered by reduced imports, but the remainder is financed by external borrowing, on terms analogous to those in the baseline scenario. Fiscal revenues are assumed unchanged.

\section{The extended period of export stagnation yields a considerably higher debt} burden, with a modest increase in the debt-service ratio. In the alternative scenario, exports fall short of the baseline scenario by about 10 percent, with additional disbursements of US\$41 million in 2005 rising to US\$133 million in 2008, growing at the same rate as exports thereafter. This causes a sizeable increase in the external debt burden. By 2008, the ratio of NPV of external debt to exports would reach 203 percent ( 30 percentage points over the baseline), eventually rising to as much as 36 percentage points over the baseline before beginning to fall. ${ }^{31}$. The change in the debt service burden is more modest. Under the baseline, the debt-service-to-exports ratio remains below 10 percent. However, under the alternative scenario it rises above 10 percent in 2007-08 and remains higher than the baseline thereafter. The increase in the debt and debt-service burdens, and the consequent delay in attaining the HIPC thresholds, shows the importance of sustained export growth for Nicaragua. Even a relatively short period of stagnation could cause a large increase in the debt burden.

\section{Alternative Scenario 2: Increased Domestic Absorption}

53. A second alternative scenario simulates the impact of a large increase in domestic absorption. Such an increase has occurred in the past during periods of political instability or after natural disasters. In this scenario, current public expenditures rise by 20 percent during 2005-07, financed by foreign disbursements on terms identical to those of the baseline scenario.

54. As in the previous scenario, the increase in domestic absorption raises the profile of the debt stock and delays reaching the HIPC threshold of 150 percent. The debt stock peaks in 2007, two years later than under the baseline, at 197 percent of exports of goods and nonfactor services. Reduction of the NPV of the debt stock below 150 percent of exports is achieved four years later than under the baseline. The high degree of concessionality and long grace periods of most disbursements imply that the profile of Nicaragua's external debt service does not change dramatically during the period of high domestic absorption; the ratio of debt service to exports does not rise more than one percentage point above the baseline until 2015. However, as grace periods draw to a close, debt service increases. Under the

${ }^{31}$ Under the baseline scenario, this ratio (defined as the ratio of NPV of total external debt after additional relief beyond HIPC assistance to a three-year moving average of exports of goods and nonfactor services) falls below 150 percent in 2014, while under the alternative scenario this is only achieved in 2019. The ratio reaches its maximum value of 176 percent in 2005 under the baseline, whereas it reaches a maximum of 204 percent in 2008 under this alternative scenario. 
baseline, debt service during the last five years of the exercise averages 8 percent of exports of goods and nonfactor services. However, amortization payments coming due at the end of the simulation period increase this average by about 1 percentage point under the second alternative scenario (an increase of about 12 percent points compared with the baseline).

55. This scenario highlights that Nicaragua's fiscal position will remain precarious in the medium term without sustained implementation of a prudent fiscal policy. A period of large-scale borrowing to finance nonproductive expenditures, even on highly concessional terms, could easily push the country beyond the thresholds established under the HIPC Initiative. Clearly, this negative outcome would be exacerbated if the increase in domestic absorption were financed with domestic borrowing. The drawn-out profile of amortization payments under the assumption of concessional borrowing, has the effect of maintaining that debt service elevated for a long period. Therefore, if it becomes necessary to increase government expenditures, the authorities should seek grant financing to the extent possible.

\section{Long-Term Debt Sustainability}

56. These alternative scenarios underscore the importance for Nicaragua of following prudent fiscal and debt-management policies. The external debt remains large after completion point, partly because some of Nicaragua's official creditors have either refused to provide or have not yet determined the modalities of relief. Moreover, the remaining holders of commercial bank debt have not yet agreed to participate in the enhanced HIPC Initiative or in a second buyback operation. Nonparticipation of creditors heightens the risk to long-term debt sustainability. A combination of improved revenue measures and expenditure streamlining, as envisioned under the authorities' program supported by the IMF and IDA, should help ensure that fiscal deficits are further reduced over the medium term. The scenarios presented above show that the debt burden could rapidly rise again in the face of repeated external shocks or high public expenditure growth, and that securing highly concessional terms, preferably grants, to cover financing needs will remain critical.

\section{Status of Creditor Participation}

57. Nicaragua has received assurances of participation in the enhanced HIPC Initiative from multilateral and bilateral creditors accounting for 87 percent of the NPV of HIPC assistance at the decision point (as recalculated using revised debt stocks). Interim assistance has been provided by multilateral creditors, the Paris Club, and certain non-Paris Club official creditors. The authorities are working toward signing agreements with all remaining creditors. 


\section{A. Multilateral Creditors}

58. Debt relief from multilateral creditors under the enhanced HIPC Initiative, as estimated at the decision point, amounts to US\$1.1 billion in NPV terms (or 34 percent of total relief to Nicaragua). ${ }^{32}$ IDA, IBRD, IMF, CABEI, IDB, and the OPEC Fund, have granted interim assistance. The International Fund for Agricultural Development (IFAD) and the Nordic Development Fund (NDF) have committed to provide the assistance required under the enhanced HIPC Initiative as soon as Nicaragua reaches the completion point. However, full participation from multilateral creditors is not secured since the Fondo Centroamericano de Estabilización Monetaria (FOCEM), representing 0.1 percent of total enhanced HIPC assistance, has not so far committed to provide its share of assistance.

59. Assistance from IDA. Debt relief from IDA under the enhanced HIPC Initiative amounts to US\$189 million in NPV terms. This assistance is being delivered through a reduction of 90 percent of the debt service falling due to IDA, on disbursed and outstanding credits to IDA as of end-December 1999. This mechanism will be applied during January 2001-October 2023, providing a cumulative nominal assistance of US\$379 million. Of this amount, US\$21 million has already been delivered as interim assistance during January 2001-October 2003. Debt service savings from IDA are expected to amount US\$8 million for 2003 and would average US $\$ 14$ million a year over the next 10 years.

60. Assistance from the IMF. Enhanced HIPC assistance from the IMF amounts to SDR 63 million in NPV terms (approximately US\$81 million). ${ }^{33}$ IMF assistance will be delivered through grants from the PRGF/HIPC Trust Fund to an escrow account. These resources, plus accrued interest, would cover approximately 72 percent of the payments falling due to the IMF during 2002-09 on Nicaragua's obligations as of August 2000. Total nominal debt service savings are expected to amount to SDR 82 million, of which about SDR 3 million was provided as interim assistance through October 2003.

61. Assistance from CABEI. Enhanced HIPC assistance from CABEI amounts to US $\$ 435$ million in NPV terms. Total assistance provided to Nicaragua during the interim period amounted to US\$234 million in NPV terms. Of this amount, US\$146 million was provided with CABEI's internal resources, US $\$ 28$ million through contributions to the CABEI-HIPC Special Fund and US $\$ 60$ million with resources from the HIPC Trust Fund. At the completion point, CABEI will deliver the rest of the assistance through a partial cancellation of Nicaragua's debt and the rescheduling of the remaining amount over 20 years.

62. Assistance from the IDB. Debt relief from the IDB under the enhanced HIPC Initiative amounts to US\$387 million in NPV terms (US\$728 million in nominal terms). This

\footnotetext{
${ }^{32}$ Using revised end-1999 data, debt relief from multilateral creditors would rise by US\$11 million.

${ }^{33}$ Based on the US\$/SDR exchange rate as of end-December 1999.
} 
assistance is being provided through the reduction of debt service payments to the IDB during 2001-19, on disbursed and outstanding debt as of end-December 1999. As of October 2003, about US\$88 million had been provided as interim assistance.

63. Assistance from the OPEC Fund. OPEC Fund assistance under the enhanced HIPC Initiative amounts to US\$15 million in NPV terms. Of this amount, US\$4 million were provided in 2002 through a concessional loan for US\$10 million. Part of these resources were used in 2002 to repay Nicaragua's arrears toward the OPEC Fund, and the remaining amount is being used to meet the repayment of principal and interest amounts on the debt owed to the OPEC. It is expected that the balance of the assistance will be provided once Nicaragua reaches the completion point.

64. Assistance from IFAD and NDF. IFAD and NDF will deliver their share of assistance under the enhanced HIPC Initiative (US\$7 million and US\$3 million, respectively) through a reduction of 100 percent of debt service payments starting from the completion point. IFAD's assistance is administered through its own HIPC Trust Fund, which will pay the debt service on behalf of Nicaragua as it falls due until the Trust Fund resources for Nicaragua are exhausted. A similar mechanism is used by NDF, but it operates through the HIPC Trust Fund administered by IDA. It is estimated that the assistance under the enhanced HIPC framework could be delivered by IFAD until 2017, and by NDF until 2014.

\section{B. Bilateral and Commercial Creditors}

\section{Paris Club creditors' share of assistance under the enhanced HIPC Initiative} amounts to US\$0.9 billion. Interim relief from the Paris Club was provided through a flow rescheduling under Cologne terms in December 2002. Nicaragua has now signed bilateral agreements with all of these creditors with the exception of Israel. Finland has already cancelled 100 percent of the outstanding obligations and a similar treatment was provided by the Netherlands on ODA debt and the debt consolidated in the December 2002 Agreed Minute. Brazil has provided 90 percent of relief through a stock operation. Following completion point, most Paris Club creditors will provide assistance beyond that required under the enhanced HIPC Initiative.

66. The debt relief contribution of Nicaragua's 24 non-Paris Club official creditors amounts to US\$1.2 billion in NPV terms. Rescheduling agreements were signed with the Czech Republic and Mexico before the decision point, and this relief has been considered sufficient for the purposes of the enhanced HIPC Initiative. During the interim period, agreements were signed with Bulgaria, Guatemala, and Slovakia, who accounted for 27 percent of the outstanding debt to non-Paris Club official creditors at end-1999. The outstanding debt to Guatemala (US\$487 million at decision point) was swapped with Guatemalan debt to Spain and written down by 89 percent. Debts to Bulgaria and Slovakia were written down by 90 percent, in line with Paris Club terms. These three countries provided relief beyond the requirements of the enhanced HIPC Initiative. The status of negotiations with the remaining official non-Paris Club creditors is described below: 
- Discussions have been opened and the authorities are optimistic about progress toward settlement with Costa Rica, Hungary, Peru, and Poland (18 percent of outstanding bilateral debt). ${ }^{34}$

- Honduras (4 percent) has stated its willingness to provide HIPC relief.

- Libya and India ( 7 percent) have both stated their willingness to provide relief to HIPCs under the enhanced HIPC Initiative.

- The Nicaraguan authorities have contacted Algeria, China, Venezuela and the Former Federal Republic of Yugoslavia (5 percent). The authorities of these countries have not responded.

- Nicaragua hopes to open discussion soon on the debts to Iran (4 percent).

- Nicaragua also has debts to North Korea (0.2 percent), which has not accepted Paris Club-comparable terms, and Taiwan Province of China (6 percent), which has refused to participate in the enhanced HIPC Initiative.

67. Nicaragua has a large stock of external commercial debt, including debt owed to commercial creditors who did not participate in the 1995 commercial debt buyback program. Participation of commercial creditors in the enhanced HIPC Initiative is essential for achieving long-term debt sustainability, and the Nicaraguan authorities intend to seek discussions with the holders of these debts. ${ }^{35}$ A second buyback operation supported by the World Bank's Debt Reduction Facility for IDA-only Countries is an option actively under consideration.

\section{ISSUES FOR DISCUSSION}

Executive Directors may wish to focus on the following issues and questions:

- Do Directors agree that Nicaragua has met the conditions for reaching the completion point under the enhanced HIPC Initiative, as established at the time of the decision point, and that the waiver on the condition to divest all the generating units of the power utility, ENEL, is warranted?

\footnotetext{
${ }^{34}$ Percentages refer to end-2002 stock of debt before debt relief in NPV terms.

${ }^{35}$ Some of these creditors have won court judgements against Nicaragua. See the Staff Report 10/3/03 for more detail.
} 
- Do Directors agree with the staffs' recommendation to revise the debt relief to Nicaragua under the enhanced HIPC initiative in light of the findings from the data reconciliation exercise?

- Do Directors agree that sufficient assurances have been given by Nicaragua's other creditors to commit enhanced HIPC Initiative assistance to Nicaragua, as approved at the decision point and amended in the data reconciliation exercise, on an irrevocable basis?

- Do Directors agree that there has been no fundamental change in Nicaragua's circumstances to justify additional enhanced HIPC Initiative assistance above the amount committed at the decision point and amended in light of the data reconciliation exercise?

- Do Directors agree that Nicaragua's PRSP and expenditure-tracking mechanism provide adequate assurance that assistance provided under the enhanced HIPC Initiative and other sources will further poverty-reduction efforts? 
Box 1: Status of Poverty Reduction and Structural Measures for Reaching the Enhanced HIPC Initiative Floating Completion Point

1. Preparation of a fully participatory PRSP and its satisfactory implementation for at least one year as evidenced by the JSA of the country's annual progress report presented to the Boards of the MF and IDA. The full PRSP was submitted to the MF Board in September 2001. A report of the second year of its implementation was presented in November 2003.

2. The use of budgetary savings resulting from the interim relief under the enhanced HIPC lnitiative would be in accordance with the proposals set out in Appendix III (www.imf.org), and would be reported in the PRSP process. A reliable tracking mechanism of poverty reducing expendilures was approved and is operating.

3. Maintenance of a stable macroeconomic framework, and satisfactory performance under a program supported by a PRGF arrangement. The Board approved the first and second reviews under the three-year PRGF arrangement in June 2003, and the third review in October 2003. Fourth review is presented for Board approval.

4. Implementation of reforms to promote human capital development and social protection. Key reforms are: a. Approval of a satisfactory school autonomy law to strengthen the legal foundations for the envisaged sector reform, which aims at encouraging, inter alia, greater parental participation in education. A law considered satisfactory by the World Bank was approved in February 2002. Implementing regulations in place since 2002. b. Approval of a satisfactory general health law and adoption of corresponding implementing regulations to strengthen the health ministry's regulatory and normative roles, and establish a solid legal framework for the sector's modemization program, granting more autonomy to hospitals and local health systems. A law deemed satisfactory by the World Bank became effective in November 2002. Implementing regulations were approved and published in January 2003. Law is being implemented.

c. Adoption of an action plan to introduce an effective social protection program, based on the results of a pilot program started in 2000. A pilot program was concluded in 2002 and the second phase of the social protection net program is under implementation.

5. Implementation of governance strengthening measures, which encompass:

a. Enactment and advance in implementation of a satisfactory civil service law to, inter alia, reduce political interference in hiring/firing decisions affecting civil servants. Law was approved in November 2003 and significant progress has been made in implementing the law.

b. Introduction of a satisfactory system of management and inspection of public sector procurement. Implementation of the program agreed with the IDB started in October 2002. Satisfactory system in place.

c. Satisfactory progress in implementing the plan to strengthen and improve the efficiency of the comptroller's office. Program agreed with the IDB started in December 2002. Satisfactory implementation.

d. Approval of the law on penal procedures and initiation of training programs and technical preparations for its implementation. A law on penat procedures (Law 4I1) was published in December 2001. Implementation of the law started at end-2002. Training programs and technical preparations are advanced.

e. Approval of the law on public prosecutors and initiation of training programs and technical preparations for its implementation. A law on public prosecutors (Law 342) was published in October 2000. Implementing regulations approved. Training programs and technical preparations are advanced.

6. Implementation of remaining actions needed to introduce a satisfactory pension system of funded private sector managed, and individual accounts. This includes especially the passage of a law to create a supervisory authority for pension funds, the staffing of this supervisory authority, and the restructuring of the social security institute. A new Pension Law had been approved in 1999 and the Pension Superintendency Law was approved in 2001. The pension superintendency has been staffed and a new superintendent was appointed in early June 2003. Measures to restructure INSS have been implemented. The government has updated the estimates of the fiscal impact of the pension reform and of the transition costs involved and approved a detailed roadmap for the next steps in the process, with specific time-bound actions.

7. Divestment of:

a. ENITEL: 40 percent of ENITEL's shares were divested and a management contract was awarded in August 2001 . Workers were given 1 percent of the shares, and offered an additional 10 percent for purchase. The government received a viable offer for the remaining shares of ENITEL in December 2003 and expects to complete the sale in January 2004.

b. All remaining electricity-generating units of ENEL: The authorities succeeded in divesting two electricity generating plants (Geosa, Gemosa), but two others remain in public hands (Hidrogesa, Gecsa). Investors have shown little interest in Gecsa, which is obsolete, and the authorities have determined, in close consultation with the IDB, that privatization of Hidrogesa is not advisable at this time, since it could result in an excessive concentration of market power in one firm. Power generating capacity has been rising as a result of increased private sector participation. To improve overall efficiency in the power sector, the authorities will begin implementing a plan agreed with IDA and the IDB to strengthen the sector's policy, legal, and regulatory framework.

\begin{tabular}{|c|c|}
\hline \multicolumn{2}{|c|}{ Monitoring Institution and } \\
Compliance
\end{tabular}




\section{Box 2: Selected Social and Demographic Indicators}

Nicaragua's social and demographic indicators generally have been improving, but at a very gradual pace. The population living in poverty has fallen steadily in the $1990 \mathrm{~s}$, from 50.3 percent in 1993 to 47.9 percent in 1998 and to 45.8 percent in 2001 , while that in extreme poverty fell from 19.4 percent to 17.3 percent, and to 15.1 percent over the same period (see table below). However, fertility rates continue to be high, progress in education is mixed, access to basic water and sanitation infrastructure has progressed modestly, and diarrhea and upper respiratory infections for children under five show little progress since the early 1990s.

Looking forward, sustained broad-based growth will be critical for advancing poverty reduction as well as meeting the PRSP targets and the MDGs by 2015. Under current trends, the PRSP targets for extreme poverty, under-five mortality and access to water and sanitation are likely to be met. Additional efforts will be required to meet the targets for primary enrollment, maternal and infant mortality, access to reproductive healthcare services, chronic malnutrition, and illiteracy.

Nicaragua: Selected Sxcial and Demographic Indicators, 1999-2002

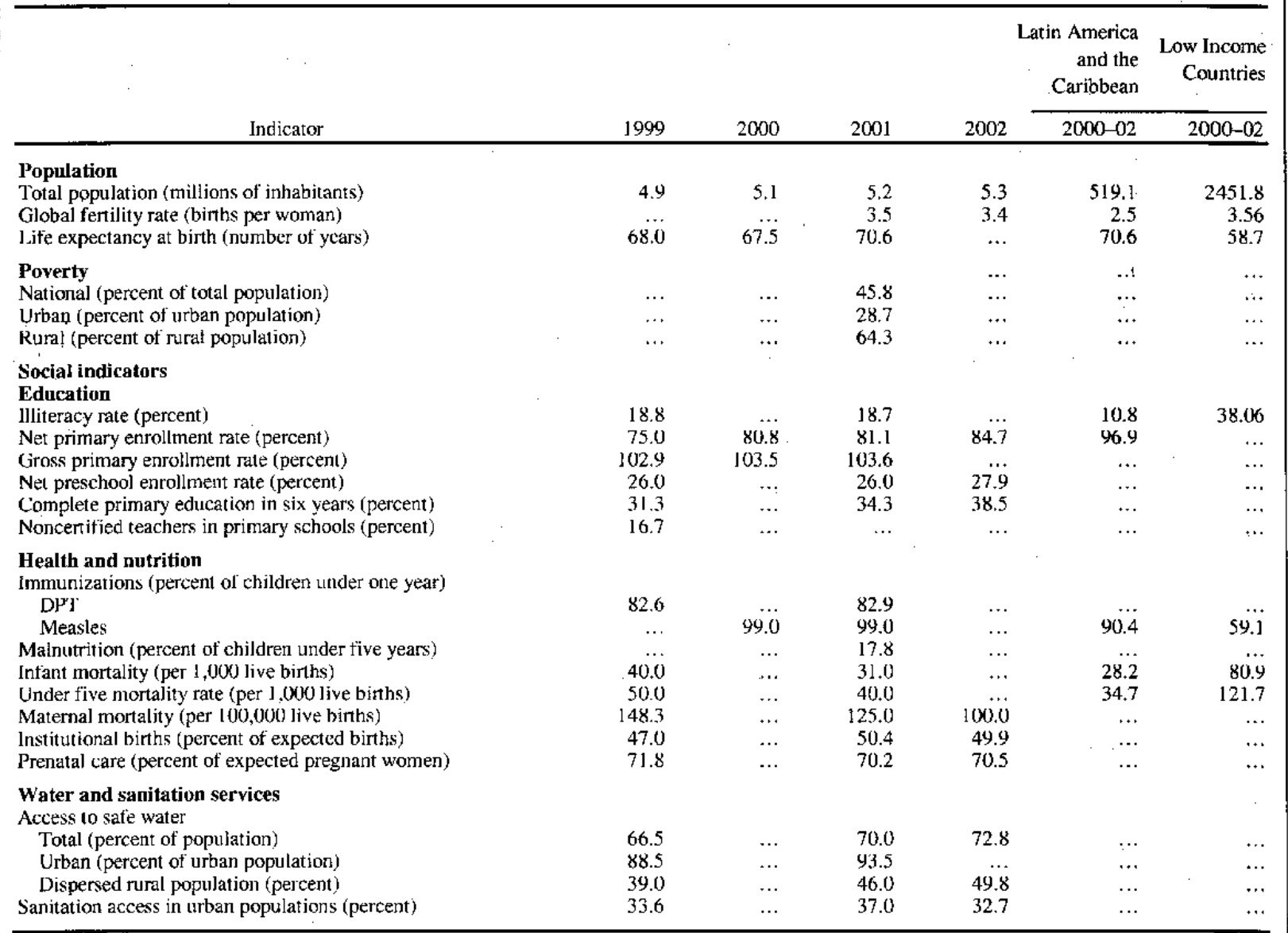

Sources: World Development Indicators (WDR) for Latin America and the Caribbean and for Low- Income Countries; for Nicaragua: Living Standards Measurement Survey (LSMS) 1993, 1998, 2001. Family Health Survey (ESF) 1993, Demographic and Health Survey (DHS) 1998, 2001; and PRSP, PRSP Progress Reports. 


\section{Box 3: Total and Poverty-Reducing Expenditures}

The table below provides an overview of public spending in Nicaragua during 2001-03. Total public spending is divided into spending on interest obligations and primary spending, where the latter is divided, in turn, into poverty-reducing spending (denoted PRSP spending) and non-PRSP spending. Total PRSP spending is divided further into spending on post-hurricane Mitch reconstruction activities, which were phased out in 2002, and other programs, denoted adjusted PRSP spending.

As shown in the last column on the right, total external resources dedicated to adjusted PRSP spending have increased by a cumulative US\$366.6 million during 2001-03, of which US\$235 million represents HIPC interim relief during this period. This increase in external resources helped to finance a cumulative increase in adjusted PRSP spending of US\$164.8 million, while freeing up US\$201 million in domestic resources to help finance an increase of US $\$ 291$ million in interest payments, due on the domestic debt and on foreign obligations (including on previously deferred Paris Club debt). Since domestic resources devoted to non-PRSP. spending declined by a cumulative US $\$ 49.5$ million during this period, we can conclude that the domestic resources freed up by HIPC relief did not contribute toward raising non-PRSP spending (see table below).

Nicaragua: Nonfinancial Public Sector Balance

\begin{tabular}{|c|c|c|c|c|c|}
\hline & \multirow[b]{2}{*}{2000} & \multirow[b]{2}{*}{2001} & \multicolumn{3}{|c|}{ Estimate } \\
\hline & & & 2002 & 2003 & $2001-031 /$ \\
\hline \multicolumn{6}{|c|}{ (ln millions of U.S. dollars) } \\
\hline Total income & 791.1 & 785.0 & 814.8 & 900.1 & 126.6 \\
\hline $\begin{array}{l}\text { Total expenditure } \\
\text { Of which: interest }\end{array}$ & $\begin{array}{r}1127.9 \\
110.1\end{array}$ & $\begin{array}{r}1284.7 \\
212.7\end{array}$ & $\begin{array}{r}1157.9 \\
229.4\end{array}$ & $\begin{array}{r}1175.4 \\
179.2\end{array}$ & $\begin{array}{l}234.3 \\
291.0\end{array}$ \\
\hline Total PRSP spending & 456.9 & 455.3 & 409.1 & 450.0 & -56.3 \\
\hline $\begin{array}{l}\text { Adjusted PRSP spending } \\
\text { Financing }\end{array}$ & 349.4 & 361.9 & 401.1 & 450.0 & 164.8 \\
\hline $\begin{array}{l}\text { Domestic } \\
\text { External }\end{array}$ & $\begin{array}{l}216.8 \\
132.6\end{array}$ & $\begin{array}{l}152.5 \\
209.4\end{array}$ & $\begin{array}{l}152.9 \\
248.2\end{array}$ & $\begin{array}{l}143.2 \\
306.8\end{array}$ & $\begin{array}{r}-201.8 \\
366.6\end{array}$ \\
\hline $\begin{array}{l}\text { Of which: HIPC } \\
\text { Other }\end{array}$ & $\begin{array}{r}0.0 \\
132.6\end{array}$ & $\begin{array}{r}63.3 \\
146.1\end{array}$ & $\begin{array}{r}70.8 \\
177.4\end{array}$ & $\begin{array}{l}100.9 \\
205.9\end{array}$ & $\begin{array}{l}235.0 \\
131.6\end{array}$ \\
\hline $\begin{array}{l}\text { Mitch-related spending } \\
\text { Financing }\end{array}$ & 107.5 & 93.4 & 8.0 & 0.0 & -221.1 \\
\hline $\begin{array}{l}\text { Domestic } \\
\text { External }\end{array}$ & $\begin{array}{l}35.1 \\
72.4\end{array}$ & $\begin{array}{l}23.4 \\
70.0\end{array}$ & $\begin{array}{l}8.0 \\
0.0\end{array}$ & $\begin{array}{l}0.0 \\
0.0\end{array}$ & $\begin{array}{r}-73.9 \\
-147.2\end{array}$ \\
\hline $\begin{array}{l}\text { Total non-PRSP spending } \\
\text { Financing }\end{array}$ & 560.9 & 616.7 & 519.4 & 546.2 & -0.4 \\
\hline $\begin{array}{l}\text { Domestic } \\
\text { External }\end{array}$ & $\begin{array}{l}331.8 \\
229.1\end{array}$ & $\begin{array}{l}488.1 \\
128.6\end{array}$ & $\begin{array}{l}214.7 \\
304.7\end{array}$ & $\begin{array}{l}243.1 \\
303.1\end{array}$ & $\begin{array}{r}-49.5 \\
49.1\end{array}$ \\
\hline Balance & -336.8 & -499.7 & -343.1 & -275.3 & -107.7 \\
\hline $\begin{array}{l}\text { Financing } \\
\text { Net external financing } \\
\text { External resources } \\
\text { Amortization }\end{array}$ & $\begin{array}{l}333.2 \\
434.1 \\
100.9\end{array}$ & $\begin{array}{l}305.7 \\
408.0 \\
102.3\end{array}$ & $\begin{array}{l}368.8 \\
552.9 \\
184.1\end{array}$ & $\begin{array}{l}426.6 \\
609.9 \\
183.3\end{array}$ & $\begin{array}{l}101.5 \\
268.5 \\
167.0\end{array}$ \\
\hline Internal financing & -111.5 & 156.8 & -41.6 & -192.4 & -42.7 \\
\hline Privatization proceeds & 115.1 & 37.2 & 15.9 & 4].1 & -251]$. \\
\hline
\end{tabular}

Sources: Ministry of Finance and Public Credit; and Fund staff estimates.

1/ Cumulative Change Vis-à-vis 2000. 
Figure 1. Nicaragua: External Debt and Debt-Service Indicators for Medium- and Long-Term Public Sector Debt
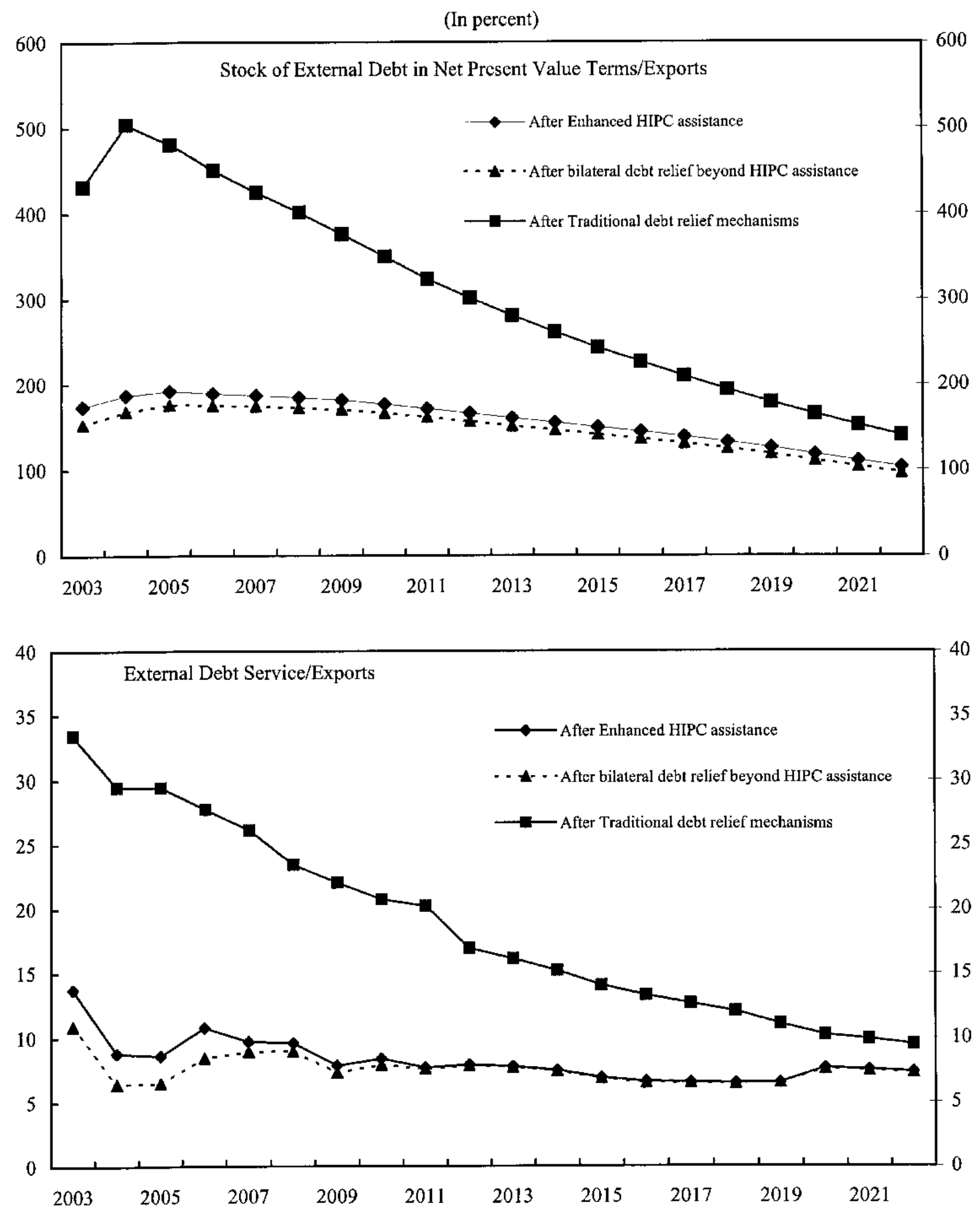

Sources: Nicaraguan authorities; and Bank-Fund staff estimates and projections. 
Figure 2. Nicaragua: Sensitivity Analysis

(In percent)
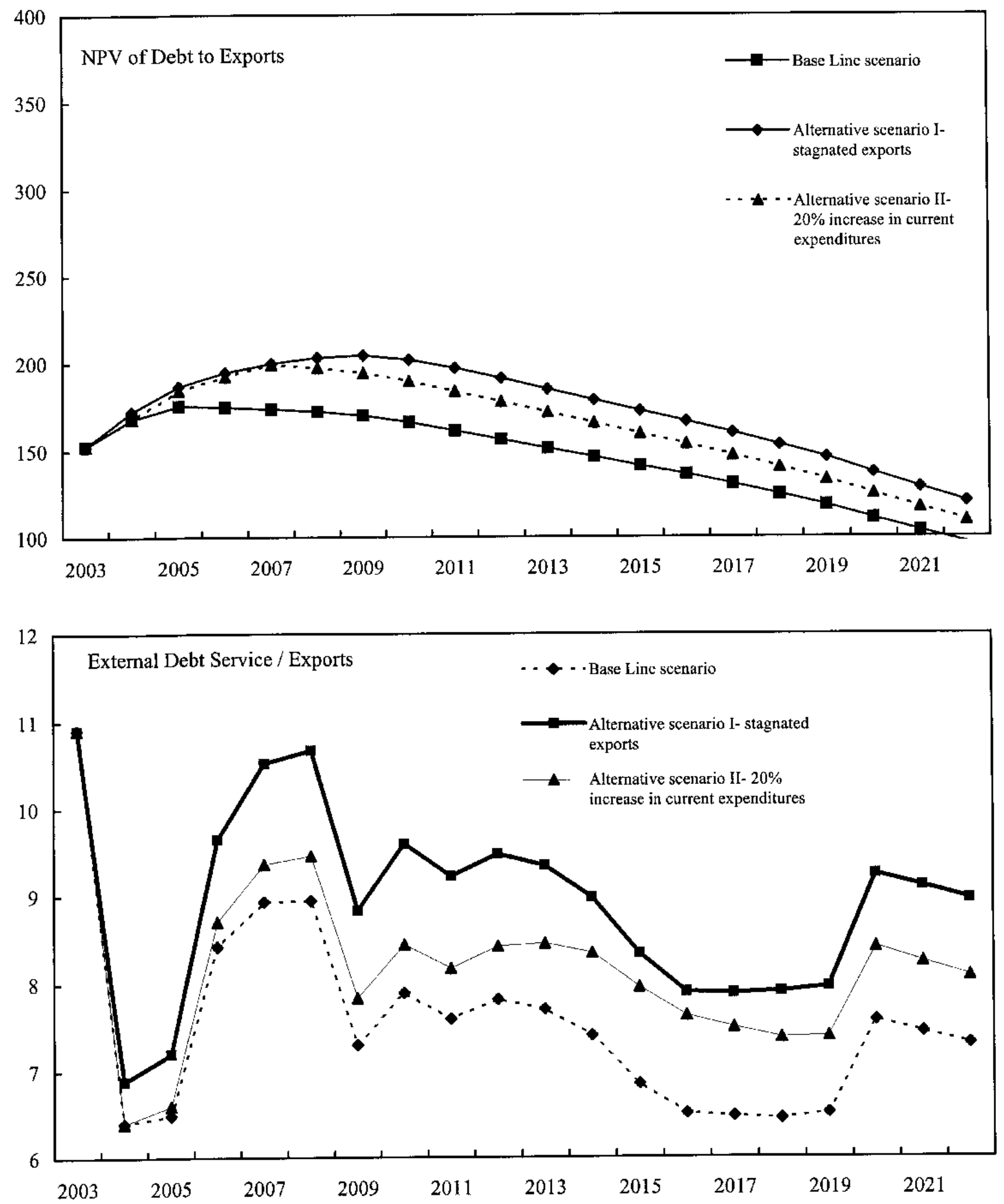

Sources: Nicaraguan authorities; and Bank-Fund staff estimates and projections. 
Table 1. Nicaragua: Medium- and Long-Term Macroeconomic Framework

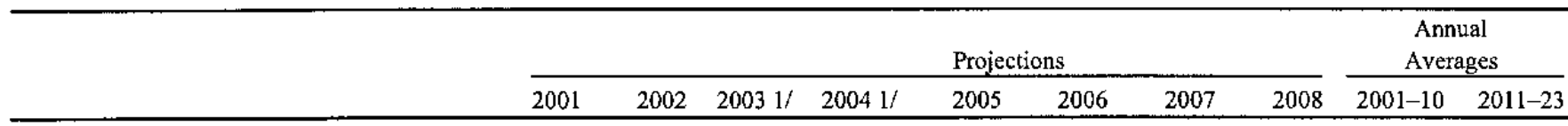

(Annual percentage change)

\section{Output and prices}

Real GDP

GDP deflator (end of period)

$\begin{array}{ll}3.0 & 1.0 \\ 3.9 & 5.3\end{array}$

2.3

6.2

3.7

6.0

(In percent of nominal GDP)

\section{National accounts}

Gross domestic investment

Gross national savings

Combined public sector accounts

Revenue, excluding grants

Grants

Expenditure and net lending

Overall balance

External financing (net)

Domestic financing (net)

\section{Balance of payments}

Exports of goods and services

Imports of goods and services

Current account, excluding official transfers

Current account, including official transfers

Gross official reserves (in months of imports)

$\begin{array}{rrrrrrrrrr}32.1 & 32.1 & 31.5 & 31.0 & 30.8 & 29.9 & 30.9 & 30.3 & 30.6 & 26.2 \\ 9.7 & 10.7 & 13.6 & 15.1 & 16.1 & 16.5 & 18.4 & 18.6 & 15.3 & 19.0\end{array}$

Current account, excluding interest obligations

$19.7 \quad 20.3 \quad 22.1$

$\begin{array}{lll}4.2 & 5.0 & 5.0\end{array}$

$33.0 \quad 30.9 \quad 31.0$

$\begin{array}{lll}-9.2 & -5.7 & -3.9\end{array}$

$\begin{array}{lll}3.8 & 4.2 & 5.2\end{array}$

4.5

1.0

$\begin{array}{rrr}23.1 & 22.9 & 22.8 \\ 49.5 & 49.3 & 4 \\ -24.1 & -19.6 & -17 . \\ -17.9 & -16.4 & -14.6 \\ -15.5 & -11.6 & -9.8 \\ 2.3 & 2.8 & \end{array}$

$\begin{array}{rr}21.9 & 21.5 \\ 3.1 & 3.3 \\ 28.8 & 27.7 \\ -3.8 & -3.0 \\ 5.7 & 4.8 \\ -2.3 & -2.2\end{array}$

\section{1.}

3.4

28.1

$-3.2$

4.0

$-1$.

$-2.3$

$22.8 \quad 23.7$

$48.2 \quad 47.6$

$-17.9$

$-13.9$

24.2
47.9
-13.1

24.4

47.8

$-11.9$

$-10.8$

$-12$.

$-8.5$

2.7

Export volume growth Import volume growth

$\begin{array}{rrr}7.3 & 1.9 & 0.0 \\ 2.5 & -1.2 & -4.3\end{array}$

3.1

(Percentage change)

\begin{tabular}{lllllll}
6.7 & 6.4 & 2.1 & 4.0 & 4.4 & 4.1 & 4.5 \\
3.2 & 4.9 & 4.6 & 3.7 & 3.8 & 2.2 & 2.5 \\
\hline
\end{tabular}

Sources: Central Bank of Nicaragua; and Bank-Fund staff projections.

1/ Baseline program numbers for 2003-04 fiscal framework taken from the Staff Report 10/3/03. 
Table 2. Nicaragua: Medium- and Long-Term Balance of Payments

(In millions of U.S. dollars, unless otherwise noted)

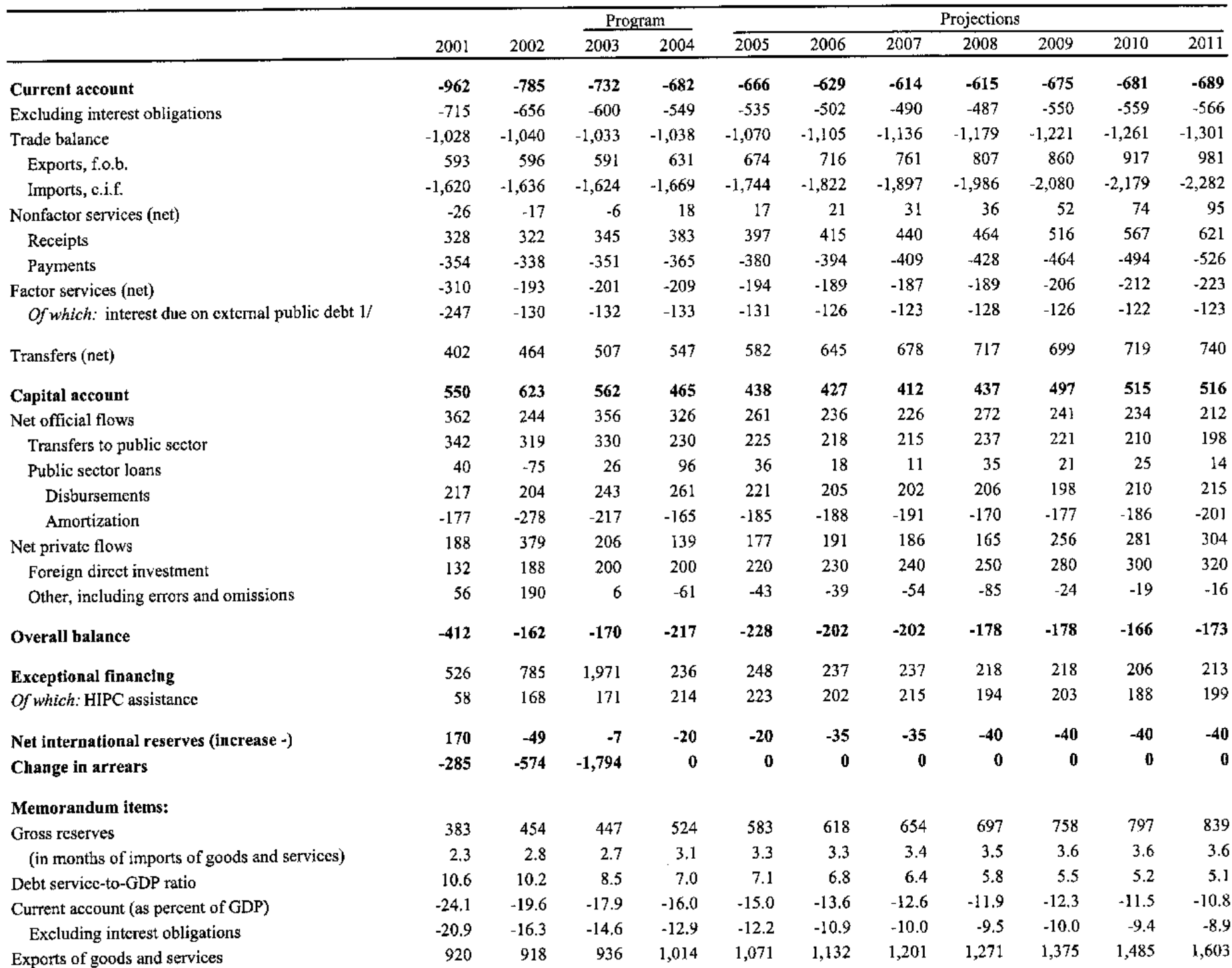


Table 2. Nicaragua: Medium- and Long-Term Balance of Payments (concluded)

(In millions of U.S. dollars, unless otherwise noted)

\begin{tabular}{|c|c|c|c|c|c|c|c|c|c|c|c|c|}
\hline & \multicolumn{12}{|c|}{ Projections } \\
\hline & 2012 & 2013 & 2014 & 2015 & 2016 & 2017 & 2018 & 2019 & 2020 & 2021 & 2022 & 2023 \\
\hline Current account & -696 & -702 & -710 & -722 & -745 & -737 & -751 & -771 & -746 & -727 & -725 & -809 \\
\hline Excluding interest obligations & -575 & -582 & -590 & -604 & -629 & -623 & -640 & -662 & -639 & -621 & -620 & -618 \\
\hline Trade balance & $-1,340$ & $-1,380$ & $-1,421$ & $-1,461$ & $-1,498$ & $-1,534$ & $-1,569$ & $-1,603$ & $-1,635$ & $-1,665$ & $-1,693$ & $-1,718$ \\
\hline Exports, f.o.b. & 1,050 & 1,124 & 1,203 & 1,287 & 1,381 & 1,483 & 1,592 & 1,710 & 1,836 & 1,972 & 2,119 & 2,276 \\
\hline Imports, c.i.f. & $-2,391$ & $-2,504$ & $-2,623$ & $-2,748$ & $-2,880$ & $-3,017$ & $-3,161$ & $-3,312$ & $-3,471$ & $-3,637$ & $-3,812$ & $-3,995$ \\
\hline Nonfactor services (net) & 116 & 139 & 162 & 192 & 198 & 233 & 283 & 316 & 364 & 406 & 458 & 509 \\
\hline Receipts & 676 & 736 & 798 & 874 & 933 & 1,017 & 1,119 & 1,208 & 1,316 & 1,434 & 1,564 & 1,705 \\
\hline Payments & -560 & -597 & -636 & -681 & .735 & -784 & -836 & -892 & -952 & $-1,029$ & $-1,105$ & $-1,195$ \\
\hline Factor services (net) & -232 & -244 & -256 & -270 & -285 & -300 & -317 & -336 & -358 & -380 & -403 & -512 \\
\hline Of which: interest due on external public debt & .121 & -120 & -120 & -118 & -117 & -114 & -111 & -108 & -107 & -106 & -105 & -191 \\
\hline Transfers (net) & -111 & -123 & -136 & -.51 & -168 & -186 & -205 & -227 & -251 & -274 & -298 & -321 \\
\hline Capital account & 567 & 577 & 584 & 596 & 617 & 610 & 626 & 661 & 657 & 638 & 640 & 397 \\
\hline Net official flows & 240 & 220 & 204 & 178 & 152 & 124 & 94 & 79 & 45 & 15 & -14 & -278 \\
\hline Transfers to public sector & 186 & 174 & 162 & 150 & 138 & 126 & 114 & 103 & 82 & 65 & 47 & 34 \\
\hline Public sector loans & 54 & 45 & 42 & 28 & 15 & -2 & -20 & -24 & -37 & -49 & -61 & -312 \\
\hline Disbursements & 225 & 224 & 226 & 213 & 205 & 201 & 195 & 191 & 179 & 183 & 185 & 181 \\
\hline Amortization & -171 & -179 & -184 & -185 & -191 & -202 & -215 & -215 & .216 & -232 & -246 & -493 \\
\hline Net private flows & 327 & 357 & 380 & 418 & 465 & 486 & 532 & 582 & 612 & 623 & 654 & 674 \\
\hline Foreign direct investment & 340 & 360 & 390 & 435 & 485 & 500 & 560 & 610 & 632 & 630 & 635 & 630 \\
\hline Other, including errors and omissions & -13 & -3 & -10 & -17 & -20 & -14 & -28 & -28 & -20 & -7 & 18 & 44 \\
\hline Overall balance & -129 & -125 & -125 & -126 & -128 & -127 & -126 & -110 & -89 & -89 & -85 & -412 \\
\hline Exceptional financing & 169 & 165 & 165 & 166 & 168 & 167 & 166 & 150 & 129 & 129 & 125 & 452 \\
\hline Of which: HIPC assistance & 153 & 149 & 148 & 148 & 148 & 145 & 143 & 124 & 79 & 78 & 74 & 385 \\
\hline Net international reserves (increase -) & -40 & -40 & -40 & -40 & -40 & -40 & -40 & -40 & -40 & -40 & -40 & -40 \\
\hline Change in arrears & $\mathbf{0}$ & $\mathbf{0}$ & $\mathbf{0}$ & $\mathbf{0}$ & $\mathbf{0}$ & $\mathbf{0}$ & $\mathbf{0}$ & $\mathbf{0}$ & $\mathbf{0}$ & $\mathbf{0}$ & 0 & $\mathbf{0}$ \\
\hline \multicolumn{13}{|l|}{ Memorandum items: } \\
\hline Gross reserves & 882 & 928 & 977 & 1,027 & 1,081 & 1,137 & 1,196 & 1,258 & 1,324 & 1,393 & 1,465 & 1,465 \\
\hline (in months of imports of goods and services) & 3.6 & 3.6 & 3.6 & 3.6 & 3.6 & 3.6 & 3.6 & 3.6 & 3.6 & 3.6 & 3.6 & 3,4 \\
\hline Debt service-to-GDP ratio & 4.2 & 4.1 & 3.8 & 3.5 & 3.3 & 3.2 & 3.1 & 2.8 & 2.6 & 2.5 & 2.4 & 4.4 \\
\hline Current account (as percent of GDP) & -10.1 & -9.5 & -8.9 & -8.4 & -8.1 & -7.4 & -7.0 & -6.7 & -6.0 & -5.5 & -5.1 & -5.2 \\
\hline Excluding interest obligations & -8.4 & -7.9 & -7.4 & -7.1 & -6.9 & -6.3 & -6.0 & -5.8 & -5.2 & -4.7 & -3.7 & -5.2 \\
\hline Exports of goods and services & 1,726 & 1,860 & 2,001 & 2,161 & 2,314 & 2,500 & 2,711 & 2,917 & 3,152 & 3,407 & 3,682 & 3,981 \\
\hline
\end{tabular}

Sources: Central Bank of Nicaragua; and Bank-Fund Staff estimates and projections.

1/ Debt service shown before debt relief until 2004; full application of traditional mechanisms assumed thereafter. 
Table 3. Nicaragua: Nominal and Net Present Value of External Debt Outstanding as of End-December 1999 1/

\begin{tabular}{|c|c|c|c|c|}
\hline & \multicolumn{2}{|c|}{ Nominal debt } & \multicolumn{2}{|c|}{$\begin{array}{c}\text { NPV of debt } \\
\text { after rescheduling 2/ }\end{array}$} \\
\hline & From decision point & Revised & From decision point & Revised \\
\hline \multicolumn{5}{|c|}{ ( In millions of U.S. dollars) } \\
\hline Total & 6,412 & 6,956 & 4,523 & 4,542 \\
\hline Multilateral institutions & 2,154 & 2,156 & 1,554 & 1,556 \\
\hline IBRD & 9 & 9 & 10 & 10 \\
\hline IDA & 597 & 597 & 252 & 252 \\
\hline IDB & 885 & 888 & 535 & 537 \\
\hline IMF & 155 & 155 & 113 & 113 \\
\hline CABEI 3/ & 448 & 448 & 603 & 603 \\
\hline FOCEM 4/ & 0 & 0 & 2 & 2 \\
\hline IFAD & 22 & 22 & 12 & 12 \\
\hline Nordic Development Fund & 14 & 14 & 6 & 6 \\
\hline OPEC Fund & 23 & 23 & 21 & 21 \\
\hline Bilateral and commercial & 4,258 & 4,799 & 2,969 & 2,985 \\
\hline Paris Club & 1,625 & 1,633 & 1,205 & 1,194 \\
\hline Australia & 4 & 4 & 1 & 1 \\
\hline Austria & 2 & 2 & 1 & 1 \\
\hline Brazil & 128 & 128 & 42 & 42 \\
\hline Finland & 15 & 15 & 8 & 8 \\
\hline France & 65 & 65 & 48 & 46 \\
\hline Germany & 385 & 385 & 313 & 303 \\
\hline Israel & 1 & 1 & 1 & 1 \\
\hline Italy & 111 & 111 & 60 & 56 \\
\hline Japan & 136 & 136 & 142 & 142 \\
\hline Netherlands & 42 & 42 & 24 & 24 \\
\hline Russia & 371 & 371 & 344 & 344 \\
\hline Spain & 259 & 270 & 181 & 188 \\
\hline Switzerland & 2 & 0 & 2 & - \\
\hline United Kingdom & 2 & 2 & 1 & 1 \\
\hline United States & 102 & 102 & 36 & 36 \\
\hline Non-Paris Club official bilateral & 2,362 & 2,381 & 1,707 & 1,713 \\
\hline Algeria & 76 & 76 & 25 & 25 \\
\hline Bulgaria & 253 & 253 & 83 & 83 \\
\hline China, People's Republic & 25 & 25 & 4 & 4 \\
\hline Costa Rica & 511 & 512 & 511 & 512 \\
\hline Czech Republic & 7 & 7 & 6 & 6 \\
\hline Ecuador & 0 & 2 & 0 & 1 \\
\hline Former Federal Republic of Yugoslavia & 16 & 16 & 5 & 5 \\
\hline Guatemala & 487 & 487 & 486 & 486 \\
\hline Honduras & 142 & 142 & 133 & 133 \\
\hline Hungary & 20 & 21 & 7 & 7 \\
\hline India & 5 & 5 & 2 & 2 \\
\hline Iran & 107 & 119 & 35 & 39 \\
\hline Jaimaica & 0 & 1 & 0 & 0 \\
\hline Libya & 238 & 238 & 78 & 78 \\
\hline Mexico & 64 & 64 & 57 & 57 \\
\hline North Korea & 7 & 7 & 2 & 2 \\
\hline Peru & 31 & 31 & 10 & 10 \\
\hline Poland & 24 & 24 & 8 & 8 \\
\hline Slovak Republic & 81 & 81 & 27 & 27 \\
\hline Taiwan, Province of China & 215 & 215 & 163 & 163 \\
\hline Trinidad and Tobago & 0 & 2 & 0 & 1 \\
\hline Uruguay & 0 & 2 & 0 & 1 \\
\hline Venezuela & 51 & 51 & 65 & 65 \\
\hline Commercial creditors & 271 & 785 & 57 & 78 \\
\hline
\end{tabular}

Sources: Nicaraguan authorities; and Bank-Fund staff estimates.

1/ Public and publicly guaranteed debt only.

2/ After hypothetical full use of traditional debt-relief mechanisms.

3/ NPV of debt before the application of the US\$156 million interim assistance provided by CABEI through the 1997 Debt Relief Agreement.

4/ Previous restructuring eliminated the balance of the debt, leaving only interest payments. NPV of debt is positive due to these future interest payments. 
Table 4. Nicaragua: Estimated Assistance at Decision Point (Amended) 1/

(In millions of U.S. dollars in NPV terms at end-1999, unless otherwise indicated)

\begin{tabular}{|c|c|c|c|c|c|}
\hline & $\begin{array}{c}\text { NPV of } \\
\text { Debt-to-Exports } \\
\text { target }\end{array}$ & \multicolumn{3}{|c|}{ Assistance 2/ } & \multirow{2}{*}{$\begin{array}{l}\text { Common reduction } \\
\text { factor } \\
1999 \text { NPV of debt) }\end{array}$} \\
\hline & (In percent) & Total & Bilateral 3/ & Multilateral & \\
\hline Decision Point & 150 & 3,267 & 2,145 & 1,122 & 72.2 \\
\hline Decision Point (Amended) & 150 & 3,308 & 2,175 & 1,134 & 72.8 \\
\hline \multicolumn{6}{|l|}{ Memorandum items: } \\
\hline NPV of debt at end-1999 2/ & $\ldots$ & 4,542 & 2,985 & 1,556 & $\ldots$ \\
\hline Paris Club & $\ldots$ & $\ldots$ & 1,194 & $\ldots$ & $\ldots$ \\
\hline Non-Paris Club $3 /$ & $\cdots$ & $\cdots$ & 1,713 & $\cdots$ & $\cdots$ \\
\hline Commercial & $\ldots$ & $\ldots$ & 78 & $\ldots$ & $\ldots$ \\
\hline Three-year average of exports (1997-99) & $\cdots$ & 822 & $\cdots$ & $\ldots$ & $\ldots$ \\
\hline NPV of debt-to-exports ratio $4 /$ & $\ldots$ & 552 & $\ldots$ & $\ldots$ & $\cdots$ \\
\hline Targeted NPV & $\ldots$ & 1,233 & $\cdots$ & $\ldots$ & $\cdots$ \\
\hline
\end{tabular}

Sources: Nicaraguan authorities; and Bank-Fund staff estimates.

1/ The proportional burden-sharing approach is described in "HIPC Initiative-Estimated Costs and Burden-sharing Approaches" (the Staff Report, 7/7/97 and IDA/SEC M 97-306, 7/7/97).

2/ Based on latest data available at end-1999 after full application of traditional debt relief mechanisms.

$3 /$ Includes official bilateral and commercial creditors.

4/ In percent of three-year export average. 


$$
-44 \text { - }
$$

Table 5. Nicaragua: External Public and Publicly Guaranteed Debt at End-December 2002 1/

(in millions of U.S. dollars)

\begin{tabular}{|c|c|c|c|c|}
\hline & \multicolumn{2}{|c|}{ Legal Situation $2 f$} & \multicolumn{2}{|c|}{$\begin{array}{c}\text { NPV of Debt } \\
\text { After Full Application of Traditional } \\
\text { Debt Relief 3/ }\end{array}$} \\
\hline & Nominal Debt & NPV of Debt & Nominal Debt & NPV of Debt \\
\hline Total & $6,689.0$ & $5,532.4$ & $5,543.1$ & $4,721.5$ \\
\hline Multilateral & $2,559.9$ & $1,750.0$ & $2,601.3$ & $1,902.9$ \\
\hline IDA & 815.6 & 410.5 & 815.6 & 410.5 \\
\hline IMF & 174.4 & 143.6 & 174.4 & 143.6 \\
\hline $\mathrm{IADB}$ & $1,099.0$ & 751.7 & $1,099.0$ & 751.7 \\
\hline FOCEM & 0.0 & 3.0 & 0.0 & 3.0 \\
\hline NDF & 26.4 & 13.7 & 26.4 & 13.7 \\
\hline CABEI & 390.8 & 388.7 & 432.1 & 541.6 \\
\hline IFAD & 29.6 & 16.8 & 29.6 & 16.8 \\
\hline OPEC & 24.2 & 22.1 & 24.2 & 22.1 \\
\hline Bilateral and commercial & $4,129.1$ & $3,782.4$ & $2,941.8$ & $2,818.6$ \\
\hline Paris Club & $1,301.0$ & $1,066.8$ & $1,392.9$ & $1,279.8$ \\
\hline Australia & 3.6 & 2.5 & 1.2 & 1.2 \\
\hline Austria & 1.3 & 0.8 & 1.8 & 1.4 \\
\hline Brazil & 7.0 & 5.7 & 42.3 & 41.8 \\
\hline Finland & 0.0 & 0.0 & 13.7 & 8.4 \\
\hline France & 61.6 & 58.0 & 47.7 & 48.9 \\
\hline Germany & 353.7 & 272.8 & 373.6 & 336.5 \\
\hline Israel & 1.4 & 1.0 & 1.0 & 0.9 \\
\hline Italy & 90.0 & 59.9 & 99.7 & 72.9 \\
\hline Japan & 112.5 & 120.1 & 112.0 & 120.3 \\
\hline Netherlands & 6.5 & 5.4 & 41.4 & 25.1 \\
\hline Russia & 302.2 & 262.4 & 357.9 & 378.7 \\
\hline Spain & 262.2 & 199.3 & 257.8 & 203.3 \\
\hline Switzcrland & 0.0 & 0.0 & 0.0 & 0.0 \\
\hline United Kingdom & 1.5 & 1.0 & 1.1 & 1.1 \\
\hline United States & 97.3 & 77.9 & 41.6 & 39.1 \\
\hline Non-Paris Club official bilateral & $1,873.8$ & $1,761.2$ & $1,510.8$ & $1,500.5$ \\
\hline Algeria & 99.2 & 99.2 & 25.0 & 24.8 \\
\hline Bulgaria & 35.1 & 29.9 & 83.5 & 82.7 \\
\hline China, People's Republic & 16.6 & 16.1 & 16.8 & 4.1 \\
\hline Costa Rica & 562.0 & 562.0 & 511.4 & 511.4 \\
\hline Czech Republic & 5.1 & 5.5 & 5.1 & 5.5 \\
\hline Ecuador & 1.6 & 1.0 & 0.5 & 0.5 \\
\hline Former Federal Republic of Yugoslavia & 17.5 & 17.5 & 5.4 & 5.3 \\
\hline Guatemala & 141.7 & 90.1 & 363.5 & 363.5 \\
\hline Honduras & 164.2 & 164.2 & 71.8 & 71.8 \\
\hline Hungary & 23.6 & 23.6 & 6.8 & 6.7 \\
\hline India & 5.4 & 5.4 & 1.5 & 1.5 \\
\hline Iran & 136.0 & 136.0 & 39.4 & 39.0 \\
\hline Jamaica & 0.6 & 0.4 & 0.2 & 0.2 \\
\hline Libya & 258.6 & 258.6 & 78.5 & 77.8 \\
\hline Mexico & 39.4 & 31.4 & 39.4 & 38.4 \\
\hline North Korea & 7.0 & 7.0 & 2.3 & 2.2 \\
\hline Peru & 34.9 & 34.8 & 10.4 & 10.3 \\
\hline Poland & 27.1 & 27.1 & 8.1 & 8.0 \\
\hline Slovak Republic & 50.6 & 4.3 & 26.8 & 26.5 \\
\hline South Korea & 1.8 & 1.2 & 0.0 & 0.0 \\
\hline Taiwan, Province of China & 214.6 & 188.7 & 186.9 & 165.8 \\
\hline Trinidad and Tobago & 1.5 & 1.1 & 0.6 & 0.6 \\
\hline Uruguay & 2.4 & 2.4 & 0.7 & 0.7 \\
\hline Venezuela & 27.4 & 53.9 & 26.3 & 53.1 \\
\hline Commercial creditors & 954.3 & 954.3 & 38.0 & 38.3 \\
\hline
\end{tabular}

Sources: Nicaraguan authorities; and Bank-Fund staff estimates.

1/ Figures are based on data at end-2002.

2/ Reflects the external debt situation as of end-2002, and includes the 1995 and 1998 Naples flows and a Cologne flow rescheduling starting in September 2002, 100 percent debt cancellation from Finland and the Netherlands; rescheduling from Brazil, Bulgaria, Guatemala and the Siovak Republic. 3/ After full use of traditional debt relief mechanisms including for non-Paris Club members. 
Table 6. Comparison of Discount Rate and Exchange Rate Assumptions

\begin{tabular}{|c|c|c|c|c|}
\hline & \multicolumn{2}{|c|}{$\begin{array}{c}\text { Discount Rates } 1 / 2 / \\
\text { (In percent per annum) }\end{array}$} & \multicolumn{2}{|c|}{$\begin{array}{c}\text { Exchange Rates } 2 / \\
\text { (U.S. dollar per currency) }\end{array}$} \\
\hline & $\begin{array}{c}\text { At decision } \\
\text { point } \\
\text { End-1999 } \\
\end{array}$ & $\begin{array}{l}\text { At completion } \\
\text { point } \\
\text { End-2002 }\end{array}$ & $\begin{array}{c}\text { At decision } \\
\text { point } \\
\text { End-1999 }\end{array}$ & $\begin{array}{l}\text { At completion } \\
\text { point } \\
\text { End-2002 } \\
\end{array}$ \\
\hline \multicolumn{5}{|l|}{ Currency } \\
\hline United States dollar & 7.04 & 5.12 & 1.00 & 1,00 \\
\hline Domestic currency & 7.04 & 4.82 & 0.08 & 0.07 \\
\hline Special Drawing Right & 5.59 & 4.82 & 1.37 & 1.36 \\
\hline CFA franc & 5.59 & 5.55 & 0.0015 & 0.0016 \\
\hline Euro & 5.47 & 5.55 & 1.00 & 1.05 \\
\hline Austrian shillings & 5.47 & 5.55 & 0.07 & 0.08 \\
\hline Belgian franc & 5.47 & 5.55 & 0.02 & 0.03 \\
\hline Canadian dollar & 6.67 & 5.88 & 0.69 & 0.63 \\
\hline Swiss franc & 4.27 & 3.42 & 0.63 & 0.72 \\
\hline Deutsche mark & 5.47 & 5.55 & 0.51 & 0.54 \\
\hline Danish kroner & 5.32 & 5.78 & 0.14 & 0.14 \\
\hline Spanish peseta & 5.47 & 5.55 & 0.01 & 0.01 \\
\hline Finnish markaa & 5.47 & 5.55 & 0.17 & 0.18 \\
\hline French franc & 5.47 & 5.55 & 0.15 & 0.16 \\
\hline Pound sterling & 6.70 & 5.84 & 1.62 & 1.61 \\
\hline Japanese yen & 1.98 & 1.75 & 0.01 & 0.01 \\
\hline Norwegian kroner & 6.64 & 7.76 & 0.12 & 0.14 \\
\hline Netherland guilder & 5.47 & 5.55 & 0.46 & 0.48 \\
\hline Swedish kroner & 5.80 & 6.11 & 0.12 & 0.11 \\
\hline Venezuelan bolivar & 5.59 & 4.82 & 0.0015 & 0.0007 \\
\hline Indian rupee & 5.59 & 4.82 & 0.02 & 0.02 \\
\hline IDB unit of account & 5.59 & 4.82 & 1.55 & 1.52 \\
\hline
\end{tabular}

Sources: OECD; and IMF, International Financial Statistics.

1/ The discount rates used are the average commercial interest reference rates (CIRRs) for the respective currencies over the six-month period ending in December 2002 for the completion point and in December 1999 for the decision point.

2/ For all currencies for which the CIRRs are not available, the SDR discount rate is used as a proxy. 
Table 7. Nicaragua: Comparison of Net Present Value of External Public Debt Between Decision Point and Completion Point

(In millions of U.S. dollars, unless otherwise indicated)

\begin{tabular}{|c|c|c|c|c|}
\hline & \multicolumn{4}{|c|}{ Stock at end-2002 } \\
\hline & \multirow{2}{*}{$\begin{array}{c}\text { Decision Point DSA } \\
\text { (Projection) 1/ } \\
\text { After enhanced } \\
\text { debt relief }\end{array}$} & \multicolumn{3}{|c|}{ Completion Point DSA 2/ } \\
\hline & & $\begin{array}{l}\text { After traditional } \\
\text { debt relief }\end{array}$ & $\begin{array}{l}\text { After enhanced } \\
\text { debt relief } 3 /\end{array}$ & $\begin{array}{l}\text { After additional } \\
\text { bilateral relicf } 4 /\end{array}$ \\
\hline NPV of debt using end-Dccember 1999 parameters & 1,320 & 4,402 & 1,380 & 1,164 \\
\hline Multilateral & 747 & 1,667 & 654 & 654 \\
\hline Official bilateral and commercial & 574 & 2,735 & 726 & 510 \\
\hline NPV of debt using end-Deccmber 2002 parameters & $\ldots$ & 4,722 & 1,502 & 1,291 \\
\hline Multilateral & $\cdots$ & 1,903 & 766 & 766 \\
\hline Official bilateral and commercial & $\cdots$ & 2,819 & 736 & 526 \\
\hline \multicolumn{5}{|l|}{ NPV of debt-to-exports ratio $5 / 6$} \\
\hline Using end-December 1999 parameters & 128 & $\ldots$ & $\ldots$ & $\ldots$ \\
\hline Using end-December 2002 parameters & $\cdots$ & 507 & 161 & 139 \\
\hline \multicolumn{5}{|l|}{ Exports of goods and services $7 /$} \\
\hline Decision point & 1,031 & $\cdots$ & $\cdots$ & $\cdots$ \\
\hline Completion point & $\ldots$ & 931 & 931 & 931 \\
\hline
\end{tabular}

Sources: Nicaraguan authorities; and Bank-Fund staff estimates.

1/ Debt sustainability analysis (DSA) based on stock of debt reconciled as of end-December 1999, assuming full (hypothetical) delivery of enhanced HIPC assistance.

2/ Based on stock of debt reconciled as of end-2002.

3/ Assuming full (hypothetical) delivery of enhanced HIPC assistance at end-2002.

4/ Assuming full (hypothetical) delivery of enhanced HIPC assistance at end-2002, and debt relief beyond that granted under the enhanced HIPC Initiative

on a voluntary basis.

5/ Based on the average of three consecutive years of exports of goods and services ending in the current year.

6/ The value of assistance under the enhanced HIPC framework was determined at its December 2000 decision point, namely, US $\$ 3,268$ million in NPV terms, using end-1999 parameters (exchange rates and discount factors). The corresponding values for enhanced HIPC rclicf expressed as of end-2002 are provided for information only.

7/ Averagc of three consecutive years of exports of goods and services ending in the current year. Data and projections at the time of the decision and completion points under the enhanced

HIPC framework. 
Table 8. Nicaragua: Net Present Value of External Debt

(In millions of U.S. dollars, unless otherwise indicated)

\begin{tabular}{|c|c|c|c|c|c|c|c|c|c|c|c|c|c|c|c|}
\hline & \multirow{2}{*}{$\begin{array}{r}\text { Actuals } \\
2002\end{array}$} & \multicolumn{12}{|c|}{ Projections } & \multicolumn{2}{|c|}{ Averages } \\
\hline & & 2003 & 2004 & 2005 & 2006 & 2007 & 2008 & 2009 & 2010 & 2011 & 2012 & 2017 & 2022 & $2002-12$ & $2013-22$ \\
\hline \multicolumn{16}{|l|}{ l. After traditional debt-relief mechanisms $1 /$} \\
\hline 1. NPV of total debt $(2+6) 2 /$ & $4,721.5$ & $4,731.3$ & $4,810.0$ & $4,837.0$ & $4,820.1$ & $4,810.1$ & $4,817.6$ & $4,816.3$ & $4,816.9$ & $4,804.3$ & $4,828.7$ & $4,870.6$ & $4,785.3$ & $4,801.2$ & $4,844.4$ \\
\hline 2. NPV of outstanding debt $(3+4)$ & $4,72 t .5$ & $4,576.3$ & $4,462.6$ & $4,329.5$ & $4,185.3$ & $4,047.1$ & $3,921.4$ & $3,795.2$ & $3,675.1$ & $3,548.3$ & $3,458.0$ & $2,933.0$ & $2,320.7$ & $4,065.5$ & $2,862.3$ \\
\hline 3. Official bilateral and commercial & $2,818.6$ & $2,689.6$ & $2,597.5$ & $2,508.6$ & $2,424.0$ & $2,354.2$ & $2,282.1$ & $2,204.7$ & $2,124.4$ & $2,034.0$ & $1,984.0$ & $1,658.7$ & $1,264.6$ & $2,365.6$ & $1,611.7$ \\
\hline Paris Club & $1,279.8$ & $1,174.9$ & $1,102.3$ & $1,030.7$ & 961.2 & 910.5 & 858.4 & 804.7 & 749.2 & 681.5 & 655.1 & 469.1 & 264.4 & 928.0 & 445.6 \\
\hline Other official bilateral and commercial & $1,538.8$ & $1,514.7$ & $1,495.3$ & $1,477.9$ & $1,462.8$ & $1,443.8$ & $1,423.7$ & $1,400.0$ & $1,375.2$ & $1,352.6$ & $1,328.9$ & $1,189.7$ & $1,000.2$ & $1,437.6$ & $1,166.1$ \\
\hline 4. Multilateral & $1,902.9$ & $1,886.7$ & $1,865.1$ & $1,820.9$ & $1,761.3$ & $1,692.9$ & $1,639.3$ & $1,590.6$ & $1,550.6$ & $1,514,3$ & $1,474,1$ & $1,274.2$ & $1,056.1$ & $1,699.9$ & $1,250.5$ \\
\hline IDA & 410.5 & 419.3 & 426.6 & 432.8 & 437.8 & 442.7 & 446.5 & 447.4 & 447.1 & 446.3 & 442.6 & 404.8 & 322.0 & 436.3 & 391.0 \\
\hline IMF & 143.6 & 141.9 & 131.8 & 111.6 & 85.1 & 57.5 & 29.0 & 10.5 & 3.6 & 1.8 & 0.0 & 0.0 & 0.0 & 65.1 & 0.0 \\
\hline IDB & 751.7 & 746.1 & 742.7 & 731.8 & 716.6 & 699.4 & 680.1 & 653.0 & 624.1 & 594.2 & 563.8 & 422,5 & 310.4 & 682.1 & 415.4 \\
\hline Others & 597.2 & 579.5 & 563.9 & 544.7 & 521.8 & 493.4 & 483.6 & 479.7 & 475.9 & 471.9 & 467.7 & 446.9 & 423.6 & 516.3 & 444.2 \\
\hline 5. Nominal stock of total debt & $5,543.1$ & $5,636.1$ & $5,798.7$ & $5,873.1$ & $5,890.3$ & $5,900.9$ & $5,935.4$ & $5,955.6$ & $5,979.5$ & $5,992.4$ & $6,045.3$ & $6,164.9$ & $5,971.9$ & $5,868.2$ & $6,107.0$ \\
\hline \multicolumn{16}{|l|}{ 11. After enhanced IUPC assistance } \\
\hline 1. NPV of total debt $(2+6) 2 /$ & $5,607.5$ & $5,773.6$ & $1,787.6$ & $1,934.6$ & $2,022.3$ & $2,117.6$ & $2,213.8$ & $2,324.8$ & $2,431.6$ & $2,547.6$ & $2,661.9$ & $3,217,3$ & $3,525.9$ & $2,856.6$ & $3,217,3$ \\
\hline NPV of total debt after fult delivery $3 /$ & $1,501.9$ & $1,606.0$ & $1,787.6$ & $1,934.6$ & $2,022.3$ & $2,117.6$ & $2,213.8$ & $2,324.8$ & $2,431.6$ & $2,547.6$ & $2,661.9$ & $3,217.3$ & $3,525.9$ & $2,104.5$ & $3,217.3$ \\
\hline Multilateral & 765.6 & 903.1 & $1,072.8$ & $1,220.5$ & $1,315.3$ & $1,397.5$ & $1,479.6$ & $1,580.8$ & $1,678.9$ & $1,774.7$ & $1,869.4$ & $2,364.6$ & $2,732.0$ & $1,368.9$ & $2,384,5$ \\
\hline Bilateral & 736.3 & 702.9 & 714.7 & 714.1 & 707.0 & 720.1 & 734.2 & 744.0 & 752.7 & 772.9 & 792.5 & 852.7 & 793.8 & 735.6 & 832.8 \\
\hline 2. NPV of outstanding dcbt $(3+4)$ & $5,607.5$ & $5,618.6$ & $1,440.2$ & $1,427.0$ & $1,387.5$ & $1,354.7$ & $1,317.6$ & $1,303.8$ & $1,289.8$ & $1,291.6$ & $1,291.1$ & $1,279.6$ & $1,061.2$ & $2,120.9$ & $1,235.1$ \\
\hline 3. Official bilateral and commercial & $3,911.6$ & $3,890.3$ & 654.5 & 632.6 & 605.1 & 597.6 & 590.4 & 580.8 & 570.4 & 571.2 & 570.4 & 536.4 & 411.4 & $1,197.7$ & 513.5 \\
\hline Paris Club & $1,221.8$ & $1,223.5$ & 145.3 & 124.4 & 98.1 & 92.6 & 87.2 & 81.8 & 76.4 & 76.7 & 77.0 & 78.3 & 75.8 & 300.4 & 77.7 \\
\hline Other official bilateral and commercial & $2,689.8$ & $2,666.8$ & 509.2 & 508.2 & 507.1 & 505.0 & 503.2 & 499.1 & 494.0 & 494.5 & 493.4 & 458.1 & 335.6 & 897.3 & 435.8 \\
\hline 4. Multilateral & $1,695.8$ & $1,728.3$ & 785.7 & 794.5 & 782.4 & 757.0 & 727.2 & 722.9 & 719.5 & 720.5 & 720.7 & 743.2 & 649.9 & 923.1 & 721.7 \\
\hline $\mathrm{IDA}$ & 402.1 & 418.9 & 213.0 & 220.3 & 227.7 & 235.3 & 242.7 & 249.0 & 254.3 & 259.2 & 263.9 & 288.8 & 304.1 & 271.5 & 289.1 \\
\hline IMF & 141.1 & 141.9 & 42.8 & 44.8 & 41.2 & 31.6 & 20.4 & 10.5 & 3.6 & 1.8 & 0.0 & 0.0 & 0.0 & 43.6 & 0.0 \\
\hline IDB & 712.5 & 744.3 & 337.8 & 341.8 & 330.8 & 312.4 & 291.6 & 296.5 & 300.4 & 304.3 & 308.7 & 349.8 & 310.4 & 389.2 & 338.4 \\
\hline Others & 440.2 & 423.2 & 192.1 & 187.5 & 182.7 & 177.7 & 172.5 & 167.0 & 161.2 & 155.1 & 148.2 & 104.6 & 35.4 & 218.8 & 94.1 \\
\hline 5. Nominal stock of total debt & $6,741.8$ & $6,894.2$ & $3,729.7$ & $3,890.9$ & $3,979.2$ & $4,080.9$ & $4,189.2$ & $4,273.1$ & $4,362.9$ & $4,460.1$ & $4,554.5$ & $4,919.6$ & $4,924.2$ & $4,650.6$ & $4,874.0$ \\
\hline \multicolumn{16}{|c|}{ III. After bilateral debt relief beyond HIPC assistance 4/ } \\
\hline I. NPV of total debt $(2+6) 2 /$ & $4,557.9$ & $4,745.9$ & $1,606.8$ & $1,768.0$ & $1,874.3$ & $1,971.9$ & $2,069.9$ & $2,181.8$ & $2,289.2$ & $2,400.1$ & $2,508.8$ & $3,032,4$ & $3,301.0$ & $2,543.1$ & $3,026.9$ \\
\hline NPV of total debt after full delivery $3 /$ & $1,291.2$ & $1,411.0$ & $1,606.8$ & $1,768.0$ & $1,874.3$ & $1,971.9$ & $2,069.9$ & $2,181.8$ & $2,289.2$ & $2,400.1$ & $2,508.8$ & $3,032.4$ & $3,301.0$ & $1,943.0$ & $3,026.9$ \\
\hline Multilateral & 765.6 & 903.1 & $1,072.8$ & $1,220.5$ & $1,315.3$ & $1,397,5$ & $1,479.6$ & $1,580.8$ & $1,678.9$ & $1,774.7$ & $1,869.4$ & $2,364.6$ & $2,732.0$ & $1,368.9$ & $2,384.5$ \\
\hline Bilateral & 525.6 & 507.9 & 534.0 & 547.5 & 559.0 & 574.4 & 590.3 & 600.9 & 610.3 & 625.4 & 639.5 & 667.8 & 568.9 & 574.1 & 642.5 \\
\hline 2. NPV of outstanding debt $(3+4)$ & $4,557.9$ & $4,590.9$ & $1,259.4$ & $1,260.5$ & $1,239.6$ & $1,209.0$ & $1,173.7$ & $1,160.7$ & $1,147.4$ & $1,144.1$ & $1,138.1$ & $1,094.8$ & 836.3 & $1,807.4$ & $1,044.8$ \\
\hline 3. Official bilateral and commercial & $2,862.0$ & $2,862.6$ & 473.7 & 466.0 & 457.1 & 452.0 & 446.4 & 437.8 & 427.9 & 423.6 & 417.4 & 351.6 & 186.4 & 884.2 & 323.2 \\
\hline Paris Club & $1,066.8$ & $1,089.0$ & 35.1 & 29.6 & 23.2 & 22.1 & 20.9 & 19.8 & 18.6 & 18.3 & 18.0 & 15.7 & 12.7 & 214.7 & 15.3 \\
\hline Other official bilateral and commercial & $1,795.2$ & $1,773.6$ & 438.7 & 436.4 & 433.9 & 429.9 & 425.5 & 418.1 & 409.3 & 405.3 & 399.4 & 335.8 & 173.8 & 669.6 & 307.8 \\
\hline 4. Multilateral & $1,695.8$ & $1,728.3$ & 785.7 & 794.5 & 782.4 & 757.0 & 727.2 & 722.9 & 719.5 & 720.5 & 720.7 & 743.2 & 649.9 & 923.1 & 721.7 \\
\hline 5. Nominal stock of total debt & $5,764.9$ & $5,933.7$ & $3,437.3$ & $3,607.8$ & $3,710.2$ & $3,809.7$ & $3,915.2$ & $3,995.8$ & $4,082.0$ & $4,170.5$ & $4,255.9$ & $4,592.2$ & $4,576.4$ & $4,243.9$ & $4,544.5$ \\
\hline \multicolumn{16}{|l|}{ Memorandum items: } \\
\hline 6. NPV of new borrowing & $\cdots$ & 155.0 & 347.4 & 507.5 & 634.8 & 762.9 & 896.2 & $1,021.0$ & $1,141.8$ & $1,256,0$ & $1,370.7$ & $1,937.6$ & $2,464.6$ & 809.3 & $1,982.1$ \\
\hline Official bilateral & $\ldots$ & 27.6 & 60.2 & 81.5 & 101.9 & 122.4 & 143.8 & 163.1 & 182.4 & 201.8 & 222.1 & 316.3 & 382.5 & 130.7 & 319.3 \\
\hline Multilateral & $\ldots$ & 127.4 & 287.1 & 426.0 & 532.9 & 640.5 & 752.4 & 857.9 & 959.4 & $1,054.2$ & $1,148.6$ & $1,621.4$ & $2,682.2$ & 678.7 & $1,662.8$ \\
\hline
\end{tabular}

Sources: Nicaraguan authorities; and Bank-Fund staff cstimates and projections.

1/ Refcrs to public and publicly guaranteed external debt only and assumes a stock-of-dcbt operation on Naples terms (67 percent NPV reduction) at the cnd of 1999 , and at least comparable action by other official bilatcral creditors. 2/ Discounted on the basis of the average commercial interest reference rate for the respective currency, derived over the six-month period prior to the latest date for which actual data arc available (December 2002).

3/ NPV of total debt assuming the entite HIPC Initiative assistance is fully delivered as of end-2002.

4/ After debt relief beyond HIPC offered by some of the Paris Club creditors and nonParis Club creditors on a voluntary basis. 
Table 9. Nicaragua: Extemal Debt Service After Full Implementation of Debt-Relief Mechanisms (In millions of U.S. dollars, unless otherwisc indicatcd)

\begin{tabular}{|c|c|c|c|c|c|c|c|c|c|c|c|c|c|c|c|}
\hline & & & & & & & & & & & & & & \multicolumn{2}{|c|}{ Annual Averages } \\
\hline & 2003 & 2004 & 2005 & 2006 & 2007 & 2008 & 2009 & 2010 & 2011 & 2012 & 2013 & 2018 & 2023 & $2003-12$ & $2013-23$ \\
\hline Total debt service & 312.7 & 298.5 & 315.2 & 314.0 & 313.8 & 297.8 & 303.0 & 307.7 & 323.7 & 291.6 & 299.2 & 326.3 & 683.9 & 307.8 & 318.6 \\
\hline After traditional debt-relief mechanisms 1 ; & 310.5 & 293.0 & 306.8 & 301.7 & 298.3 & 279.1 & 273.3 & 261.1 & 261.8 & 219.0 & 215.7 & 223.9 & 522.7 & 280.5 & 213.8 \\
\hline Multilatcral & 106.1 & 114.6 & 136.1 & 149.3 & 155.3 & 137.1 & 129.6 & 118.4 & 112.9 & 115.0 & 109.8 & 105.4 & 490.0 & 127.4 & 105.7 \\
\hline IDA & 11.1 & 12.9 & 14.5 & 15.9 & 16.3 & 17.5 & 20.6 & 21.9 & 22.4 & 25.2 & 25.5 & 31.4 & 35.2 & 17.8 & 31.5 \\
\hline IMF & 8.6 & 16.9 & 26.5 & 31.9 & 31.7 & 31.2 & 20.0 & 7.4 & 1.9 & 1.9 & 0.0 & 0.0 & 0.0 & 17.8 & 0.0 \\
\hline DB & 42.5 & 40.1 & 47.4 & 51.3 & 52.6 & 53.8 & 60.8 & 61.3 & 60.8 & 59.8 & 56.6 & 47.4 & 35.7 & 53.0 & 47.2 \\
\hline Others & 43.9 & 44.7 & 47.6 & 50.2 & 54.6 & 34.6 & 28.2 & 27.8 & 27.8 & 28.0 & 27.8 & 26.6 & 419.1 & 38.7 & 26.9 \\
\hline Official bilateral & 204.5 & 178.3 & 170.7 & 152.4 & 143.0 & 142.0 & 143.7 & 142.7 & 148.9 & 104.0 & 105.9 & 118.4 & 32.7 & 153.0 & 108.1 \\
\hline Paris Club & 151.3 & 131.1 & 126.5 & 111.8 & 98.8 & 97.8 & 96.9 & 96.1 & 105.8 & 61.0 & 62.9 & 76.0 & 28.7 & 107.7 & 64.2 \\
\hline Of which: ODA & 20.9 & 21.5 & 20.4 & 19.3 & 18.0 & 17.8 & 17.6 & 17.4 & 17.2 & 17.0 & 16.9 & 16.0 & 10.2 & 18.7 & 15.4 \\
\hline Other official bilateral and commercial & 53.2 & 47.2 & 44.2 & 40.6 & 44.1 & 44.2 & 46.8 & 46.6 & 43.1 & 43.0 & 42.9 & 42.4 & 4.0 & 45.3 & 43.9 \\
\hline Total debt service & 128.6 & 89.0 & 92.2 & 121.7 & 116.4 & 122.1 & 108.0 & 124.4 & 123.2 & 136.3 & 144.5 & 175.6 & 292.6 & 116.2 & 189.4 \\
\hline After enhanced HIPC assistance & 126.4 & 83.5 & 83.9 & 109.5 & 100.9 & 103.4 & 78.4 & 77.7 & 61.3 & 63.7 & 61.0 & 73.2 & 131.5 & 88.9 & $\mathbf{8 4 . 5}$ \\
\hline Multilateral & 27.6 & 28.2 & 29.9 & 51.2 & 63.9 & 67.1 & 40.1 & 39.1 & 34.4 & 35.2 & 30.8 & 32.4 & 69.6 & 41.7 & 43.0 \\
\hline IDA & 2.6 & 2.8 & 3.0 & 3.2 & 3.4 & 4.0 & 5.4 & 6.7 & 7.3 & 7.9 & 7.9 & 9.1 & 16.4 & 4.6 & 9.7 \\
\hline IMF & 6.0 & 7.5 & 0.0 & 5.8 & 11.5 & 12.7 & 10.9 & 7.4 & 1.9 & 1.9 & 0.0 & 0.0 & 0.0 & 6.6 & 0.0 \\
\hline DB & 3.3 & 3.4 & 12.5 & 27.8 & 34.7 & 36.1 & 9.5 & 10.6 & 10.9 & 10.7 & 8.5 & 6.5 & 35.7 & 15.9 & 16.6 \\
\hline Others & 15.7 & 14.6 & 14.4 & 14.4 & 14.4 & 14.2 & 14.3 & 14.3 & 14.3 & 14.8 & 14.5 & 16.8 & 17.5 & 14.5 & 16.6 \\
\hline Official bilateral & 98.8 & 55.3 & 54.0 & 58.4 & 36.9 & 36.3 & 38.3 & 38.7 & 26.9 & 28.5 & 30.2 & 40.8 & 61.9 & 47.2 & 41.6 \\
\hline Paris Club & 59.0 & 28.2 & 26.9 & 31.3 & 9.0 & 8.7 & 8.4 & 8.1 & 2.1 & 2.2 & 2.2 & 2.5 & 4.1 & 18.4 & 2.7 \\
\hline Of which: ODA & 21.7 & 2.9 & 2.9 & 3.1 & 2.3 & 2.3 & 2.3 & 2.3 & 2.1 & 2.1 & 2.1 & 2.4 & 3.9 & 4.4 & 2.6 \\
\hline Other official bilateral and commercial & 39.7 & 27.1 & 27.1 & 27.1 & 27.9 & 27.6 & 29.8 & 30.5 & 24.8 & 26.3 & 28.0 & 38.3 & 57.8 & 28.8 & 38.8 \\
\hline Total debt service & 102.1 & 64.8 & 69.4 & 95.3 & 107.2 & 113.7 & 100.4 & 117.2 & 121.7 & 134.9 & 143.3 & 174.8 & 279.5 & 102.7 & 187.8 \\
\hline After bilateral debt relief beyond HIPC $2 /$ & 99.9 & 59.3 & 61.1 & 83.1 & 91.7 & 95.0 & 70.8 & 70.6 & 59.9 & 62.3 & 59.8 & 72.4 & 118.3 & 75.3 & 83.0 \\
\hline Multilateral & 27.6 & 28.2 & 29.9 & 51.2 & 63.9 & 67.1 & 40.1 & 39.1 & 34.4 & 35.2 & 30.8 & 32.4 & 69.6 & 41.7 & 43.0 \\
\hline Official bilateral & 72.3 & 31.1 & 31.2 & 31.9 & 27.7 & 27.9 & 30.6 & 31.5 & 25.4 & 27.1 & 29.0 & 40.0 & 48.7 & 33.7 & 40.0 \\
\hline Paris Club & 30.3 & 7.2 & 7.3 & 7.9 & 2.3 & 2.3 & 2.2 & 2.2 & 1.2 & 1.2 & 1.3 & 1.4 & 1.5 & 6.4 & 1.3 \\
\hline Of which: ODA & 15.1 & 0.5 & 0.5 & 0.5 & 0.5 & 0.5 & 0.5 & 0.5 & 0.6 & 0.6 & 0.6 & 0.8 & 1.3 & 2.0 & 0.8 \\
\hline Other official bilateral and commercial & 42.0 & 23.9 & 23.9 & 24.0 & 25.4 & 25.6 & 28.4 & 29.3 & 24.2 & 25.8 & 27.7 & 38.5 & 47.2 & 27.3 & 38.7 \\
\hline \multicolumn{16}{|l|}{ Memorandum items: } \\
\hline Debt service of new debt & 2.2 & 5.5 & 8.3 & 12.2 & 15.6 & 18.7 & 29.6 & 46.6 & 61.8 & 72.6 & 83.5 & 102.4 & 161.2 & 27.3 & 104.8 \\
\hline Multilatcral & 1.4 & 3.8 & 6.0 & 9.3 & 12.1 & 14.8 & 23.1 & 37.2 & 50.5 & 59.4 & 68.4 & 77.6 & 126.2 & 21.8 & 80.9 \\
\hline Official bilateral & 0.8 & 1.8 & 2.3 & 2.9 & 3.4 & 4.0 & 6.5 & 9.4 & 11.4 & 13.3 & 15.1 & 24.8 & 35.0 & 5.6 & 23.9 \\
\hline \multicolumn{16}{|l|}{ Nominal HIPC relief } \\
\hline Under the enhanced HIPC initiative & 184.2 & 209.5 & 223.0 & 192.2 & 197.4 & 175.7 & 195.0 & 183.4 & 200.5 & 155.3 & 154.7 & 150.6 & 391.2 & 191.6 & 153.1 \\
\hline
\end{tabular}

Sources: Nicaraguan authorities; and Bank-Fund staff estimates and projections.

1/ Assumes a stock-of-debt opcration on Naplcs terms (67 percent NPV reduction) at the cnd of 1999, and at lcast comparable action by other bilatcral creditors.

2/ After dcbt relief beyond HIPC offered by some of the Paris Club creditors and nonParis Club creditors. 
Table 10. Nicaragua: External Debt Indicators (In percent, unless otherwise indicated)

\begin{tabular}{|c|c|c|c|c|c|c|c|c|c|c|c|c|c|c|c|c|c|c|c|c|c|c|c|}
\hline & \multirow{2}{*}{$\begin{array}{r}\text { Actuals } \\
2002\end{array}$} & \multicolumn{20}{|c|}{ Projections } & \multicolumn{2}{|c|}{ Averages } \\
\hline & & 2003 & 2004 & 2005 & 2006 & 2007 & 2008 & 2009 & 2010 & 2011 & 2012 & 2013 & 2014 & 2015 & 2016 & 2017 & 2018 & 2019 & 2020 & 2021 & 2022 & 2002-2011 & $2012-2022$ \\
\hline \multicolumn{24}{|l|}{ After traditlonal debe rellef mechaniswos $2 /$} \\
\hline NPV of debt-to-GDP ratio & 117.9 & 97.2 & 112.7 & 109.1 & 103.9 & 98.6 & 93.6 & 87.4 & 81.2 & 75.3 & 70.3 & 65.6 & 61.1 & 56.9 & 52.9 & 49.1 & 45.4 & 42.1 & 39.0 & 36.1 & 33.4 & 97.7 & 50.2 \\
\hline NPV of debt-to-exports ratio $3 / 4 /$ & 507.0 & 431.0 & 503.6 & 480.4 & 449.6 & 424.0 & 401.0 & 375.5 & 349.8 & 323.0 & 300.9 & 280.2 & 261.1 & 242.8 & 225.9 & 209.5 & 193.4 & 178.7 & 165.0 & 152.2 & 140.2 & 424.5 & 213.6 \\
\hline NPV of debt-to-sevenue ratio $5 t$ & 582.6 & 439.6 & 513.7 & 508.5 & 480.1 & 449.9 & 423.8 & 395.5 & 367.6 & 340.5 & 315.3 & 294.0 & 274.1 & 255.2 & 237.3 & 217.3 & 201.1 & 186.4 & 172.8 & 159.9 & 146.5 & 450.2 & 223.6 \\
\hline Debt service-to-exports ratio & $\cdots$ & 33.4 & 29.4 & 29.4 & 27.7 & 26.1 & 23.4 & 22.0 & 20.7 & 20.2 & 16.9 & 16.1 & 15.2 & 14.0 & 13.3 & 12.6 & 12.0 & 11.1 & 10.2 & 9.9 & 9.5 & 25.8 & 12.8 \\
\hline Debt scrvice-to-revenue ratio $5 /$ & $\cdots$ & 34.5 & 31.9 & 33.1 & 31.3 & 29.4 & 26.2 & 24.9 & 23.5 & 22.9 & 19.0 & 18.2 & 17.1 & 15.9 & 14.9 & $14 . t$ & 13.5 & 12.4 & 11.5 & 11.2 & 10.7 & 28.6 & 14.4 \\
\hline \multicolumn{24}{|l|}{ After enhanced HIPC assistance } \\
\hline NPV of debt-to-GDP ratio & 140.1 & 140.8 & 41.8 & 43.6 & 43.6 & 43.4 & 43.0 & 42.2 & 41.0 & 39.9 & 38.8 & 37.5 & 36.3 & 35.0 & 33.8 & 32.4 & 31.0 & 29.6 & 27.9 & 26.2 & 24.6 & 62.0 & 32.1 \\
\hline NPV of debt-to-exports ratio $3 / 4 /$ & 602.1 & 624.4 & 187.0 & 192.1 & 188.6 & 186.6 & 184.3 & 181.3 & 176.6 & 1713 & 165.9 & 160.3 & 155.0 & 149.4 & 144.2 & 138.4 & 132.1 & 125.7 & 117.8 & 110.5 & 103.3 & 269.4 & 136.6 \\
\hline NPV of dcht-to-cxports ratio (existing debt only) & 602.1 & 607.6 & 150.7 & 141.7 & 129.4 & 119.4 & 109.7 & 101.7 & 93.7 & 86.8 & 80.5 & 74.8 & 69.5 & 64.3 & 59.6 & 55.0 & 50.6 & 46.2 & 40.8 & 35.8 & 31.1 & 214.3 & 55.3 \\
\hline NPV of dete-to-expons ratio affer full delivery in $20013 / 4 / 6 /$ & 161.3 & 173.7 & 187.0 & 192.1 & 188.6 & 186.6 & 184.3 & 181.3 & 176.6 & 177.3 & 165.9 & 160.3 & 155.0 & 149.4 & 144.2 & 138.4 & I32.I & 125.7 & H17.8 & 10.5 & 103.3 & 180.3 & 136.6 \\
\hline NPV of debl-so-revenuc ratio $5 t$ & 691.9 & 619.7 & 153.7 & 150.0 & 138.2 & 126.7 & 115.9 & 107.1 & 98.4 & 91.6 & 84.3 & 78.5 & 72.9 & 67.6 & 62.6 & 57.1 & 52.6 & 48.2 & 42.7 & 37.6 & 32.5 & 229.3 & 57.9 \\
\hline Debt service-to-exports ratio & $\cdots$ & 13.7 & 8.8 & 8.5 & 50.8 & 9.7 & 9.6 & 7.9 & 8.4 & 7.7 & 7.9 & 7.8 & 7.5 & 6.9 & 6.6 & 6.5 & 6.5 & 6.5 & 7.7 & 7.5 & 7.4 & 9.5 & 7.2 \\
\hline Debt service-to-revenue ratio $5 /$ & $\cdots$ & 14.2 & 9.5 & 9.7 & 12.1 & 10.9 & 10.7 & 8.9 & 9.5 & 8.7 & 8.9 & 8.8 & 8.4 & 7.8 & 7.4 & 7.3 & 7.3 & 7.3 & 8.6 & 8.5 & 8.3 & 10.5 & 8.1 \\
\hline \multicolumn{24}{|l|}{ After butateral debt relief beyond HIPC assistance $6 / 77$} \\
\hline NPV of debt-to-GDP ratio & 113.9 & 115.8 & 37.6 & 39.9 & 40.4 & 40.4 & 40.2 & 39.6 & 38.6 & 37.6 & 36.5 & 35.4 & 34.2 & 33.0 & 31.8 & 30.6 & 29.2 & 27.9 & 26.2 & 24.6 & 23.0 & 54.4 & 30.2 \\
\hline NPV of debt-wo-exports ratio $3 / 4 /$ & 489.4 & 513.3 & 168.1 & 175.6 & 174.8 & 173.8 & 172.3 & 170.1 & 166.2 & 161.3 & 156.4 & 151.2 & 146.2 & 140.9 & 133.9 & 130.4 & 124.4 & 118.2 & 110.7 & 103.6 & 96.7 & 236.5 & 128.6 \\
\hline NPV of debt-to-exports ratio (existing debt only) & 489.4 & 496.5 & 131.8 & 125.2 & 115.6 & 106.6 & 97.7 & 90.5 & 83.3 & 76.9 & 70.9 & 65.6 & 60.6 & 55.8 & 51.4 & 47.1 & 42.9 & 38.8 & 33.7 & 28.9 & 24.5 & 181.3 & 47.3 \\
\hline$N P V$ of deht-to-expors ratio affer full delivery in $20013 / 4 / 6 \mathrm{~s}$ & 138.6 & 152.6 & 168.1 & 175.6 & 174.8 & 173.8 & 172.3 & 170.1 & 166.2 & 161.3 & 156.4 & 151.2 & 146.2 & 140.9 & 135.9 & 130.4 & I24.4 & 188.2 & 110.7 & 103.6 & 96.7 & 165.4 & 128.6 \\
\hline NPV of debt-to-revenue ratio $5 t$ & 362.4 & 523.5 & 171.5 & 185.9 & 186.7 & 184.4 & 182.1 & 179.2 & 174.7 & 170.2 & 163.8 & 158.6 & 153.4 & 148.1 & 142.8 & 135.3 & 125.4 & 123.4 & 115.9 & 108.8 & 101.1 & 252.0 & 134.6 \\
\hline Debr servicc-to-exporls ratio & ... & 10.9 & 6.4 & 6.5 & 8.4 & 8.9 & 8.9 & 7.3 & 7.9 & 7.6 & 7.8 & 7.7 & 7.4 & 6.8 & 6.5 & 6.5 & 6.4 & 6.5 & 7.6 & 7.4 & 7.3 & 8.1 & 7.1 \\
\hline Debt service-to-revenue ratio $5 /$ & $\cdots$ & 11.3 & 6.9 & 7.3 & 9.5 & 10.0 & 10.0 & 8.2 & 8.9 & 8.6 & 8.8 & 8.7 & 8.3 & 7.7 & 7.3 & 7.2 & 7.2 & 73 & 8.5 & 8.4 & 8.2 & 9.0 & 8.0 \\
\hline \multicolumn{24}{|l|}{ Menorandum items (in millions of U.S. dollars): } \\
\hline NPV of debt after enhanced HIPC assistance & 5,6075 & $5,773.6$ & 1,787.6 & $1,934.6$ & $2,022.3$ & $2,117.6$ & $2,213.8$ & 2.324 .8 & $2,431.6$ & $2,547.6$ & $2,661,9$ & $2,773.6$ & $2,887.1$ & $2,999.5$ & $3,111.9$ & $3,217.3$ & 3.313 .5 & 3.405 .2 & 3.448 .9 & $3,489.6$ & $3,525.9$ & $2,876.1$ & $3,166.8$ \\
\hline Of which: existing debt only & $5,607.5$ & 5.618 .6 & $1,440.2$ & 1.427 .0 & 1.387 .5 & $1,354.7$ & $1,317.6$ & $1,303.8$ & $1,289.8$ & $1,291.6$ & $1,291.1$ & $1,293.3$ & $1,293.5$ & 1,291.2 & $1,286.4$ & $1,279.6$ & $1,269.0$ & $\mathbf{1}, 252.7$ & 1.194 .2 & $5,130.1$ & $1,061.2$ & $2,203.8$ & $1,240.2$ \\
\hline Debt service after tonhanevd HiPC assistance & $\cdots$ & 128.6 & 89.0 & 92.2 & 121.7 & $\$ 16.4$ & 122.1 & 108.0 & 124.4 & 123.2 & 136.3 & 144.5 & 149.6 & 149.1 & 152.6 & $\$ 63.2$ & 175.6 & 190.1 & 241.6 & 256.2 & 271.2 & 114.0 & 184.5 \\
\hline Debt scrvice beyond HIPC assistance & $\ldots$ & 102.1 & 64.8 & 69.4 & 95.3 & 107.2 & 113.7 & 100.4 & 117.2 & 121.7 & 134.9 & 143.3 & $\$ 48.1$ & 148.0 & 150.6 & 161.8 & 174.8 & 190.0 & 238.8 & 253.6 & 269.2 & 99.1 & 183.0 \\
\hline GDP & $4,003.2$ & $4,099.4$ & $4,271.6$ & 4,433.5 & $4,637.5$ & $4,876.6$ & $5,145.0$ & $5,509.8$ & 5.929 .9 & $6,382.0$ & $6,868.7$ & $7,392.4$ & $7,956.1$ & $8,562.7$ & $9,215.6$ & 9,918.3 & $10,674.6$ & $11,488.5$ & $12,364.5$ & $13,307.3$ & $14,322.0$ & 4.928 .8 & $10,188.2$ \\
\hline Exports of goods and services $3 /$ & 917.9 & 936.0 & $1,013.6$ & $1,070.9$ & 1.131.9 & $1,200.8$ & $1,271.4$ & $1,375.3$ & $1,484.8$ & $1,602.5$ & $1,726.4$ & $1,860.2$ & $2,000.7$ & 2,160.7 & $2,314.2$ & 2.499 .5 & $2,710.8$ & $2,917.2$ & $3,152.3$ & $3,406,8$ & $3,682.4$ & $1,200.5$ & 2.584 .7 \\
\hline Exports of goods and services (three-year mvg. Avg.) 3/ & 931.3 & 924.7 & 955.8 & $1,006.8$ & 1,072.1 & 1,134.5 & $1,201.3$ & $1,282.5$ & 1.377 .1 & $1,487.5$ & $1,604.6$ & $1,729.7$ & 1.862 .5 & $2,007.2$ & $2,158.6$ & $2,324.8$ & 2,508.2 & $2,709.2$ & $2,926.8$ & $3,158.8$ & 3,413.8 & $1,137.4$ & $2,400.4$ \\
\hline Government Revezue 5/ & 810.4 & 906.6 & 937.0 & 951.1 & $1,003.9$ & $1,069.1$ & $1,136,8$ & $1,217.7$ & 1.310 .5 & $1,410.4$ & $1,531.7$ & $1,648.5$ & $1,774.2$ & $1,909.5$ & $2,055.1$ & 2.241 .5 & $2,412.5$ & 2.596 .4 & 2.794 .4 & $3,007.5$ & $3,265.4$ & $1,075.4$ & $2,294.2$ \\
\hline
\end{tabular}

Sourres: Nicaraguan authorities; and Bank-Fund staff estimates and projections.

1/ All debt indicators refer to public and publicly graranteed debt and ree defined after rescheduling, unless otherwise indicated.

$2 /$ Reflect a hypothetical stock-uff-dcbl uperation on Naples terms at end-1999 for Paris Club crediturs as calculated in the HIPC Decision Point Document (www.imf.org).

3/As defined in IMF, Balance of Paymentis Manual Sth editivn, 1993.

4/ Based on a three-year average of exports on the previous year (e.g., export average aver 2000-2002 for NPV of deb-to-exports ratio in 2002).

$5 /$ Revenue is defined as central guvernment revenue, excluding grantes.

6/ Assuming full delivery of HIPC assistance at end-2002.

$7 /$ Reflects additional debt relief provided by the Paris Cluh creditors and nunParis Club creditors beyond the requirenents of the enhanced HIPC assistance. 
NPV of debl-10-exponts rativ 2

Debt service-to-exports ratio

Debt service-to-revenue ratio $3 t$

Menorandum items (in millisns ur U.S. defllars. NPV of debt

Of which: new deb

Debt service

Of which: new debt

Exports of goods and setvices, three-year average

Exports of goods and services, annual

\section{Afternative scemarlo 14 ;}

NPV of debt-to-exports ratio

Debt service-to-exports ratio

Debt service-to-revenue ratio $2 f$

Memorandum iterns (in millions of U.S. donlars)

NPV of debt

Of which: new deb

Debt service

of which: new debt

Exports of goods and services, three-year average

ds and services, annuar

\section{Alteraative secnario II 5}

DrV or debi to exports ratio $2 /$

Debt service to exports ratio $2 /$

Memorandum itenss: (in millions of U.S. dollars): NPV of debr

Of which: new deb

Debt service

Of which: new debt

Exports of goods and services, threc-year average

Exporss of goods and services, anru

\begin{tabular}{|c|c|c|c|c|c|c|c|c|c|c|c|c|c|c|c|c|c|c|c|c|c|}
\hline 52.6 & 168.1 & 175.6 & 174.8 & 173.8 & 172.3 & 170.1 & 166.2 & 161.3 & 156.4 & 151.2 & 146.2 & 140.9 & 135.9 & 130.4 & 124.4 & 188.2 & 110.7 & 103.6 & 96,7 & 167,1 & 125.8 \\
\hline 11.3 & 6.9 & 7.3 & 9.5 & 10.0 & 10.0 & 8.2 & 8.9 & 8.6 & 8.8 & 8.7 & 8.3 & 7.7 & 7.3 & 7.2 & 7.2 & 7.3 & 8.5 & 8.4 & 8.2 & 9.0 & 1.9 \\
\hline & & & & & & & & & & & & & & & 8.0 & & & & & & \\
\hline 1.0 & 06.8 & & 74,3 & 171.9 & $2,069.9$ & $2,181.8$ & & 400.1 & $2,508.8$ & & & $\{27.8$ & 934.1 & & $3,120.7$ & 203.3 & , 240.1 & 273.3 & & & 026.9 \\
\hline 102.1 & 64.8 & 69.4 & 95.3 & 107.2 & 113.7 & 100.4 & 117.2 & 121.7 & 134.9 & 143.3 & 148.1 & 148.0 & 150.6 & 161.8 & 174.8 & 190.0 & 238.8 & 253.6 & 269.2 & 102.7 & 187.8 \\
\hline 2.2 & 5.5 & 8.3 & & i5.6 & 18.7 & 29.6 & 6.6 & & 72.6 & & 86.4 & 83.5 & 84.6 & 93.5 & 102.4 & 111.7 & 121.9 & 133.8 & 147.2 & 27.3 & 104.8 \\
\hline 924.7 & 955.8 & $1,006,8$ & $1,072.1$ & $1,134.5$ & 201.3 & $1,282.5$ & $1,377.1$ & 487.5 & $1,604.6$ & $1,729.7$ & $1,862.5$ & 2,0072 & $2,158.6$ & $2,324.8$ & $2,508.2$ & $2,709.2$ & $2,926.8$ & $3,158.8$ & $3,413.8$ & $1,204.7$ & $2,480.0$ \\
\hline 936.0 & $1,013.6$ & 70.9 & L131 & 00.8 & 271.4 & 1,375 & & & & & & & & & & $2,917.2$ & $3,152.3$ & $3,406.8$ & $3,682.4$ & $2 \times 1.4$ & $2,670.5$ \\
\hline
\end{tabular}

\section{U. Sensitivity anslysis}

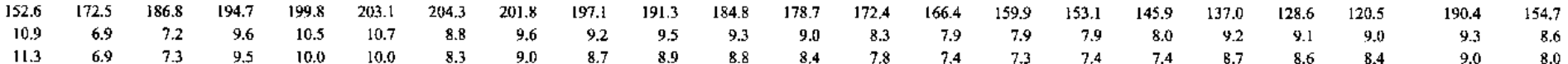

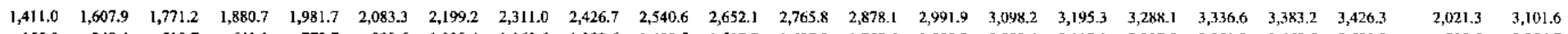

$\begin{array}{llllllllllllllllllllll}155.0 & 348.4 & 510.7 & 641.1 & 772.7 & 909.6 & 1,038.4 & 1,163.6 & 1,282.6 & 1,402.5 & 1,517.7 & 1,637.3 & 1,758.6 & 1,883.3 & 2,003.4 & 2,119.1 & 2,237.3 & 2,351.2 & 2,469.5 & 2,590.0 & 822.5 & 2,056.7\end{array}$

$\begin{array}{llllllllllllllllllllll}102.1 & 64.9 & 69.5 & 95.4 & 107.4 & 114.0 & 100.7 & 117.7 & 122.3 & 135.7 & 144.3 & 149.5 & 149.7 & 152.7 & 164.3 & 177.7 & 193.4 & 242.8 & 258.3 & 274.9 & 103.0 & 190.8\end{array}$

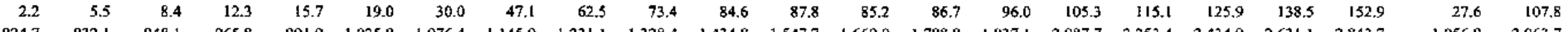

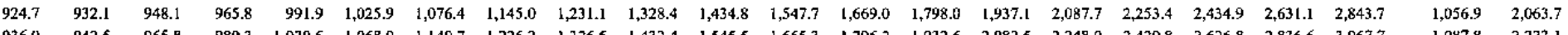

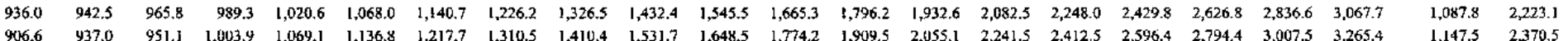

$\begin{array}{llllllllllllllllllllll}152.6 & 168.1 & 184.4 & 192.3 & 199.3 & 197.3 & 194.4 & 189.7 & 183.8 & 177.9 & 171.8 & 165.8 & 159.5 & 153.6 & 147.2 & 140.3 & 133.3 & 125.0 & 117.2 & 109.7 & 184.0 & 142.3\end{array}$

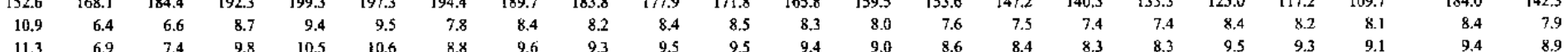

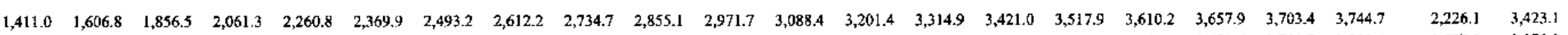

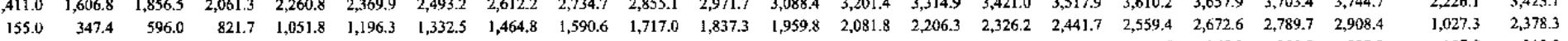

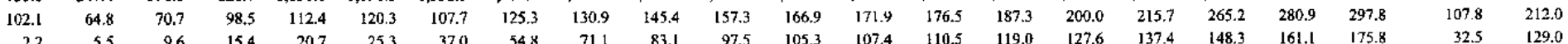

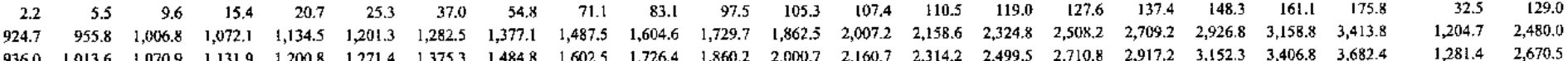

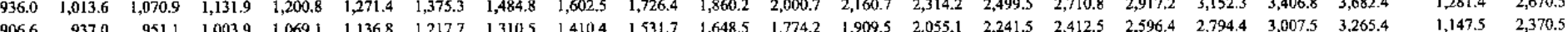

Sources: Nicaraguan authorities; atd Bank-Fund staff estimates and projections.

I/All debt indicaturs refier wo public and publicly guaranteed debt and are defined after rescheduling, unless otherwise indicated.

2/ Exports of goods and services as defined in IMF, Balance of Payments Manual, 5th edition, 1993; excludes transil trade. The NPV of debl-toexports ratio is based on a backward three-year average of exports; the debt-service ratio is based on current exports. $3 /$ Revenues are defined as central government revenues, excluding grants.

4/ Scenario I assumes stagnant expons from 2004 to 2007 with baseline growth ratc thereafter.

$5 /$ Scenario II assures a 20 percent increse in current expenditures between 2005 and 2007 . 
Table 12. Nicaragua: Status of Creditor Participation Under Enhanced HIPC Initiative

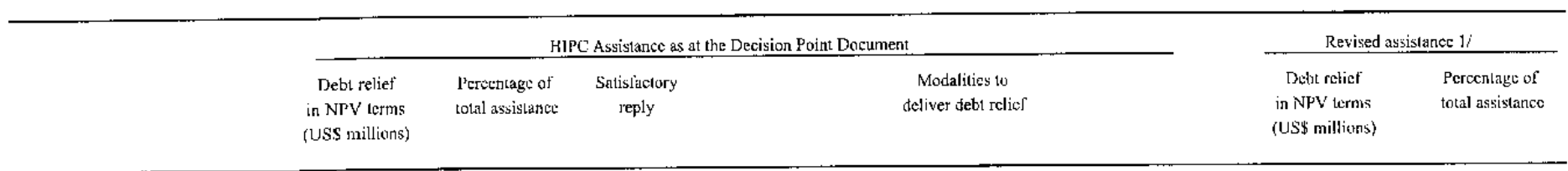

IDA

IMF

IDB 2

IFAT

OPEC Fund

NFD

CABEI

435.2

13.3

Yes

FOCEM

1.7

0.1

No
Intcrim assistance is being prowided cquivalent to a 90 percent reduction on Nicaragua's debts scrviet to IDA. After completion poirl, assistance will be providecl in the same manner, providing a cusıulative noninal assistance of US\$379.2 nillion in romital tems.

IMF assistance will be delivered through grants from the PRGF/HIPC Trust Fund to an escrow accoant. Thesc resources, plus accrued interest, would be use 10 reduce the payments talling due to IMF during 2002-09 on Nicaragua's obligations as of August 2000. Total debt service silvings ate cxpected to amount US\$81.5 million in NPV (SDR 59.3), of which SDR2.6 million was provided as interim assistance through Oetober 2003.
190.9 service payments to the IaDB over the period Jnnuary 2001-December 2019, un tistrursed and outstanding debt as of end-Decenber 1999. Total NPV assistance will amount to US $\$ 387.9$ million, out of which US\$88.4 million has already been provided as interim assistance.
Assistance will be delivered at the complction point, through a reduction of debt service payments con cligible debt by up to 100 percent until the target in NPV terms is reached. Preliminary estimates show that IFAD's relief could be delivered over 14 ycars.

Full assistance will be provided through three concessiona loans which resources will be used to refinatec the arrears lowards the OPEC. Fund and to rriet the payments to the Fund until the resources are exhausted. Total assistantice is cxpected to amount USS14.9 million.
Assistance will be delivered at the completion point, through reduction of debt service payments on eligible debt by up to 100 gercent until the larget in NPV terms is reached. Preliminary estimates show that iFD's rellief could be delivered over 11 years.

A total of US $\$ 233.8$ million in interim assistance has been providut hy CABEI. After completion point, the rest of the assistanec will be provided through a partial cancelation of patyments gutstanding and the rescheduling of the remaining debt over 20 years

Assistance will be provided after completion point cquivalernt to a 80.8 percent reduction on the interest payznents due to FOCEM on the $z$ ero coupon. 
Table 12. Nicaragua: Status of Creditor Participation Under Enhanced HIPC Initiative (concluded)

\begin{tabular}{|c|c|c|c|c|c|c|}
\hline & \multicolumn{4}{|c|}{ HIPC assistance as estimated in the Decision Point Document } & \multirow[b]{2}{*}{$\begin{array}{l}\text { Debt relief } \\
\text { in NPV terms } \\
\text { (US\$ millions) }\end{array}$} & \multirow[b]{2}{*}{$\begin{array}{l}\text { Percentage of } \\
\text { total assistance }\end{array}$} \\
\hline & $\begin{array}{l}\text { Debt relief } \\
\text { in NPV terms } \\
\text { (USS millions) }\end{array}$ & $\begin{array}{l}\text { Pcrecntage of } \\
\text { total assistance }\end{array}$ & $\begin{array}{l}\text { Satisfactory } \\
\text { reply }\end{array}$ & $\begin{array}{c}\text { Modalities to } \\
\text { dcliver debt relief }\end{array}$ & & \\
\hline Paris Club Creditors & 869.1 & 26.6 & Yes & $\begin{array}{l}\text { Interim assistance is provided through Cologne term flow relief } \\
\text { and most of the creditors have cancelled } 100 \text { percent of flow } \\
\text { during the interim period. The government of the Netherlands } \\
\text { and Finland cancelled } 190 \text { percent of their outstanding debts } \\
\text { and the remaining Paris Club crcditors will deliver the rest of } \\
\text { the relief at the completion point. }\end{array}$ & 869.8 & 26.3 \\
\hline Non-Paris Club Creditors & $1,232,6$ & 37.7 & & & $1,248.1$ & 37.7 \\
\hline Algeria & 17.9 & 0.5 & No & & 18.1 & 0.5 \\
\hline Bulgaria & 59.8 & 1.8 & Yes & $\begin{array}{l}\text { Assistance was provided through a stock opcration agreed in } \\
\text { June } 2002 \text {. The stock opcration provided a relief beyond the } \\
\text { enhanced HIPC requirements. }\end{array}$ & 60.3 & 1.8 \\
\hline China, People's Republic & 2.8 & 0.1 & No & & 2.9 & 0.1 \\
\hline Costa Rica & 369.2 & 11.3 & No & & 373.0 & 11.3 \\
\hline Czech Republic & 4.4 & 0.1 & Yes & $\begin{array}{l}\text { Assistance provided in } 1995 \text { through a stock operation was } \\
\text { considered to be sufficient at the decision point. }\end{array}$ & 4.4 & 0.1 \\
\hline Ecuador & & & No & $\begin{array}{l}\text { This debt was not included at decision point. The creditor } \\
\text { provided some relief though a stock operation in } 2002 \text {. }\end{array}$ & 0.4 & 0.0 \\
\hline Guatemala & 351.0 & 10.7 & Yes & $\begin{array}{l}\text { Cesce - Spain took over the debt beld by Cesce - Guatemala. } \\
\text { The assistance was provided through a stock operation agreed } \\
\text { in } 2001 \text {. The stock operation provided a relief beyond the } \\
\text { cnhanced HIPC requirements. }\end{array}$ & 354.0 & 10.7 \\
\hline Honduras & 96.4 & 3.0 & No & & 97.1 & 2.9 \\
\hline Hungary & 4.8 & 0.1 & $\mathrm{No}$ & & 4.9 & 0.1 \\
\hline India & 1.2 & 0.0 & $\mathrm{Na}$ & & 1.2 & 0.0 \\
\hline Iran & 25.4 & 0.8 & $\mathrm{Na}$ & & 28.4 & 0.9 \\
\hline Jamaica & & & No & $\begin{array}{l}\text { This debt was not included at decision point. The creditor } \\
\text { provided some relief through a stock operation in } 2001 \text {. }\end{array}$ & 0.1 & 0.0 \\
\hline Libya & 56.2 & 1.7 & No & & 56.7 & 1.7 \\
\hline Mexico & 40.9 & 1.3 & Yes & $\begin{array}{l}\text { Assistance provided in } 1996 \text { through a stock operation was } \\
\text { considered to be sufficient at the decision point. }\end{array}$ & 41,3 & 1.2 \\
\hline North Korea & 1.6 & 0.0 & No & & 1.6 & 0.0 \\
\hline Peru & 7.5 & 0.2 & No & & 7.5 & 0.2 \\
\hline Poland & 5.8 & 0.2 & No & & 5.8 & 0.2 \\
\hline Slavak Republic & 19.2 & 0.6 & Yes & $\begin{array}{l}\text { Assistance was provided through a stock operation agrecd in } \\
2000 \text {. The gtock operation provided a relief beyond the } \\
\text { enhanced HIPC tequirements. }\end{array}$ & 19.3 & 0.6 \\
\hline Taiwan, Province of China & 118.1 & 3.6 & No & & 119.1 & 3.6 \\
\hline Trinidad and Tobago & & & No & $\begin{array}{l}\text { This debt was not included at decision point. The creditor } \\
\text { provided some relief through a stock operation in } 2002 \text {. }\end{array}$ & 0.4 & 0.0 \\
\hline Uruguay & & & No & $\begin{array}{l}\text { This debt was not included at decision point. The creditor } \\
\text { provided some relief through a stock operation in } 2002 \text {. }\end{array}$ & 0.5 & 0.0 \\
\hline Venezuela & 46.6 & 1.4 & No & & 47.0 & 1.4 \\
\hline Yugoslavia, Former Federal Rep. & 3.9 & 0.1 & No & & 3.9 & 0.1 \\
\hline Commercial creditors & 41.2 & 1.3 & No & & 56.9 & 1.7 \\
\hline Total bilateral and commercial & 2,143 & 65.6 & & & 2,175 & 65.7 \\
\hline TOTAL & 3,267 & 100.0 & & & 3,308 & 100.0 \\
\hline
\end{tabular}

Sources: Nicaraguan authorities; and Bank-Fund staff estimates.

1/ Assistance revised at Completion Point.

2 Includes the US $\$ 1.7$ million loan reclassification from bilateral creditors (Swiss Fund) 10 multilateral creditors (IDB). 
Table 13. Nicaragua: Delivery of IDA Assistance Under the Enhanced HIPC Initiative 1/

(In millions of U.S. dollars, unless otherwise indicated)

\begin{tabular}{|c|c|c|c|c|c|c|c|c|c|c|c|c|c|c|c|}
\hline & \multirow[b]{2}{*}{2001} & \multirow[b]{2}{*}{2002} & \multicolumn{10}{|c|}{ Projections } & \multicolumn{3}{|c|}{ Cumulative } \\
\hline & & & 2003 & 2004 & 2005 & 2006 & 2007 & 2008 & 2009 & 2010 & 2015 & 2023 & $2002-10$ & $2011-23$ & $2001-2023$ \\
\hline Debt service before HIPC assistance $1 /$ & 6.8 & 9.8 & 11.1 & 12.9 & 14.5 & 15.9 & 16.3 & 17.5 & 20.6 & 21.9 & 28.7 & 35.2 & 147.3 & 398.1 & 545.4 \\
\hline Principal & 1.8 & 4.4 & 4.9 & 6.8 & 8.5 & 9.9 & 10.4 & 11.8 & 14.9 & 16.3 & 23.9 & 32.1 & 89.8 & 340.8 & 430.6 \\
\hline Interest & 5.0 & 5.4 & 6.1 & 6.1 & 6.0 & 5.9 & 5.9 & 5.8 & 5.7 & 5.6 & 4.9 & 3.1 & 57.5 & 57.2 & 114.7 \\
\hline Deb1 service after HIPC assistance & 1.2 & 1.7 & 2.6 & 2.8 & 3.1 & 3.4 & 3.5 & 4.1 & 5.5 & 6.9 & 8.4 & 16.6 & 34.7 & 131.4 & 166.1 \\
\hline Principal & 0.0 & 0.0 & 0.5 & 0.7 & 0.9 & 1.2 & 1.4 & 2.0 & 3.4 & 4.8 & 6.6 & 15.0 & 15.0 & 108.9 & 123.9 \\
\hline Interest & 1.2 & 1.7 & 2.1 & 2.1 & 2.1 & 2.1 & 2.1 & 2.1 & 2.1 & 2.1 & 1.8 & 1.6 & 19.7 & 22.5 & 42.3 \\
\hline Savings on debt service to IDA & 5.7 & 8.1 & 8.4 & 10.1 & 11.4 & 12.5 & 12.8 & 13.4 & 15.1 & 15.0 & 20.3 & 18.6 & 112.6 & 266.7 & 379.3 \\
\hline Principal & 1.8 & 4.3 & 4.5 & 6.1 & 7.6 & 8.7 & 9.1 & 9.7 & 11.5 & 11.5 & 17.3 & 17.1 & 74.8 & 231.9 & 306.8 \\
\hline Interest & 3.8 & 3.7 & 4.0 & 3.9 & 3.9 & 3.8 & 3.8 & 3.7 & 3.6 & 3.5 & 3.0 & 1.5 & 37.8 & 34.7 & 72.5 \\
\hline Debt service after revised HIPC assistance & 1.2 & 1.7 & 2.6 & 2.8 & 3.0 & 3.2 & 3.4 & 4.0 & 5.4 & 6.7 & 8.2 & 16.4 & 33.9 & 128.9 & 162.8 \\
\hline Savings on debt service to IDA after revision $2 /$ & 5.7 & 8.1 & 8.4 & 10.1 & 11.5 & 12.6 & 13.0 & 13.5 & 15.3 & 15.2 & 20.5 & 18.8 & 113.4 & 269.2 & 382.6 \\
\hline
\end{tabular}

Source: IDA staff estimates.

1/ Enhanced HIPC assistance proposed to be delivered over 23 years through relief on debt service falling due to IDA on credits outstanding at end-1999.

2/ Subject to Board approval. 
Table 14. Nicaragua: Delivery of IMF Assistance under the HIPC Initiative 1/

(In millions of SDRs, unless otherwise indicated)

\begin{tabular}{|c|c|c|c|c|c|c|c|c|c|c|}
\hline & 2000 & 2001 & 2002 & 2003 & 2004 & 2005 & 2006 & 2007 & 2008 & 2009 \\
\hline Delivery schedule of IMF assistance (in percent of total assistance) & 0.0 & 0.0 & 1.0 & 3.0 & 5.5 & 20.5 & 20.5 & 20.5 & 19.5 & 9.5 \\
\hline Debt service due on IMF obligations $2 /$ & 2.5 & 5.3 & 5.0 & 6.9 & 13.2 & 20.2 & 20.2 & 20.1 & 18.3 & 10.0 \\
\hline Of which: Principal & 2.0 & 4.0 & 4.0 & 5.7 & 11.9 & 19.0 & 19.0 & 19.0 & 17.3 & 9.2 \\
\hline Interest & 0.5 & 1.3 & 1.0 & 1.2 & 1.3 & 1.2 & 1.1 & 1.0 & 0.9 & 0.9 \\
\hline \multicolumn{11}{|l|}{ IMF assistance--deposits into Nicaragua's account } \\
\hline Interim assistance & $\ldots$ & $\ldots$ & 1.9 & 0.7 & $\ldots$ & $\ldots$ & $\ldots$ & $\ldots$ & $\ldots$ & $\ldots$ \\
\hline Completion point assistance & $\ldots$ & $\ldots$ & $\ldots$ & $\ldots$ & $61.0 / 3$ & $\ldots$ & $\ldots$ & $\ldots$ & $\ldots$ & $\ldots$ \\
\hline IMF assistance under the HIPC Initiative--drawdown schedule 4/ & 0.0 & 0.0 & 0.7 & 1.9 & 6.9 & 19.4 & 19.3 & 14.9 & 13.6 & 6.6 \\
\hline Of which: IMF assistance without interest & 0.0 & 0.0 & 0.7 & 1.9 & 3.5 & 13.0 & 13.0 & 13.0 & 12.4 & 6.0 \\
\hline Estimated interest eamings & 0.0 & 0.0 & 0.0 & 0.0 & 3.4 & 6.4 & 6.2 & 1.8 & 1.2 & 0.6 \\
\hline Debt service due on IMF obligations after IMF assistance 5/ & 2.5 & 5.3 & 4.3 & 5.0 & 6.2 & 0.8 & 0.9 & 5.2 & 4.7 & 3.4 \\
\hline \multicolumn{11}{|l|}{ Share of debt service due on current IMF obligations covered by } \\
\hline IMF assistance (in percent) 4/ & 0.0 & 0.0 & 13.4 & 27.3 & 52.7 & 96.0 & 95.6 & 74.1 & 74.3 & 66.0 \\
\hline \multicolumn{11}{|l|}{ Proportion of each principal repayment nbligation falling due during the period to be paid } \\
\hline by HIPC Initiative assistance from the principal deposited in Nicaragua's account 6/ & 0.0 & 0.0 & 33.2 & 33.2 & 29.5 & 68.5 & 68.5 & 68.5 & 71.4 & 65.7 \\
\hline & \multicolumn{10}{|c|}{ (In millions of U.S. dollars) } \\
\hline \multicolumn{11}{|l|}{ Memorandun items: } \\
\hline Total debt service due $7 /$ & 319 & 399 & 360 & 313 & 298 & 315 & 314 & 314 & 298 & 303 \\
\hline Share of total debt service covered by IMF assistance (in percent) $4 /$ & 0.0 & 0.0 & 0.2 & 0.6 & 2.3 & 6.2 & 6.1 & 4.7 & 4.6 & 2.2 \\
\hline Debt service due on IMF obligations after IMF assistance $4 /$ & 3.3 & 6.7 & 5.6 & 6.7 & 8.7 & 1.1 & 1.2 & 7.2 & 6.5 & 4.7 \\
\hline (in percent of exports) & 0.3 & 0.7 & 0.6 & 0.7 & 0.9 & 0.1 & 0.1 & 0.6 & 0.5 & 0.3 \\
\hline
\end{tabular}

Sources: Nicaraguan authorities; and Bank-Fund staff estimates.

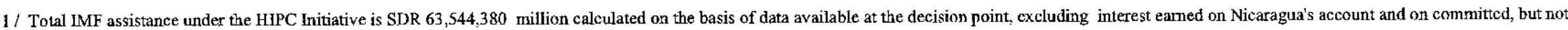
yet disbursed, as described in footnote 4 .

2/ Forthcoming obligations estimated based on rates and principal schedules in effect as of August 2000. Interest obligations include net SDR charges and assessments.

3/ A final disbursement of SDR 60,991,716 (plus accrued interest) assumed to be disbursed into Nicaragua's account at the completion point in January 2004, which is reflected in the calculation of interest.

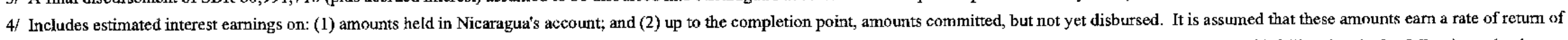

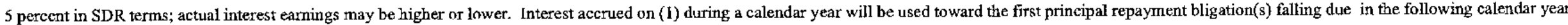

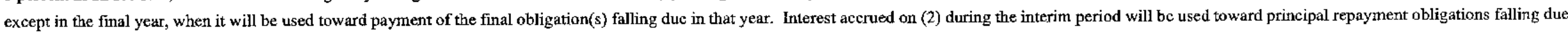
during the three years after the completion point.

5/ Total obligations less HIPC Initiative assistance.

6/ The proportion for 2002 applies nnly to the principal repayment obligation that fell due in December, as approved by the Board.

$7 /$ After traditional debt relief mechanisms. 
Table 15. Nicaragua: Paris Club Creditors' Delivery of Debt Relief Under Bilateral Initiatives Beyond the Enhanced HIPC Initiative

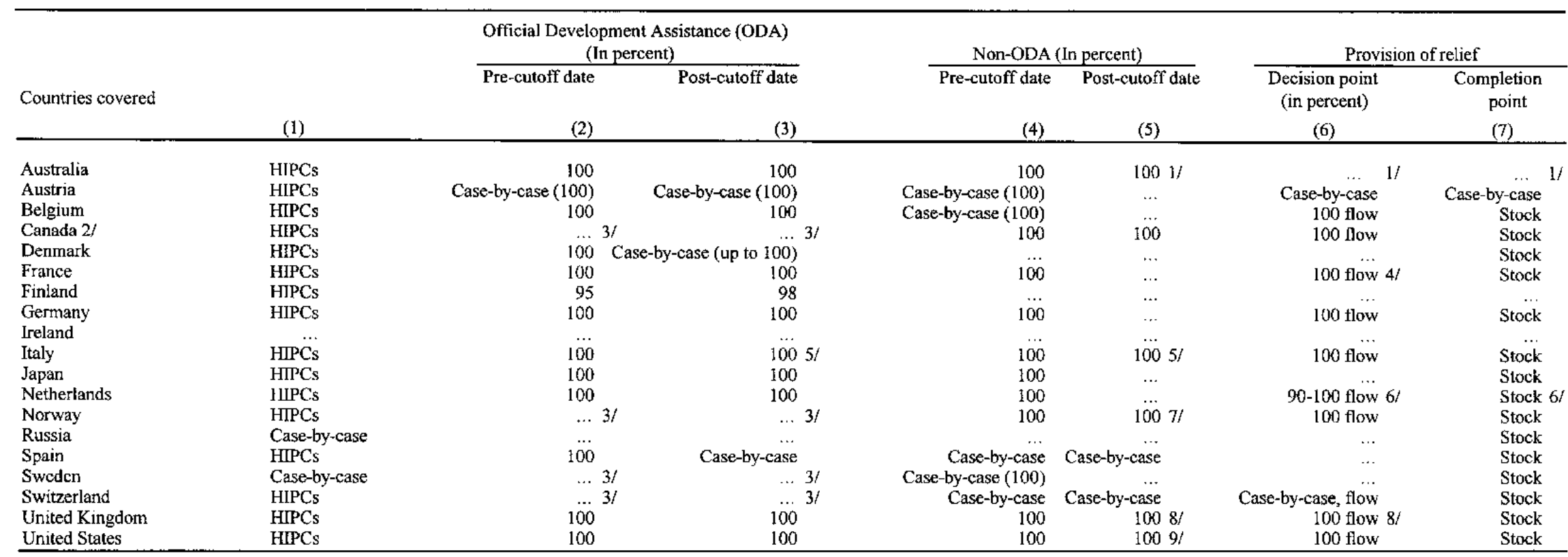

Source: Paris Club Secretariat.

Note: Columns (1) to (7) describe the additional debt relief provided following a specific methodology under bilateral initiatives and need to be read as a whole for each creditor. In column (1), "HIPCs" stands for eligible countries effectively qualifying for the HIPC Initiative process. A "100 percent" mention in the table means that the debt relief provided under the enhanced lШPC Initiative framework witl be topped up to 100 percent through a bilateral initiative.

1/ Australia: post-cutoff-date non-ODA relief to apply to debts incurred before a date to be finalized; timing details for both flow and stock relief are to be finalized.

2/ Canada including Bangladesh. Canada has granted a moratorium of debt service as of January 2001 on all debt disbursed before end-March 1999 for 11 out of 17 HIPCs with debt service due to Canada The debt will be written off at the completion point The countries to be covered are Benin, Bolivia Cameroon, Ethiopia, Guyana, Honduras, Madagascar Mali, Senegal, Tanzania and Zamhia 3/ 100 percent of ODA claims have aiready been cancelled on HIPCs, with the exception of Myanmar's debt to Canada.

3/ 100 percent of ODA claims have aiready been cancelled on on ODA claims will go to a special account and will be used for specific development projects. on ODA claims will go to a special account and will be used for specific development projects.
5/ Italy: cancellation of 100 percent of all debts (pre- and post-cutoff-dates, ODA and non-ODA) incurred before June 20, 1999 (the Cologne summit). At decision point cancellation of the related amounts

falling due in the interim period. At completion point cancellation of the stock of remaining debt.

6/ The Netherlands: 100 percent ODA: pre- and post-cutoff-date debt will be cancelled at decision point; for non-ODA: in some particular cases (Bolivia, Burkina Faso, Mali, Ethiopia, Nicaragua,

and Tanzania), the Netherlands will write off 100 percent of the consolidated amounts on the flow at decision point; all other HIPCs will receive interim relief up to 90 percent reduction of the consolidated amounts. At completion point, all HIPC countries will receive 100 percent cancellation of the remaining stock of the pre-cutoff-date debt.

7/ On dcbt assumed before December 31, 1997.

8/ United Kingdom: "beyond 100 percent" full write-off of all debts of HIPCs as of their decision points, and reimbursement at the decision point of any debt service paid before the decision point.

9/ United States: 100 percent post-cutoff-date non-ODA treated on debt assumed prior to 06/20/99 (the Cologne summit) 
Table 16. Nicaragua: HIPC Initiative: Status of Country Cases Considered Under the Initiative, as of December 2003

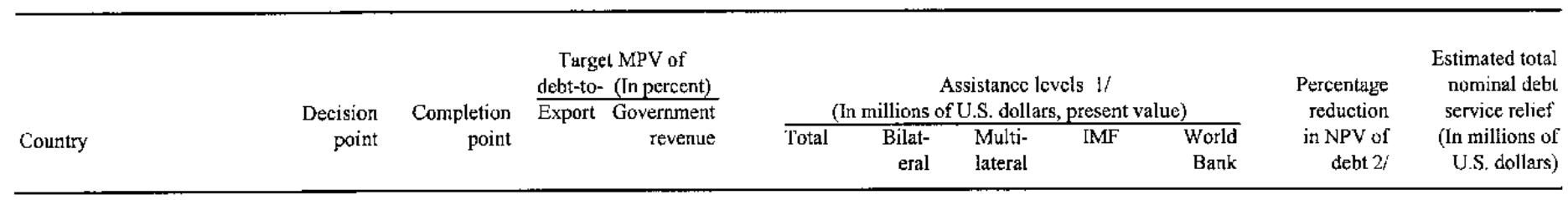

(Completion point reached under enhanced framcwork)

\begin{tabular}{|c|c|c|c|c|c|c|c|c|c|c|c|}
\hline & & & & & & \\
\hline Benin & Jul. 00 & Apr. 03 & 150 & & 265 & 77 & 189 & 24 & 84 & 31 & 460 \\
\hline Bolivia & & & & $\ldots$ & 1,302 & 425 & 876 & 84 & 194 & $\ldots$ & 2,060 \\
\hline Original framework & Sep. 97 & Sep. 98 & 225 & & 448 & 157 & 291 & 29 & 54 & 14 & 760 \\
\hline Enhanced framework & Feb. 00 & Jun. 01 & 150 & $\ldots$ & 854 & 268 & 585 & 55 & 140 & 30 & 1,300 \\
\hline Burkina Faso & & & & $\ldots$ & 553 & 83 & 469 & 58 & 231 & $\ldots$ & 930 \\
\hline Original framework & Sep 97 & Jul. 00 & 205 & & 229 & 32 & 196 & 22 & 91 & 27 & 400 \\
\hline Enhanced framework & Jul. 00 & Apr. 02 & 150 & $\ldots$ & 195 & 35 & 161 & 22 & 79 & 30 & 300 \\
\hline Topping up & & Apr. 02 & 150 & $\ldots$ & 129 & 16 & 112 & 14 & 61 & $\ldots$ & 230 \\
\hline Guyana & & & & & 591 & 223 & 367 & 74 & 68 & $\ldots$ & 877 \\
\hline Original framework & Dec. 97 & May 99 & 107 & 280 & 256 & 91 & 165 & 35 & 27 & 24 & 440 \\
\hline Enhanced framcwork & Nov, 00 & Dec. 03 & 150 & 250 & 335 & 132 & 202 & 40 & 41 & 40 & 437 \\
\hline Mali & & & & $\ldots$ & 538 & 169 & 369 & 59 & 187 & & 895 \\
\hline Original framework & Sep. 98 & Sep. 00 & 200 & & 121 & 37 & 84 & 14 & 44 & 9 & 220 \\
\hline Enhanced framewotk & Sep. 00 & Feb. 03 & 150 & $\ldots$ & 417 & 132 & 285 & 45 & 143 & 29 & 675 \\
\hline Mauritania & Feb. 00 & Jun. 02 & 137 & $\ldots$ & 622 & 261 & 361 & 47 & 100 & 50 & 1,100 \\
\hline Mozambiquc & & & & 250 & 2,023 & 1,270 & 753 & 143 & 443 & $\ldots$ & 4,300 \\
\hline Original framework & Apr. 98 & Jun. 99 & 200 & & 1,717 & 1,076 & 641 & 125 & 381 & 63 & 3,700 \\
\hline Enhanced framework & Apr. 00 & Sep. $0 !$ & 150 & $\ldots$ & 306 & 194 & 112 & 18 & 62 & 27 & 600 \\
\hline Tanzania & Apr. 00 & Nov. 01 & 150 & $\ldots$ & 2,026 & 1,006 & 1,020 & 120 & 695 & 54 & 3,000 \\
\hline Uganda & & & & $\ldots$ & 1,003 & 183 & 820 & 160 & 517 & $\ldots$ & 1,950 \\
\hline Original framework & Apr. 97 & Apr. 98 & 202 & & 347 & 73 & 274 & 69 & 160 & 20 & 650 \\
\hline Enhanced framework & Feb. 00 & May 00 & 150 & $\ldots$ & 656 & 110 & 546 & 91 & 357 & 37 & 1,300 \\
\hline & & & (Dec & int rez & under o & nced fra & vork) & & & & \\
\hline Cameroon & Oct 00 & Floating & 150 & $\ldots$ & 1,260 & 874 & 324 & 37 & 179 & 27 & 2,000 \\
\hline Chad & May, 01 & Floating & 150 & $\ldots$ & 170 & 35 & 134 & 18 & 68 & 30 & 260 \\
\hline Congo, Dem. Rep. of & Jul. 03 & Floating & 150 & $\ldots$ & 6,311 & 3,837 & 2,474 & 472 & 831 & 80 & 10,389 \\
\hline Ethiopia & Nov. 01 & Floating & 150 & $\ldots$ & 1,275 & 482 & 763 & 34 & 463 & 47 & 1,930 \\
\hline Gambia, The & Dec. 00 & Floating & 150 & $\ldots$ & 67 & 17 & 49 & 2 & 22 & 27 & 90 \\
\hline Ghana & Feb. 02 & Floating & 69 & 250 & 2,186 & 1,084 & 1,102 & 112 & 781 & 56 & 3,700 \\
\hline Guinea & Dec. 00 & Floating & 150 & $\ldots$ & 545 & 215 & 328 & 31 & 152 & 32 & 800 \\
\hline Guinea-Bissau & Dec. 00 & Floating & 150 & $\ldots$ & 416 & 212 & 204 & 12 & 93 & 85 & 790 \\
\hline Honduras & Jul. 00 & Floating & 110 & 250 & 556 & 215 & 340 & 30 & 98 & 18 & 900 \\
\hline Madagascar & Dec. 00 & Floating & 150 & $\ldots$ & 814 & 457 & 357 & 22 & 252 & 40 & 1,500 \\
\hline Malawi & Dec. 00 & Floating & 150 & $\ldots$ & 643 & 163 & 480 & 30 & 331 & 44 & 1,000 \\
\hline Nicaragua & Dec. 00 & Floating & 150 & $\ldots$ & 3,267 & 2,145 & 1,123 & 82 & 189 & 72 & 4,500 \\
\hline Niger & Dec. 00 & Floating & 150 & $\ldots$ & 521 & 211 & 309 & 28 & 170 & 54 & 900 \\
\hline Rwanda & Dec. 00 & Floating & 150 & $\ldots$ & 452 & 56 & 397 & 44 & 228 & 71 & 800 \\
\hline Sāo Tomé and Príncipe & Dec. 00 & Floating & 150 & $\ldots$ & 97 & 29 & 68 & - & 24 & 83 & 200 \\
\hline Senegal & Jun 00 & Floating & 133 & 250 & 488 & 193 & 259 & 45 & 124 & 19 & 850 \\
\hline Sierra Leone & Mar. 02 & Floating & 150 & $\ldots$ & 600 & 268 & 332 & 123 & 122 & 80 & 950 \\
\hline Zambia & Dec. 00 & Floating & 150 & $\ldots$ & 2,499 & 1,168 & 1,331 & 602 & 493 & 63 & 3,850 \\
\hline
\end{tabular}

(Decision point reached under original framework)

\begin{tabular}{lccccccccccccc} 
Côte d'lvoite & Mar. 98 & $\ldots$ & 141 & 280 & 345 & 163 & 182 & 23 & 91 & & 6 & $3 /$ & \\
$\begin{array}{l}\text { Total assistance } \\
\text { Providedicommitted }\end{array}$ & n.a. & n.a. & n.a. & n.a. & 31,434 & 15,522 & 15,780 & 2,517 & $4 /$ & 7,231 & & $\ldots$ & 51,781 \\
\hline
\end{tabular}

Sources: IMF and World Bank Board decisions; completion point documents; decision point documents; prcliminary HIPC documents; and Bank-Fund staff calculations.

1/ Assistance levels are at countries' respective decision or completion points, as applicable.

2/ In percent of the net present value (NPV) of debt at the decision or completion point (as applicable), after the full use of traditional debt-relief mechanisms.

3/ Nonreschedulable debt to non-Paris Club official bilateral creditors and the London Club, which was already subject to a highly concessional restructuring, is excluded from the $\mathrm{N}^{\mathrm{PV}}$ of dcbt at the completion point in the calculation of this ratio.

4/ Equivalent to SDR 2,024 million at an SDR/U.S. dollar exchange rate of 0.8039 . 


\section{NiCARAGUA-DEBT MANAGEMENT ISSUES}

1. A number of government agencies are involved in the management of public sector debt, with the Central Bank of Nicaragua (BCN) taking the lead because of the technical and analytical expertise of its staff. The database on external debt is maintained at the BCN, which as the financial agent of the government also manages the servicing of external debt. The ministry of finance has a division charged with public sector debt management, concentrating primarily on domestic debt; the Secretariat of External Cooperation manages concessional resources, including bilateral grants; and the technical secretariat in the office of the presidency provides input on public sector debt management to the above three agencies. The public debt law passed in 2003 (Law No. 477) provides for a technical committee (composed of representatives from the above agencies and other institutions) which is responsible for the formulation of general debt policy. This structure requires a high degree of coordination among the agencies, and at times results in duplication of responsibilities.

2. The public debt law aims, inter alia, to consolidate debt management responsibilities and to strengthen interagency coordination through the establishment of a technical committee for debt. This committee is composed of high-level officials from the ministries of finance, agriculture, external relations, and planning, the technical secretariat in the office of the presidency, the Secretariat for External Cooperation, and the $\mathrm{BCN}$. The new law also shifts the core responsibility of debt management to the ministry of finance in order to integrate public sector debt within the overall management of public resources. Given that the BCN staff charged with external debt management has acquired considerable experience and expertise in this area, it is important that the $\mathrm{BCN}$ continue to provide support and remain closely involved in debt management and debt negotiations and the maintenance of the external debt database.

3. The new law also consolidates the procedures for approval of new borrowing under the ministry of finance and the national assembly. The law provides detailed guidelines and rules on loan approval. The implementation of these procedures should ensure that external borrowing by individual government agencies and public enterprises is consistent with macroeconomic policies and conforms to the government's required degree of concessionality for such borrowing.

4. The coverage of external debt statistics is quite extensive, with the BCN maintaining information on external debt in the UNCTAD/DMFAS system. A few years ago, the $\mathrm{BCN}$ began collecting information on private sector debt on a loan-by-loan basis, and continues to monitor short-term debt flows through banking surveys.

5. Nicaragua has gone through four Paris Club operations since 1991, and has successfully negotiated debt restructuring and buyback agreements with a number of bilateral and commercial creditors. The technical team working on debt negotiations has been very involved at every step under the enhanced HIPC Initiative and should face no 
technical difficulties in negotiations or implementation of agreements with the outstanding creditors.

6. The authorities are using the software "Debt-Pro," and the technical team has carried out debt sustainability analyses and run HIPC-related scenarios. The authorities should be encouraged to strengthen further the capacity to link debt analysis to macroeconomic programming and involve debt analysis more fundamentally in economic decision making. As private sector capital inflows continue to grow and other forms of external financing become available, the integrated analysis of the country's external position (including short-term cash-flow analysis) will be crucial for a successful debt management strategy. 


\section{NiCARAGUA-MACROECONOMIC FRAMEWORK}

1. The authorities' medium- and long-term macroeconomic framework envisages sound macroeconomic policies and stable economic growth. Annual real GDP growth is projected to increase to [3.7] percent in 2004, rising to sustained growth of about 5 percent in the long term, as increasing infrastructure investment and broadened access for Nicaraguan exports improve productivity and output. Achieving sustained rapid growth will require continued structural reforms, including reforms to improve transparency and governance and to strengthen institutions. Inflation, which has been on a downward trend in recent years, is expected to be around $2 \frac{1}{2}$ percent in the long term.

\section{Achieving long-term debt sustainability in Nicaragua will require continued} fiscal consolidation. The CPS primary deficit before grants is targeted to fall to under [2] percent of GDP by 2008. Given the need to reduce the domestic debt burden this deficit will have to be financed externally and on highly concessional terms. While the external debt burden will not begin to decline substantially in NPV terms until after [2006], the nonconcessional large domestic debt will start to decline earlier. The overall debt burden, including domestic debt, is already on a downward trend. The authorities' medium-term program calls for strengthening tax administration, streamlining public expenditures, and improving public enterprise management. The authorities' civil service and pension reform plans will have an additional fiscal cost that will need to be offset by additional fiscal measures, including rationalizing current expenditure. The projections underlying the revised DSA include staff and the authorities' best estimate of the likely impact of both of these reforms. The authorities have expressed their intention to address any higher-than-estimated reform costs with further fiscal measures. The government's current investment program will wind down in the medium term, and the need for new external financing is expected to fall from 5 percent of GDP in 2003-05 to 4 percent in 2008 and below 3 percent in the long term..

\section{The current account is expected to improve in the medium term. Nicaragua's} large trade deficit is expected to improve gradually in the medium term as exports recover. Continued diversification into manufactured exports as well as rising volumes of traditional exports will be the basis for this improvement. Services receipts are also expected to rise as tourism activity converges to rates in neighboring countries. Foreign direct investment and remittances are expected to continue to rise, financing the still-large trade deficit. In the long run, improvement in the current account is limited by the increasing repatriation of profits and a tapering off of remittances growth. Continued repayment of the domestic debt and gradual improvement in the reserves position are expected to reduce external vulnerabilities and improve the outlook for the financial sector. The authorities are currently assessing long-term exchange rate policy, but in the near term they expect to maintain the current crawling peg regime. 


\section{Nicaragua-Public Sector Debt Sustainability and Creditor Negotiations}

1. Nicaragua's external debt after completion point under the enhanced HIPC Initiative will remain large. The overall debt situation has improved in recent years and is expected to continue to do so over the medium term. The authorities have made advances on both the domestic and external fronts, and have been particularly successful in recent months in their efforts to reschedule the domestic debt at longer maturities. While the domestic debt is largely nonconcessional, the nominal and net present values of the external debt is much larger, and is also a source of vulnerability.

2. Staff supports Nicaragua's effort to qualify for the completion point under the enhanced HIPC Initiative. The authorities have been diligent during the interim period in reaching agreements on debt rescheduling with all outstanding external creditors. They have signed agreements with all but one of the Paris Club creditors holding Nicaraguan debt at decision point. Negotiations with non-Paris Club official creditors have been more protracted, and are discussed in more detail below. Despite substantial progress in debt negotiations, and only moderate borrowing since decision point, Nicaragua's external debt burden remains large. Nicaragua's domestic debt burden remains substantial as well. The combination of the still-large external debt and the gradually declining domestic debt will require the government to maintain prudent fiscal policies throughout the medium term to attain debt sustainability.

3. The external debt sustainability analysis laid out in this completion point document shows that Nicaragua's external debt burden is expected to remain high throughout the medium term. This is somewhat mitigated by a substantial reduction in domestic debt, which is projected to fall by 17 percentage points of GDP during $2003-08$. Nonetheless, the large external debt burden represents a substantial source of vulnerability for the economy.

4. Of the US\$3.3 billion in assistance calculated at completion point, US\$463 million has been allocated to countries which have not yet agreed to provide, or at least agreed on modalities for provision of, HIPC assistance. Including the outstanding commercial debt, the share of external debt owed to creditors yet to provide HIPC assistance will be substantial after completion point. Discussions have begun with a number of these creditors and prospects are good for agreements with a number of official lenders. Nicaragua has ceased payments to Venezuela pending discussion of modalities of delivery of HIPC assistance. It has tried to open negotiations with Honduras on payments between electricity utilities in the two countries. Those payments have been embargoed by a Honduran utility owed money by Nicaragua. The authorities continue to await responses from Algeria, China, India, Iran, Libya, Peru, Venezuela, and the Former Federal Republic of Yugoslavia. Taiwan Province of China, despite continuing to disburse funds to Nicaragua, has refused to provide HIPC relief.

5. The government's economic and financial program recognizes this constraint. The authorities have continued to pursue bilateral agreements with official creditors, and are 
actively initiating discussions with holders of commercial debt. Finally, to ensure longerterm fiscal sustainability, the authorities plan to maintain a prudent fiscal stance over the medium term, including, inter alia, through implementation of recommendations from a recent Fund TA mission on tax reform aimed at streamlining tax collection and increasing revenues. Expenditures will also be rationalized and reform costs associated with pension and civil service reform will be contained within the envelope of resources identified in this report's medium-term macroeconomic framework. 